\title{
29. MIOCENE BENTHIC FORAMINIFERS AT SITES 794, 795, AND 797 IN THE SEA OF JAPAN WITH REFERENCE TO THE FORAM SHARP LINE IN THE HONSHU ARC ${ }^{1}$
}

\author{
Ritsuo Nomura ${ }^{2}$
}

\begin{abstract}
Benthic foraminifers from ODP Sites 794 and 797 (Yamato Basin) and Site 795 (Japan Basin) were investigated to clarify the Miocene paleoceanography and paleobathymetry of the Sea of Japan. Miocene benthic foraminifers from the three sites are generally characterized by agglutinated deep-water species apparently living below calcium carbonate compensation depth (CCD), except for faunas indicative of environments above the CCD in the early middle Miocene ( 14 to $\sim 17 \mathrm{Ma})$ and redeposited faunas in upper Miocene sediments. Based on species occurrences, the following assemblage zones are recognized from lower to upper horizons: at Site 794, the Chilostomella oolina/Cyclammina sp. C and the Spirosigmoilinella compressa/Martinottiella communis Zones; at Site 795, the Martinottiella communis, the Oridorsalis umbonatus/Cibicidoides wuellerstorfi, the Martinottiella communis/Cribrostomoides cf. crassimargo, and the Cyclammina ezoensis Zones; at Site 797, the Cyclammina sp. A/Cyclammina? sp., the Gyroidina orbicularis/Gyroidinoides planulatus, the Cibicidoides wuellerstorfi, and the Martinottiella communis/Globobulimina pupoides Zones and two barren intervals below the Cyclammina sp. A/Cyclammina? sp. Zone and between the Cibicidoides wuellerstorfi and the Martinottiella communis/Globobulimina pupoides Zones, respectively.

Benthic faunal changes are principally reflected by variations in the ratio between agglutinated and calcareous tests. Dominantly calcareous faunas developed in the early middle Miocene at Sites 794 and 797 and in the middle middle Miocene at Site 795. The first appearance of a dominantly calcareous fauna in the $G$. orbicularis/G. planulatus Zone at 17.1 Ma suggests a change from low-oxygen to high-oxygen bottom water. This paleoceanographic change was likely caused by widening of the Proto-Japan Sea in a tensional stress field. Thus, the significant opening of a basin along with the Pacific deep waters in the Sea of Japan is considered to have occurred at $17.1 \mathrm{Ma}$.

On the basis of an appearance of a barren interval and/or agglutinated fauna during the middle Miocene, two significant benthic foraminifer events are recognized in the Sea of Japan. The First Foram Sharp Line (1st FSL), representing an abrupt change from calcareous to agglutinated faunas, appears at 14.4 Ma at Site 794 and 14.3 Ma at Site 797. These ages are also close to the ages obtained for occurrence of the FSL in onshore Miocene sequences in the Honshu arc. The coeval appearance of the Ist FSL in the Yamato Basin and along the Sea of Japan coast indicates that the uplift of backbone ranges of the Honshu arc resulted in oxygen-deficient bottom water in the evolving back-arc basin. Uplift was likely associated with the clockwise rotation of the Japanese Islands. The Second Foram Sharp Line (2nd FSL) at Site 795 is estimated to occur at $11.2 \mathrm{Ma}$, which is about 3 m.y. later than the first FSL at Sites 794 and 797. These differences between the Yamato and Japan Basins suggest that sub-basins in the Sea of Japan did not respond simultaneously to changes in deep-water masses and currents. Paleotopographic features were changed dramatically through the back-arc opening process. The FSL at Site 795 may be related to global paleoceanographic changes and rather than caused by local silled basin effects. Thus, two types of the FSL are recognized in the Miocene Sea of Japan, which express both global and provincial paleoceanographic events.
\end{abstract}

\section{INTRODUCTION}

The Tertiary system along the coast of the Sea of Japan has been studied for over 60 years, both for oil exploration and for basic science. In general, the Tertiary system in the Japanese Islands is characterized by a differentiation into several basins caused by the location in an active or collision-margin setting. In order to correlate sediments among various basins, benthic foraminifers have been studied and regional zones have been proposed; e.g., Southwest Honshu (Tai, 1959), Central Honshu (Chiji, 1961), and Northeast Honshu (Matsunaga, 1963). In particular, the benthic foraminiferal zonation of Northeast Honshu is well correlated with planktonic foraminiferal zonation (Maiya, 1978). Using these biostratigraphic works, many workers have discussed the paleoenvironmental history of the coast of the Sea of Japan. Of special significance, Tai (1963, $1985,1988)$ recognized a major middle Miocene benthic foraminiferal faunal change. He defines the Foram Sharp Line (FSL), which is expressed as the abrupt change from a diversified warm-water fauna to a low-diversity agglutinated fauna. This faunal change is thought to signify one of the most important paleoceanographic changes in the development of the Sea of Japan. Because these earlier studies

\footnotetext{
'Pisciotto, K. A., Ingle, J. C., Jr., von Breymann, M. T., Barron, J., et al., 1992. Proc $O D P$, Sci. Results, 127/128, Pt. 1: College Station, TX (Ocean Drilling Program).

${ }^{2}$ Department of Earth Sciences, Faculty of Education, Shimane University, Matsue,
}

were restricted to onshore or coastal sequences, it has been possible to corroborate the FSL hypothesis in the larger Sea of Japan region.

At Sites 794, 795, and 797 a nearly continuous record of Miocene sedimentation in the Sea of Japan was recovered. Recovery of these sediments permits us to compare the sedimentation histories between the Japanese Islands and the Sea of Japan proper and to discuss paleoceanographic changes in the Sea of Japan in much more detail than heretofore possible. The objectives of this paper are to document the occurrence of Miocene benthic foraminifers at ODP Sites 794, 795 , and 797 and to discuss the FSL in relation to the opening event of the Japanese Islands (Otofuji and Matsuda, 1983, 1984; Otofuji et al., 1985a, b, c, 1986; Hamano and Tosha, 1985; Hayashida and Torii, 1988; Hayashida et al., 1991; Tamaki, 1985, 1988). Particularly, the FSL identified at Sites 794 and 797 can be correlated with geologic events identified in the Southwest Honshu arc (e.g., Nomura, 1989).

\section{MATERIALS AND METHODS}

Samples analyzed herein were taken from cores drilled during Leg 127 in order to examine the Miocene paleoceanography using benthic foraminiferal analysis. Sites 794 (2811 m present water depth) and 797 (2862 m present water depth) are both situated in the Yamato Basin (Fig. 1). Site 794 is located in the northeast Yamato Basin; Site 797 is on the base of the southern slope of the Yamato Rise. Site 795 (3298 $\mathrm{m}$ present water depth) is located in the northernmost Japan Basin (Fig. 1). 


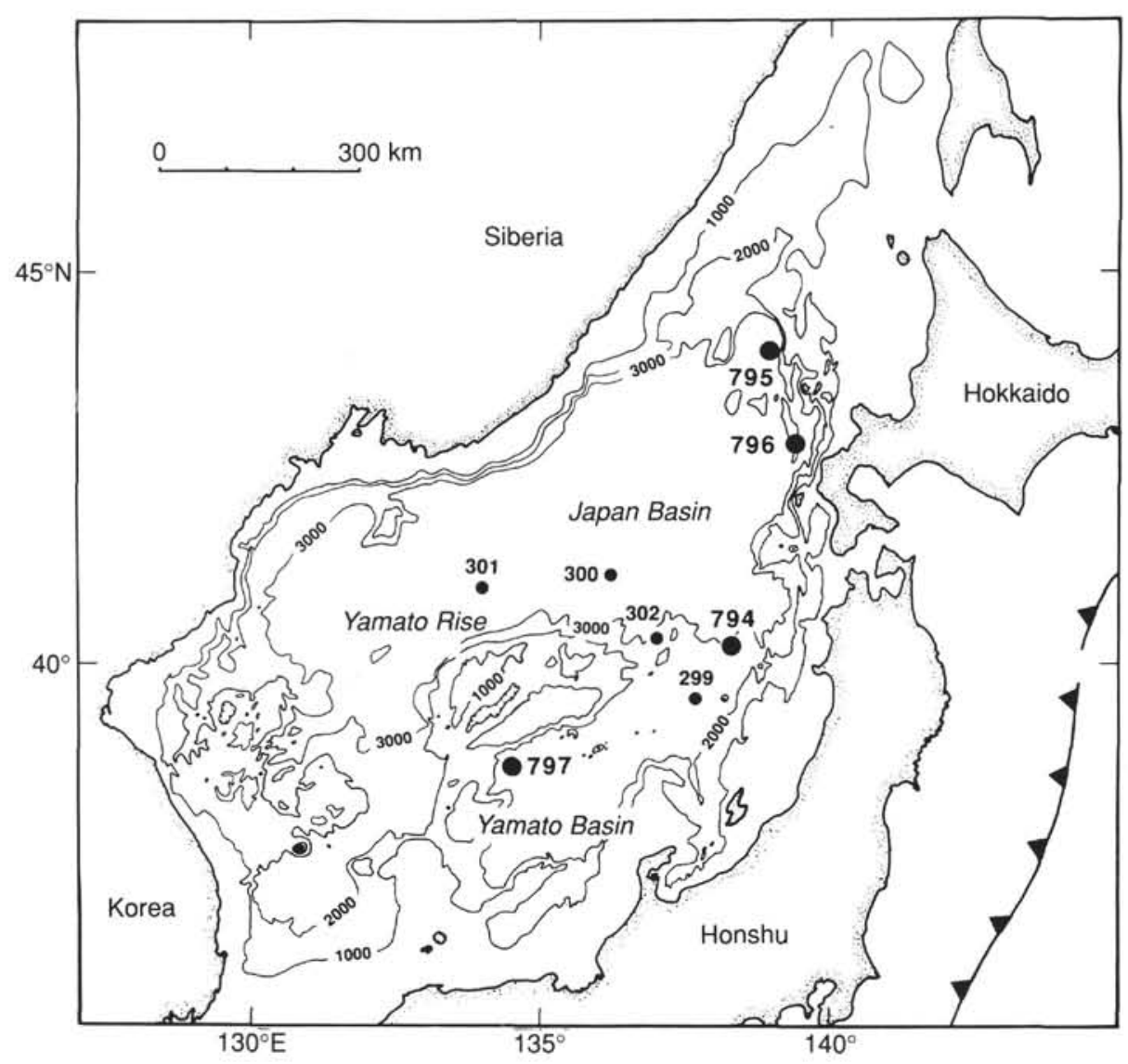

Figure 1. Location map of Sites 794, 795, and 797 in the Sea of Japan.

Sample intervals in lower to lower middle Miocene sediments are sufficient to establish faunal changes, although the preservation of foraminiferal specimens is not good. Some agglutinated taxa such as Cribrostomoides, Cyclammina, and Eggerella are commonly deformed, and calcareous overgrowths on calcareous foraminiferal tests occur in the lower middle and middle Miocene calcareous-rich sediments. Such bad foraminiferal preservation makes it difficult to analyze stable isotopes in foraminiferal tests. In addition, foraminiferal number and species number per unit sediments $\left(\mathrm{cm}^{3}\right)$ are generally low, which also limits use of a quantitative multivariate analysis. Relative percentages of each taxon are shown in Tables $1-3$, but tubular agglutinated tests such as Bathysiphon, although common, were not counted in this study. Similarly, Martinottiella communis is characterized by a tubular test that is easily broken. However, its frequency was established by counting only the early tests with a proloculus. Sample horizons from each ODP site are shown in Figures 2-4 along with lithologies, other microfossil zones, and geologic ages as given in Tamaki, Pisciotto, Allan, et al. (1990) and Barnes (this volume).

The volume of each sample from Holes 794B, 795B, 797B, and $797 \mathrm{C}$ was first measured and then washed with warm water on a $63 \mu \mathrm{m}$ sieve. However, samples that did not easily disaggregate were dried in an oven at $70^{\circ} \mathrm{C}$, and a supersaturated $\mathrm{Na}_{2} \mathrm{SO}_{4}$ solution and naphtha was applied to aid breakdown. The latter two methods are alternately applied; first the samples were bathed in supersaturated $\mathrm{Na}_{2} \mathrm{SO}_{4}$ solution about $1 \mathrm{hr}$ and the $\mathrm{Na}_{2} \mathrm{SO}_{4}$ solution decanted. Samples were dried at room temperature to allow growth of $\mathrm{Na}_{2} \mathrm{SO}_{4}$ crystals for 1 or 2 days and washed again with hot water on a sieve.
Next, the hot and dried rock residues were bathed in naphtha until cool. Hot water was again poured onto the residues, and they were boiled on a hot plate for 2 or $3 \mathrm{hr}$. By these methods, most rock fragments were disaggregated, except for hard siliceous rocks and calcareous concretions.

Benthic foraminifers were picked from the $149 \mu \mathrm{m}$ size fraction. Sample size varies from 1 to 319 specimens. A cluster analysis based on Dice's coefficient $(=\mathrm{c} / \mathrm{a}+\mathrm{b})$ was used to compare sample similarity, where $\mathrm{a}$ and $\mathrm{b}$ are the number of species in each of the two samples being compared and $\mathrm{c}$ is the number of species that occur concurrently in both samples.

\section{LITHOSTRATIGRAPHY}

Variations in Miocene benthic foraminiferal faunas correspond directly to lithological divisions. Specifically, abundances of calcareous or agglutinated foraminifers are stratigraphically well correlated with the carbonate content of sediments. The lithological units discussed below are distinguished in the Miocene sediments at Sites 794, 795 , and 797 on the basis of mineralogy, grain size, microfossil abundance, and bedding characteristics (Tamaki, Pisciotto, Allan, et al., 1990).

At Site 794, four lithological units are recognized: Unit II (Subunit IIA, 92.3-216.9 mbsf; Subunit IIB, 216.9-293.5 mbsf) consists of diatom clay and diatom ooze; Unit III (Subunits IIIA, 293.5-351.3 mbsf; Subunit IIIB, 347.8-491.7 mbsf) is composed of clay or claystone with silica of opal-CT; Unit IV (491.7-520.6 mbsf) is recognized by blue-gray to grayish-green or dark gray tuff, lapilli tuff, and claystone with or without 
Table 1. Benthic foraminiferal distribution (\%) at Site 794.

\begin{tabular}{|c|c|c|c|c|c|c|c|c|c|c|c|}
\hline $\begin{array}{l}\text { Holes } 794 \mathrm{~A} \text { and } 794 \mathrm{~B} \\
\text { Section } \\
\text { Interval }(\mathrm{cm})\end{array}$ & $\begin{array}{l}794 \mathrm{~A}- \\
19 \mathrm{X}-4 \\
4-8\end{array}$ & $\begin{array}{l}3 R-4 \\
84-88\end{array}$ & $\begin{array}{l}794 \mathrm{~B}- \\
19 \mathrm{R}-1 \\
82-83\end{array}$ & $\begin{array}{l}19 R-3 \\
43-45\end{array}$ & $\begin{array}{l}19 R-4 \\
37-39\end{array}$ & $\begin{array}{l}20 \mathrm{R}-1 \\
139-143\end{array}$ & $\begin{array}{l}20 R-4 \\
7-11\end{array}$ & $\begin{array}{l}24 R-1 \\
17-19\end{array}$ & $\begin{array}{l}24 \mathrm{R}-4 \\
126-129\end{array}$ & $\begin{array}{l}25 \mathrm{R}-1 \\
38-39\end{array}$ & $\begin{array}{l}26 \mathrm{R}-1 \\
24-26\end{array}$ \\
\hline $\begin{array}{l}\text { Ammodiscus concinnus } \\
\text { Ammodiscus macilentus } \\
\text { Ammodiscus sp. } \\
\text { Ammosphaeroidina? } \mathrm{sp} . \\
\text { Ammovertellina sp. }\end{array}$ & 4.0 & & $\begin{array}{l}10.1 \\
2.9 \\
1.4\end{array}$ & 5.0 & 2.6 & 6.7 & $\begin{array}{l}1.7 \\
5.1\end{array}$ & 1.2 & 2.4 & 1.7 & $\begin{array}{l}1.9 \\
1.2\end{array}$ \\
\hline $\begin{array}{l}\text { Bathysiphon spp. } \\
\text { Chilostomella oolina } \\
\text { Cribrostomoides cf. crassimargo } \\
\text { Cyclammina cancellata } \\
\text { Cyclammina pusilla }\end{array}$ & $\begin{array}{l}+ \\
4.0\end{array}$ & & + & $\begin{array}{c}+ \\
10.0\end{array}$ & 5.1 & $\begin{array}{c}+ \\
2.5 \\
10.0 \\
5.8 \\
0.8\end{array}$ & + & $\begin{array}{c}16.9 \\
3.0\end{array}$ & $\begin{array}{l}23.0 \\
2.4\end{array}$ & $\begin{array}{c}+ \\
10.5 \\
1.1 \\
1.1 \\
5.0\end{array}$ & 0.6 \\
\hline $\begin{array}{l}\text { Cyclammina sp. C } \\
\text { Cyclammina? sp. } \\
\text { Dentalina spp. } \\
\text { Eggerella bradyi } \\
\text { Eggerella sp. B }\end{array}$ & 12.0 & & & 5.0 & 38.5 & 12.5 & $\begin{array}{l}3.4 \\
7.7 \\
2.6\end{array}$ & 0.6 & $\begin{array}{l}19.8 \\
1.6\end{array}$ & $\begin{array}{l}15.5 \\
1.7\end{array}$ & $\begin{array}{l}17.4 \\
6.2\end{array}$ \\
\hline $\begin{array}{l}\text { Epistominella sp. } \\
\text { Fissurina spp. } \\
\text { Fursenkoina ishikiensis } \\
\text { Fursenkoina sp. } \\
\text { Gaudryinella? sp. }\end{array}$ & & & & & & & & & $\begin{array}{l}0.8 \\
1.6 \\
0.8\end{array}$ & $\begin{array}{l}4.4 \\
1.1\end{array}$ & \\
\hline $\begin{array}{l}\text { Globobulimina sp. } \\
\text { Globobulimina sp. indet. } \\
\text { Globocassidulina globosa (s.1.) } \\
\text { Globocassidulina sp. B } \\
\text { Gyroidina orbicularis }\end{array}$ & 8.0 & & & & & 0.8 & & 0.6 & $\begin{array}{l}2.4 \\
1.6\end{array}$ & 0.6 & \\
\hline $\begin{array}{l}\text { Gyroidina spp. } \\
\text { Gyroidinoides planulatus } \\
\text { Haplophragmoides sp. A } \\
\text { Haplophragmoides? sp. } \\
\text { Hopkinsina sp. }\end{array}$ & & & 11.6 & & & 2.5 & & 0.6 & 2.4 & $\begin{array}{l}0.6 \\
8.8 \\
1.1 \\
1.1\end{array}$ & $\begin{array}{l}6.8 \\
1.2\end{array}$ \\
\hline $\begin{array}{l}\text { Marginulina } \text { cf. glabra } \\
\text { Martinottiella communis } \\
\text { Miliolinella } \text { sp. } \\
\text { Nodosaria longiscata } \\
\text { Nodosaria sp. }\end{array}$ & 28.0 & 100.0 & 11.6 & 25.0 & 5.1 & 45.0 & 15.4 & $\begin{array}{l}1.2 \\
0.6\end{array}$ & $\begin{array}{l}5.6 \\
0.8 \\
2.4\end{array}$ & $\begin{array}{l}0.6 \\
3.3\end{array}$ & 5.0 \\
\hline $\begin{array}{l}\text { Nonionella miocenica } \\
\text { Nonionella stella } \\
\text { Nonionella? sp. } \\
\text { Nonionellina labradorica } \\
\text { Plectina? sp. }\end{array}$ & & & & & 2.6 & 2.5 & & $\begin{array}{l}1.8 \\
1.2 \\
0.6\end{array}$ & $\begin{array}{l}8.7 \\
2.4\end{array}$ & 1.7 & \\
\hline $\begin{array}{l}\text { Plectina nipponica } \\
\text { Psammosphaera compressa } \\
\text { Pullenia bulloides } \\
\text { Pullenia sp. } \\
\text { Recurvoides? sp. }\end{array}$ & & & $\begin{array}{l}8.7 \\
1.4\end{array}$ & & & & & 3.0 & 0.8 & $\begin{array}{l}3.3 \\
1.7 \\
3.3 \\
0.6\end{array}$ & 0.6 \\
\hline $\begin{array}{l}\text { Rhabdammina } \text { sp. } \\
\text { Saccammina sphaerica } \\
\text { Schizammina } \text { sp. } \\
\text { Spiroplectammina } \mathrm{sp} . \\
\text { Spirosigmoilinella compressa }\end{array}$ & & & $\begin{array}{l}+ \\
+ \\
+ \\
15.9\end{array}$ & & 10.3 & $\begin{array}{l}0.8 \\
1.7\end{array}$ & $\begin{array}{l}+ \\
+ \\
1.7\end{array}$ & 0.6 & $\begin{array}{r}0.8 \\
+ \\
2.4\end{array}$ & 1.7 & 6.8 \\
\hline $\begin{array}{l}\text { Thalmannammina cf. parkerae } \\
\text { Tosaia hanzawai } \\
\text { Trochammina? sp. } \\
\text { Uvigerina } \mathrm{cf} \text {. proboscidea } \\
\text { Uvigerina sp. }\end{array}$ & & & 4.3 & & 10.3 & & & $\begin{array}{l}9.6 \\
2.4\end{array}$ & $\begin{array}{l}1.6 \\
0.8 \\
0.8\end{array}$ & $\begin{array}{l}2.2 \\
0.6\end{array}$ & 30.4 \\
\hline Valvulineria cf. masudai & & & & & & & & & 4.0 & 1.7 & \\
\hline Miscellaneous taxa & 44.0 & & 31.9 & 55.0 & 25.6 & 8.3 & 62.4 & 56.0 & 10.3 & 25.4 & 21.7 \\
\hline
\end{tabular}



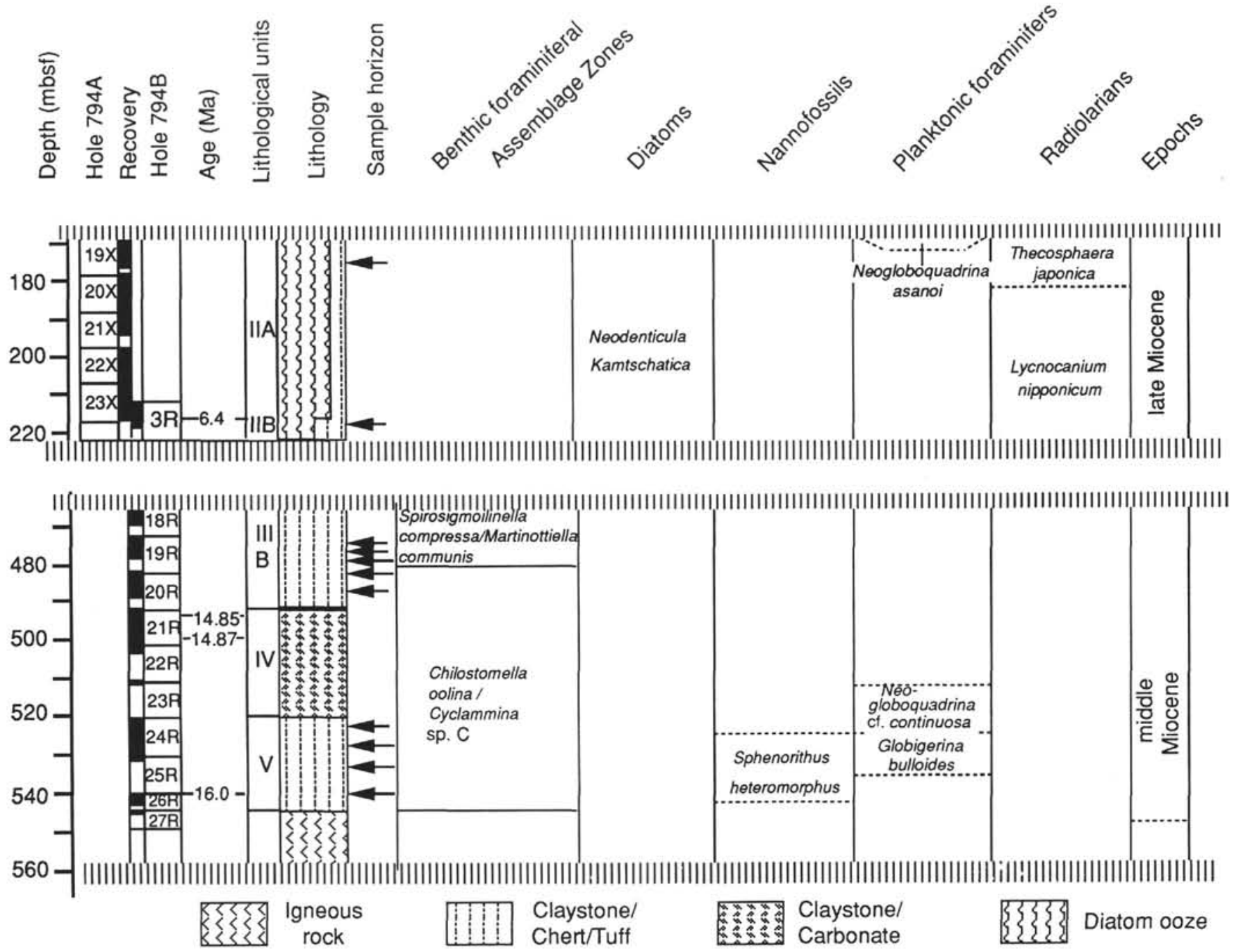

Figure 2. Sample horizons, benthic foraminiferal zones, lithological units, and diatom, nannofossil, planktonic foraminifer, and radiolarian zones at Site 794. Arrows indicate the sample horizons.

lamination and bioturbation; Unit V (520.6-544.3 mbsf) consists of moderately bioturbated claystone with glauconitic claystone and contains diagenetic dolomite and ankerite.

At Site 795, the Miocene argillaceous sediments are divided into two lithological units: Unit IV (Subunit IVA, 325-413 mbsf; Subunit IVB, 413-665 mbsf) consists of bioturbated siliceous claystone and silty siliceous claystone with chert and porcellanite; Unit V (665$685 \mathrm{mbsf}$ ) consists of claystone and altered fine to coarse-grained "blue" tuff.

At Site 797, the Miocene sediments are divided into three lithological units: Unit III (224-301.5 mbsf) includes upper upper Miocene diatom clay and siltstone; Units IV (Subunit IVA, 301.5350 mbsf; Subunit IVB, 350-426.6 mbsf) consists of upper Miocene to upper middle Miocene claystone, silty claystone, and siliceous claystone; Unit V (426.6-627.3 mbsf) consists of lower middle Miocene to lower Miocene siliceous claystone, phosphatic and calcareous claystone, and tuff; Unit VI (646.9-900.1 mbsf) consists of interbedded sandstone, siltstone, and silty claystone. Lithological Unit VI is also characterized by the alternation of volcaniclastic and carbonaceous siltstone, sandstone, and silty claystone and also interbedded with basalt.

\section{RESULTS}

Site 794

\section{Species Ranges}

Although volcanic ashes (lithological Unit IV) are intercalated in the mudstone between 491 and 520 mbsf (lithological Units V and IIIB), calcareous foraminifers such as Chilostomella oolina, Nonionella miocenica, and Globocassidulina sp. C occur almost continuously through Sample 127-794B-20R-1, 139-143 cm (483.39 mbsf) (Fig.5). Gyroidina orbicularis, Valvulineria masudai, Gyroidinoides planulatus, and Nonionella stella are rare and their occurrences are restricted to lithostratigraphic Unit V. Agglutinated foraminifers are generally long ranging. For example, Martinottiella communis is found in all samples examined at Site 794. The occurrences of Thalmannammina and Cyclammina pusilla are similar to the upper range of calcareous foraminifers.

\section{Abundance}

Abundances of the most common species at Site 794 are shown in Figure 6. Chilostomella oolina occupies over $10 \%$ of the fauna at 


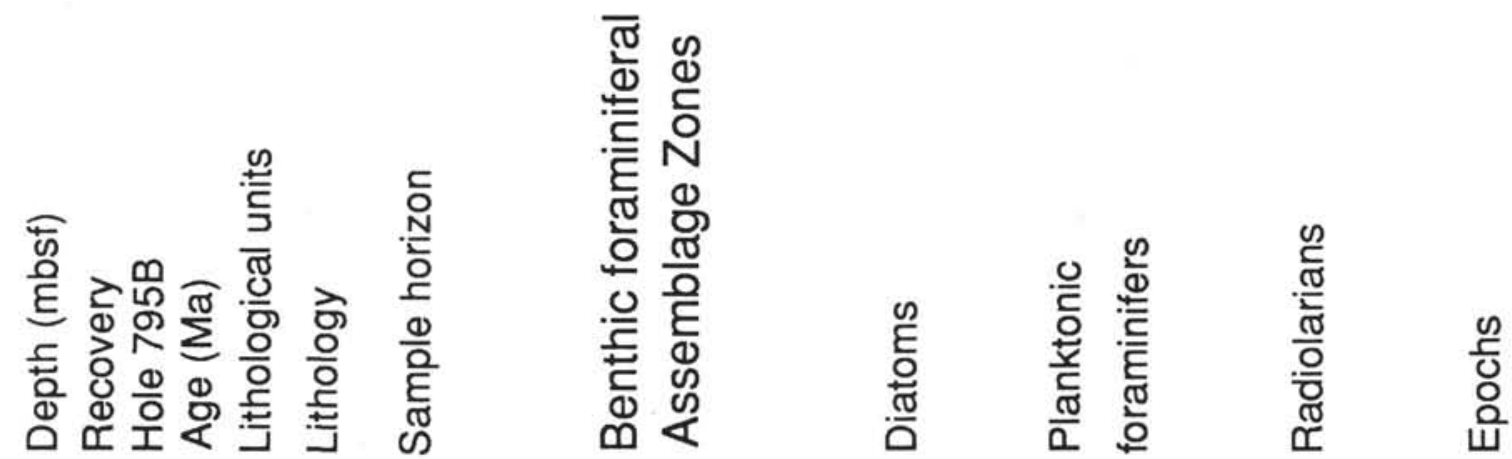

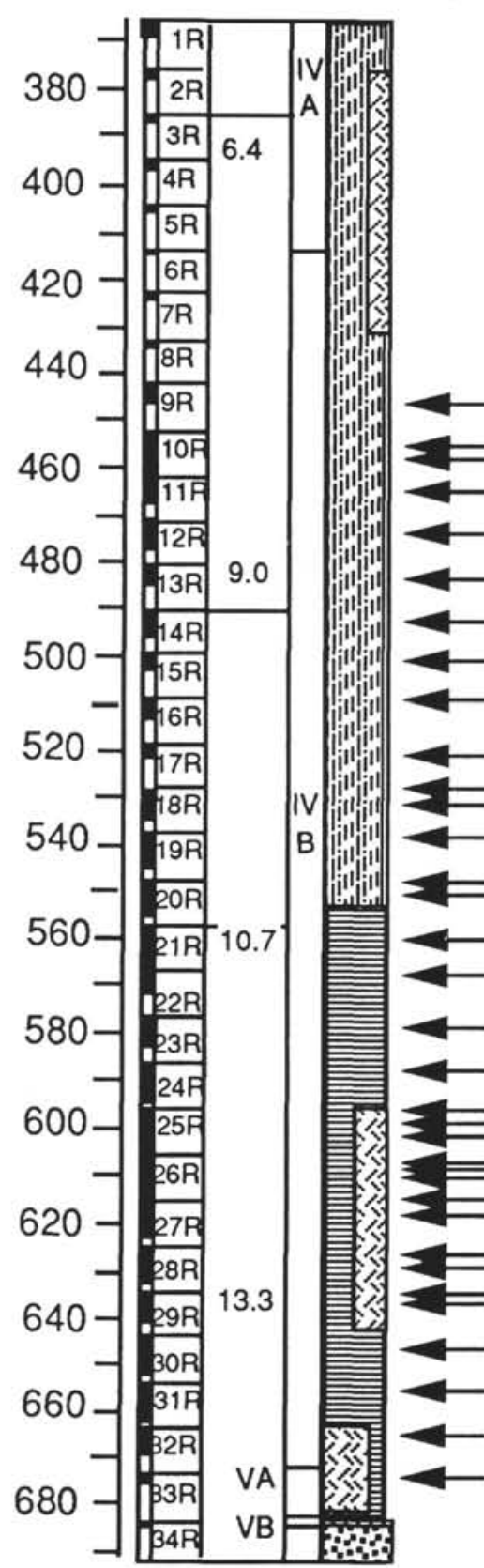

등
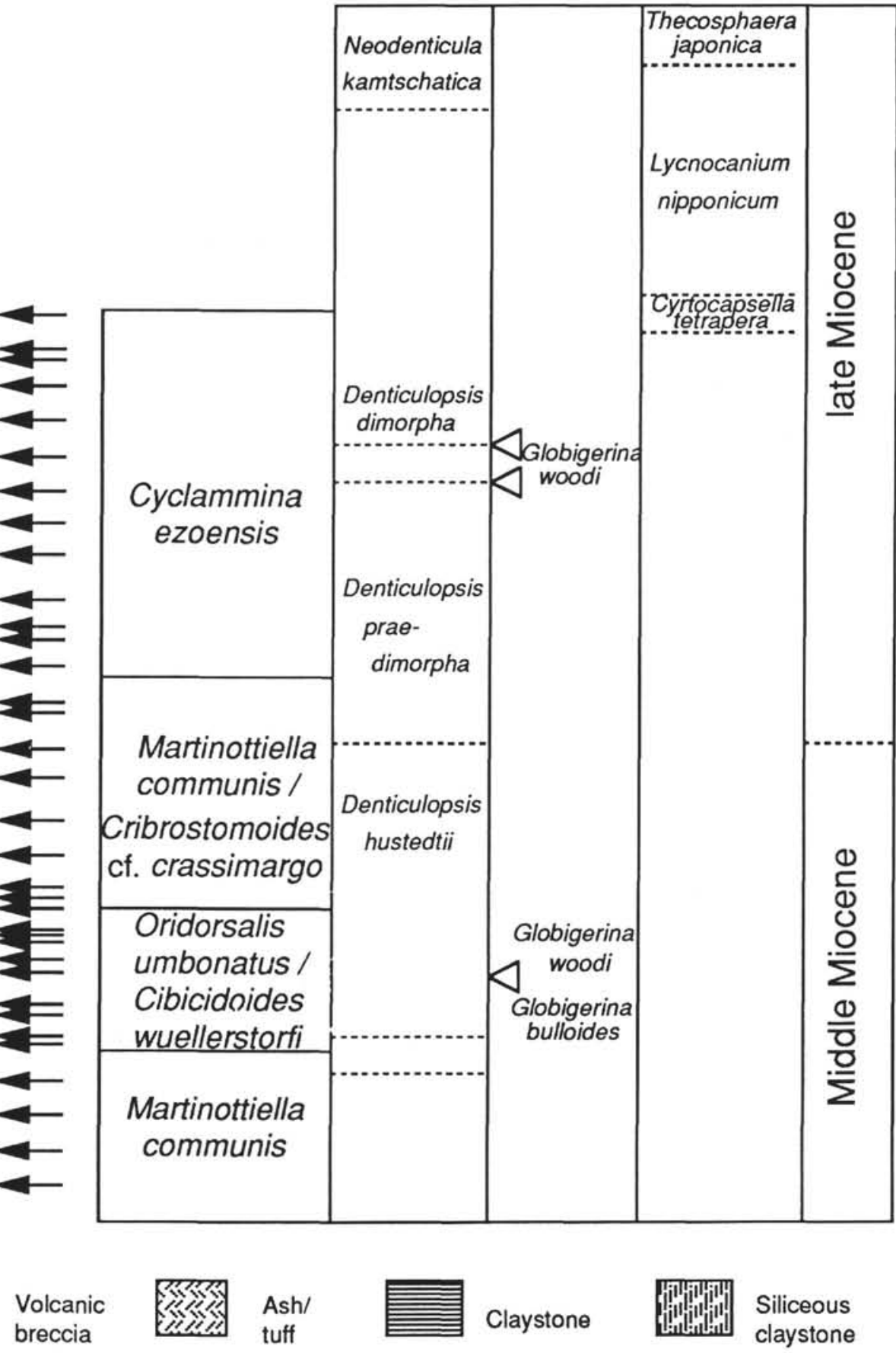

Figure 3. Sample horizons, benthic foraminiferal zones, lithological units, and diatom, nannofossil, planktonic foraminifer, and radiolarian zones at Site 795. Arrows indicate the sample horizons. 

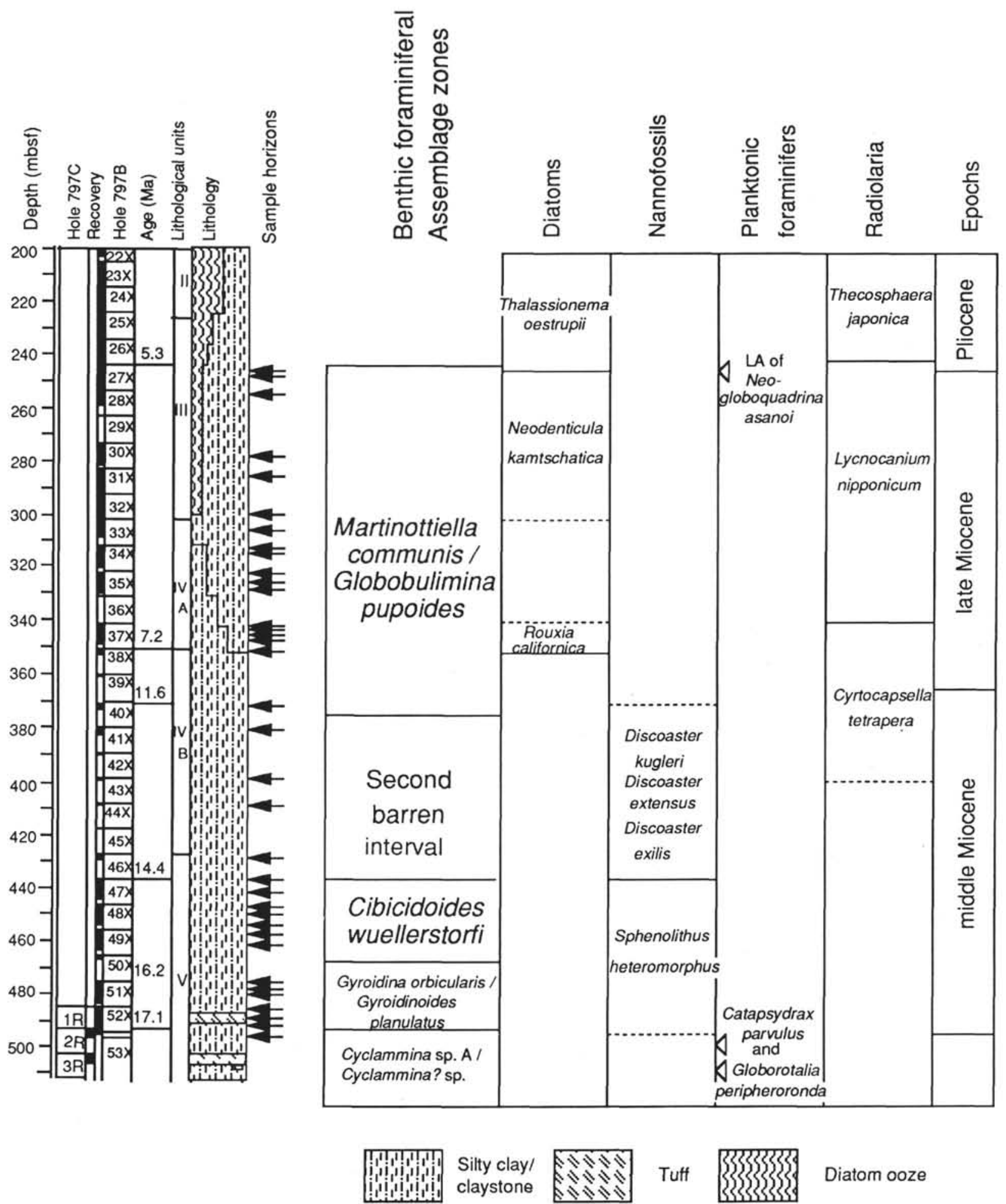

Figure 4. Sample horizons, benthic foraminiferal zones, lithological units, and diatom, nannofossil, planktonic foraminifer, and radiolarian zones at Site 797. Arrows indicate the sample horizons. 

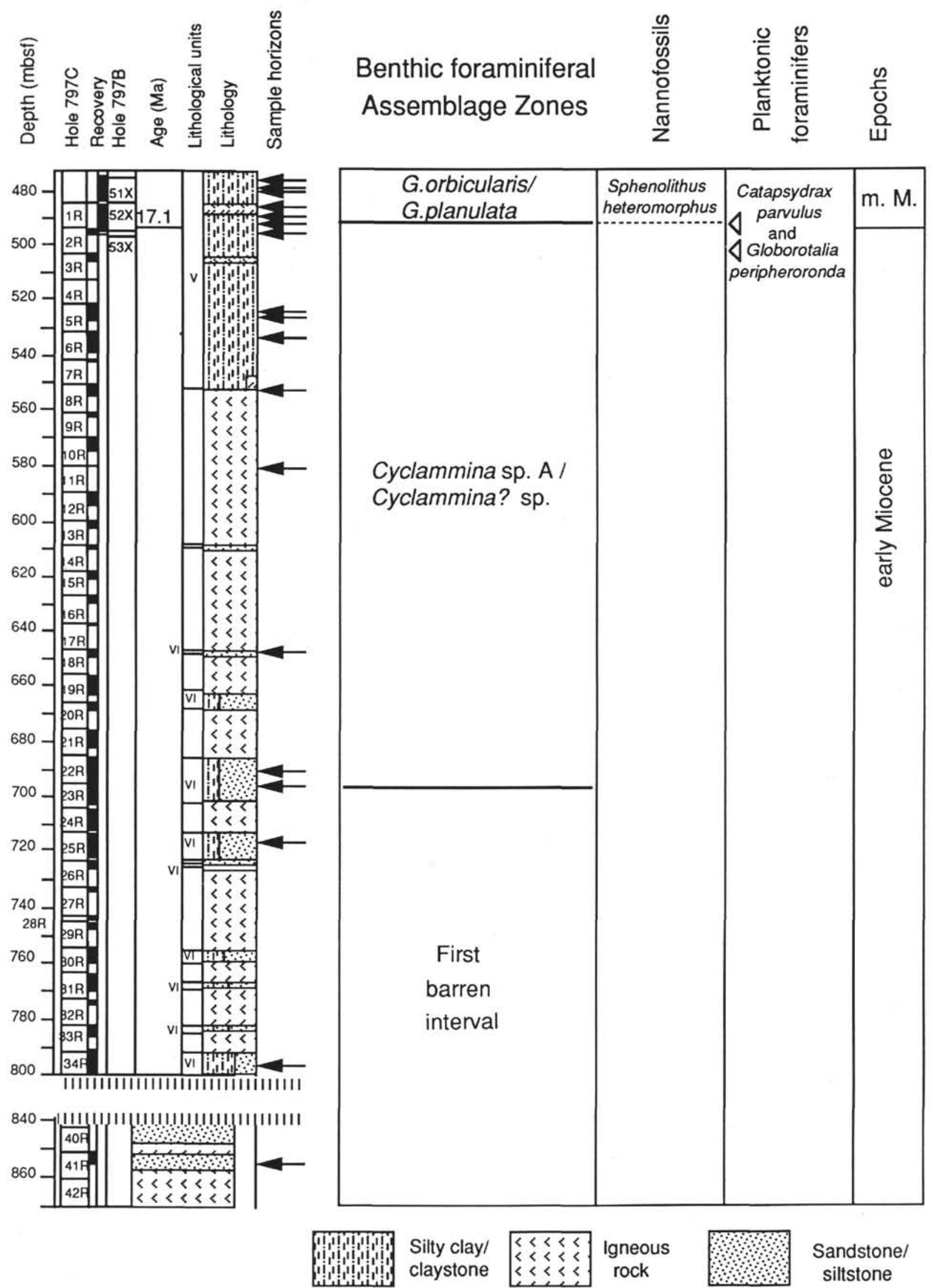

Figure 4 (continued). 
Table 2. Benthic foraminiferal distribution (\%) at Site 795.

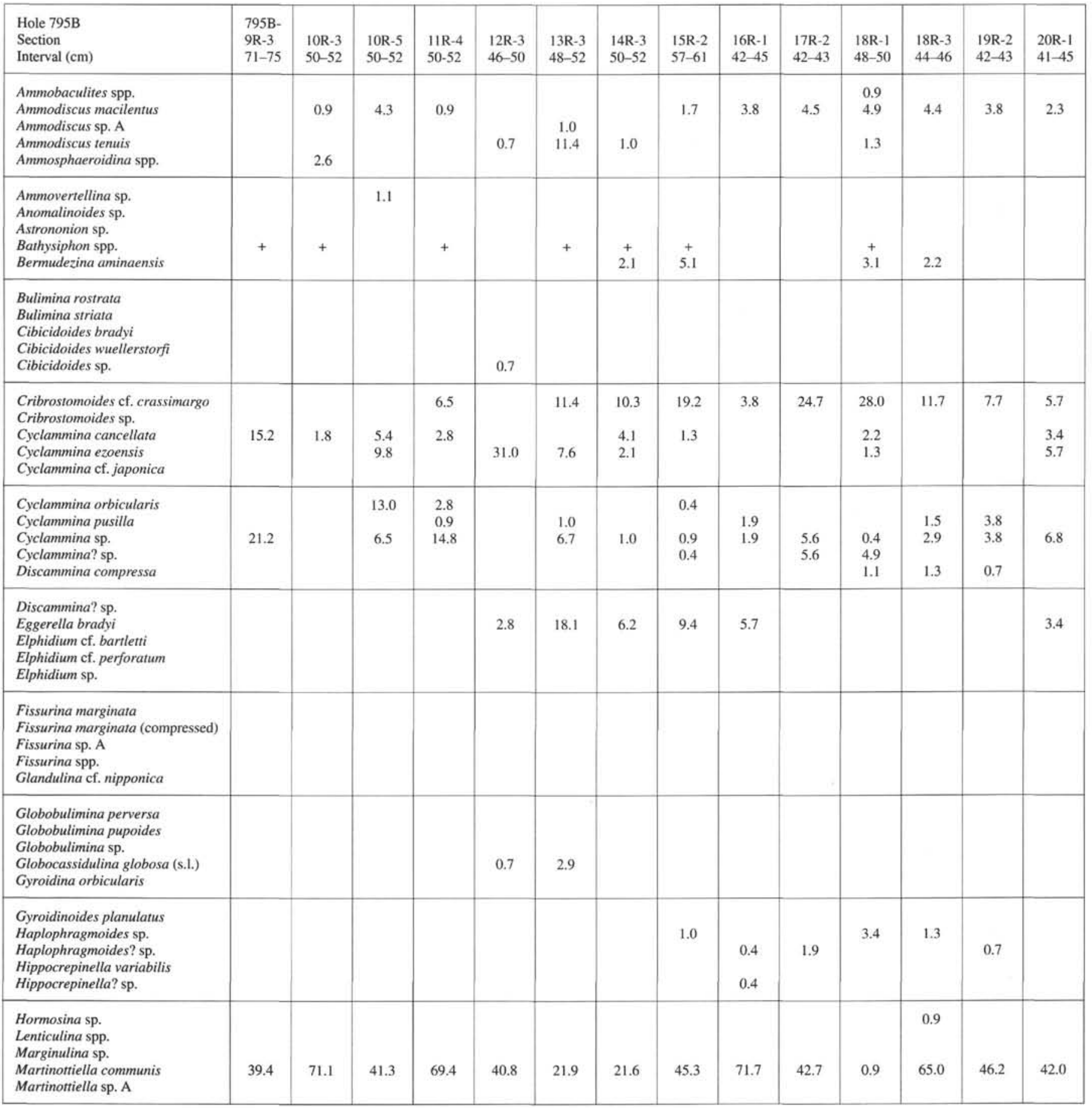

$520.77-530.68$ mbsf and attains $23 \%$ of the total fauna at Sample 127-794B-24R-4, 126-129 cm (526.36 mbsf). Cyclammina sp. and Spirosigmoilinella compressa attain peak abundances in lithological Unit IIIB, but they do not exhibit continuously high abundance through this unit. Cyclammina sp. $\mathrm{C}$ and Thalmannammina cf. parkerae are most abundant in lithological Unit V, though they are rare in some samples. The proportion of Martinottiella communis is generally high in the upper Miocene (lithological Unit II) and comprises up to $100 \%$ of the fauna; indeed upper Miocene faunas are characterized by a low number of species and individuals (0.9-1.3 species and $1.3-12.1$ individuals $/ \mathrm{cm}^{3}$ ).
Figure 7 illustrates the species number, individuals $/ \mathrm{cm}^{3}$, as well as species occurrences determined using the sedimentation rate per 1000 yr. As clearly shown in this figure, higher numbers of both foraminiferal species and individuals characterize lithological Unit V, lower numbers occurring in Units IIIB and II, particularly in Unit II.

\section{Calcareous vs. Agglutinated Foraminifers}

A distinct peak in calcareous foraminifers represented by Chilos tomella oolina is found at $526.36 \mathrm{mbsf}$, attaining $55 \%$ of the total fauna (Fig. 8). The high abundance of calcareous foraminifers 
Table 2 (continued).

\begin{tabular}{|c|c|c|c|c|c|c|c|c|c|c|c|c|c|c|}
\hline $\begin{array}{l}\text { Hole 795B } \\
\text { Section } \\
\text { Interval }(\mathrm{cm})\end{array}$ & $\begin{array}{l}795 \mathrm{~B}- \\
9 \mathrm{R}-3 \\
71-75\end{array}$ & $\begin{array}{l}10 R-3 \\
50-52\end{array}$ & $\begin{array}{l}10 R-5 \\
50-52\end{array}$ & $\begin{array}{l}11 \mathrm{R}-4 \\
50-52\end{array}$ & $\begin{array}{l}12 R-3 \\
46-50\end{array}$ & $\begin{array}{l}13 R-3 \\
48-52\end{array}$ & $\begin{array}{l}14 R-3 \\
50-52\end{array}$ & $\begin{array}{l}15 \mathrm{R}-2 \\
57-61\end{array}$ & $\begin{array}{l}16 R-1 \\
42-45\end{array}$ & $\begin{array}{l}17 R-2 \\
42-43\end{array}$ & $\begin{array}{l}18 R-1 \\
48-50\end{array}$ & $\begin{array}{l}18 R-3 \\
44-46\end{array}$ & $\begin{array}{l}19 R-2 \\
42-43\end{array}$ & $\begin{array}{l}20 \mathrm{R}-1 \\
4 \mathrm{I}-45\end{array}$ \\
\hline $\begin{array}{l}\text { Melonis nikobarense } \\
\text { Melonis pompilioides } \\
\text { Nodosaria sp. } \\
\text { Oolina sp. A } \\
\text { Oolina sp. B }\end{array}$ & & 0.9 & & & 0.7 & 1.0 & & & & & & & & \\
\hline $\begin{array}{l}\text { Pullenia bulloides } \\
\text { Pullenia quinqueloba } \\
\text { Pullenia salisburyi } \\
\text { Pyrgo sp. } \\
\text { Pyrgo? sp. }\end{array}$ & & & & & & & & & & & & & & \\
\hline $\begin{array}{l}\text { Saccammina cf. sphaerica } \\
\text { Schizammina sp. } \\
\text { Sphaeroidina japonica } \\
\text { Sphaeroidina sp. } \\
\text { Spirosigmoilinella compressa }\end{array}$ & & & + & & & & & & & & + & + & & \\
\hline $\begin{array}{l}\text { Stilostomella sp. } \\
\text { Technitella sp. } \\
\text { Textularia sp. } \\
\text { Thalmannammina cf. parkerae } \\
\text { Thalmannammina? sp. }\end{array}$ & & & & & & & 4.1 & 2.1 & & & 5.8 & & & \\
\hline
\end{tabular}

changes abruptly between Samples 127-794B-20R-4, 7-11 cm, and 127-794B-24R-1, 17-19 cm.

\section{Site 795}

\section{Species Ranges}

The stratigraphic distribution of benthic foraminifers at Site 795 is shown in Figure 9. Except for sporadic occurrences of Elphidium bartletti and Globocassidulina globosa s.l., the occurrences of calcareous foraminifers are restricted to a short interval from Sample 127-795B-29R-3, 116-120 cm (639.46 mbsf), to 795B-25R-4, 23-26 $\mathrm{cm}$ (601.43 mbsf). Among the calcareous foraminifers, Gyroidina orbicularis is long ranging at this site. Elphidium bartletti, which is believed to be a shallow faunal element of northern seas, is badly preserved and suggests downward transport of a portion of the fauna.

Agglutinated foraminifers are generally also long ranging, as shown by Cribrostomoides cf. crassimargo, Ammodiscus macilentus, and Martinottiella communis. Cyclammina pusilla, C. ezoensis, and C. cancellata occur in the late Miocene, and the occurrence of Thalmannammina $\mathrm{cf}$. parkerae extends to the upper Miocene. Spirosigmoilinella compressa occurs from lithological Unit VA, although its last or stratigraphically highest appearance is coincident with that of many calcareous taxa.

\section{Abundance}

Abundances of the most common species are shown in Figure 10. Peak abundances $(>10 \%)$ of calcareous foraminifers such as Cibicidoides wuellerstorfi, Gyroidina orbicularis, Gyroidinoides planulatus, Oridorsalis umbonatus, and Uvigerina proboscidea are restricted to the middle part of lithological Unit IVB. Uvigerina proboscidea attains $25 \%$ of the total assemblage within a restricted horizon (Sample 127-795B-28R-2, 118-119 cm; $628.38 \mathrm{mbsf}$ ).

Martinottiella communis and Eggerella bradyi consistently occur in abundance throughout middle to upper Miocene strata. Cribrostomoides $\mathrm{cf}$. crassimargo attains generally high abundance in the late Miocene. Agglutinated foraminifers are generally common at Site 795; their abundances, indicated by both individuals $/ \mathrm{cm}^{3}$ and individuals $/ \mathrm{cm}^{3} / \mathrm{k}$.y. are particularly high in the late Miocene (Fig. 11). Except for the peak interval in the middle Miocene, species numbers per cubic centimeter do not show distinct variations in Hole 795B. However, a slight increase in species number $/ \mathrm{cm}^{3} / \mathrm{k}$.y. is detected in the late Miocene.

\section{Calcareous vs. Agglutinated Foraminifers}

The relative abundance of calcareous versus agglutinated foraminifers shows an increased relationship. Relatively high abun- 
Table 2 (continued).

\begin{tabular}{|c|c|c|c|c|c|c|c|c|c|c|c|c|c|}
\hline $\begin{array}{l}\text { Hole 795B } \\
\text { Section } \\
\text { Interval (cm) }\end{array}$ & $\begin{array}{l}20 R-4 \\
41-45\end{array}$ & $\begin{array}{l}21 \mathrm{R}-3 \\
39-43\end{array}$ & $\begin{array}{l}22 R-1 \\
44-48\end{array}$ & $\begin{array}{l}23 R-2 \\
37-41\end{array}$ & $\begin{array}{l}24 R-2 \\
32-36\end{array}$ & $\begin{array}{l}25 \mathrm{R}-1 \\
33-37\end{array}$ & $\begin{array}{l}25 R-3 \\
43-46\end{array}$ & $\begin{array}{l}25 R-4 \\
23-26\end{array}$ & $\begin{array}{l}26 \mathrm{R}-2 \\
38-41\end{array}$ & $\begin{array}{l}26 \mathrm{R}-3 \\
57-61\end{array}$ & $\begin{array}{l}26 \mathrm{R}-6 \\
102-105\end{array}$ & $\begin{array}{l}27 \mathrm{R}-1 \\
114-118\end{array}$ & $\begin{array}{l}27 \mathrm{R}-3 \\
114-118\end{array}$ \\
\hline $\begin{array}{l}\text { Ammobaculites spp. } \\
\text { Ammodiscus macilentus } \\
\text { Ammodiscus sp. A } \\
\text { Ammodiscus tenuis } \\
\text { Ammosphaeroidina spp. }\end{array}$ & $\begin{array}{l}2.3 \\
0.8\end{array}$ & $\begin{array}{l}0.8 \\
1.7\end{array}$ & 0.9 & 11.8 & $\begin{array}{l}7.5 \\
1.9\end{array}$ & 2.2 & & & 0.8 & & & 0.8 & \\
\hline $\begin{array}{l}\text { Ammovertellina sp. } \\
\text { Anomalinoides sp. } \\
\text { Astrononion } \mathrm{sp} \text {. } \\
\text { Bathysiphon } \mathrm{spp} . \\
\text { Bermudezina aminaensis }\end{array}$ & + & 6.7 & + & + & + & & + & $\begin{array}{l}2.5 \\
1.3\end{array}$ & + & & + & & \\
\hline $\begin{array}{l}\text { Bulimina rostrata } \\
\text { Bulimina striata } \\
\text { Cibicidoides bradyi } \\
\text { Cibicidoides wuellerstorfi } \\
\text { Cibicidoides sp. }\end{array}$ & & & & & & & & 13.8 & 5,4 & & 5.0 & $\begin{array}{l}3.1 \\
6.1\end{array}$ & 5.6 \\
\hline $\begin{array}{l}\text { Cribrostomoides } \mathrm{cf} \text {. crassimargo } \\
\text { Cribrostomoides } \mathrm{sp} . \\
\text { Cyclammina cancellata } \\
\text { Cyclammina ezoensis } \\
\text { Cyclammina } \mathrm{cf} \text {. japonica }\end{array}$ & $\begin{array}{l}8.4 \\
6.1\end{array}$ & 3.4 & 2.7 & 8.8 & 1.9 & & 6.7 & 1.3 & 1.6 & $\begin{array}{l}2.9 \\
2.9\end{array}$ & 10.0 & $\begin{array}{l}1.5 \\
1.5 \\
3.1\end{array}$ & \\
\hline $\begin{array}{l}\text { Cyclammina orbicularis } \\
\text { Cyclammina pusilla } \\
\text { Cyclammina sp. } \\
\text { Cyclammina? sp. } \\
\text { Discammina compressa }\end{array}$ & & 1.7 & & $\begin{array}{l}5.9 \\
0.9\end{array}$ & 1.9 & 6.5 & $\begin{array}{l}3.3 \\
4.3\end{array}$ & & 4.7 & 5.7 & & 6.1 & 2.8 \\
\hline $\begin{array}{l}\text { Discammina? sp. } \\
\text { Eggerella bradyi } \\
\text { Elphidium cf. bartletti } \\
\text { Elphidium cf. perforatum } \\
\text { Elphidium sp. }\end{array}$ & $\begin{array}{l}1.1 \\
4.6 \\
0.8\end{array}$ & $\begin{array}{l}0.8 \\
8.4\end{array}$ & 12.4 & 5.9 & 5.7 & $\begin{array}{l}19.6 \\
2.2\end{array}$ & 13.3 & 7.5 & $\begin{array}{l}9.3 \\
2.3\end{array}$ & & & $\begin{array}{l}10.7 \\
5.3\end{array}$ & 2.8 \\
\hline $\begin{array}{l}\text { Fissurina marginata } \\
\text { Fissurina marginata (compressed) } \\
\text { Fissurina sp. A } \\
\text { Fissurina spp. } \\
\text { Glandulina cf. nipponica }\end{array}$ & & & & & & & 3.3 & & 0.8 & & 5.0 & $\begin{array}{l}0.8 \\
0.8\end{array}$ & \\
\hline $\begin{array}{l}\text { Globobulimina perversa } \\
\text { Globobulimina pupoides } \\
\text { Globobulimina sp. } \\
\text { Globocassidulina globosa (s.l.) } \\
\text { Gyroidina orbicularis }\end{array}$ & 0.8 & 0.8 & & & & & $\begin{array}{l}3.3 \\
3.3\end{array}$ & 7.5 & $\begin{array}{l}0.8 \\
5.4 \\
3.1\end{array}$ & & $\begin{array}{l}5.0 \\
15.0\end{array}$ & $\begin{array}{l}2.3 \\
2.3 \\
1.5 \\
7.6\end{array}$ & 2.8 \\
\hline $\begin{array}{l}\text { Gyroidinoides planulatus } \\
\text { Haplophragmoides sp. } \\
\text { Haplophragmoides? sp. } \\
\text { Hippocrepinella variabilis } \\
\text { Hippocrepinella? sp. }\end{array}$ & & 0.8 & & 0.9 & & 1.9 & $\begin{array}{l}4.3 \\
2.2\end{array}$ & 6.3 & & & & 3.1 & \\
\hline $\begin{array}{l}\text { Hormosina sp. } \\
\text { Lenticulina spp. } \\
\text { Marginulina sp. } \\
\text { Martinottiella communis } \\
\text { Martinottiella sp. A }\end{array}$ & 48.1 & 60.5 & 61.1 & 50.0 & 32.1 & 26.1 & 13.3 & $\begin{array}{c}12.5 \\
1.3\end{array}$ & $\begin{array}{c}14.7 \\
0.8\end{array}$ & $\begin{array}{l}9.3 \\
48.6\end{array}$ & 17.1 & $\begin{array}{l}0.8 \\
16.8\end{array}$ & $\begin{array}{r}2.8 \\
52.8\end{array}$ \\
\hline
\end{tabular}

dances of calcareous fauna are found within the interval of 601.43637.96 mbsf (Sample 127-795B-25R-4, 23-26 cm, to 29R-3, 116$120 \mathrm{~cm}$ ) (Fig. 12).

\section{Site 797}

\section{Species Ranges}

The stratigraphic distributions of benthic foraminifers at Site 797 are shown in Figures 13 and 14. Benthic foraminifers are rare or absent in lithological Unit VI, which includes intercalated igneous rocks; however, juvenile forms of Cyclammina cancellata, Ammovertellina, Haplophragmoides, and Ammodiscus macilentus are rarely and sporadically found in this unit. Diversified foraminifers, both calcareous and agglutinated, are developed in lithological Unit V, particularly between 436.65 and 492.5 mbsf. The lower half of this interval ( $475.41-492.5 \mathrm{mbsf})$ is characterized by high species number $/ \mathrm{cm}^{3}$, with significant occurrences of Globocassidulina sp. A, Cibicidoides sp. B, Cribrostomoides cf. crassimargo, Cyclammina pusilla, Uvigerina miocenica, and Valvulineria masudai. The first appearance of Cibicidoides wuellerstorfi is estimated to occur at 
Table 2 (continued).

\begin{tabular}{|c|c|c|c|c|c|c|c|c|c|c|c|c|c|}
\hline $\begin{array}{l}\text { Hole 795B } \\
\text { Section } \\
\text { Interval (cm) }\end{array}$ & $\begin{array}{l}20 \mathrm{R}-4 \\
41-45\end{array}$ & $\begin{array}{l}21 \mathrm{R}-3 \\
39-43\end{array}$ & $\begin{array}{l}22 \mathrm{R}-1 \\
44-48\end{array}$ & $\begin{array}{l}23 R-2 \\
37-41\end{array}$ & $\begin{array}{l}24 R-2 \\
32-36\end{array}$ & $\begin{array}{l}25 \mathrm{R}-1 \\
33-37\end{array}$ & $\begin{array}{l}25 \mathrm{R}-3 \\
43-46\end{array}$ & $\begin{array}{l}25 \mathrm{R}-4 \\
23-26\end{array}$ & $\begin{array}{l}26 \mathrm{R}-2 \\
38-41\end{array}$ & $\begin{array}{l}26 R-3 \\
57-61\end{array}$ & $\begin{array}{l}26 \mathrm{R}-6 \\
102-105\end{array}$ & $\begin{array}{l}27 \mathrm{R}-1 \\
114-118\end{array}$ & $\begin{array}{l}27 R-3 \\
114-118\end{array}$ \\
\hline $\begin{array}{l}\text { Melonis nikobarense } \\
\text { Melonis pompilioides } \\
\text { Nodosaria sp. } \\
\text { Oolina sp. A } \\
\text { Oolina sp. B }\end{array}$ & & & & & & & & 1.3 & $\begin{array}{l}0.8 \\
0.8\end{array}$ & & 10.0 & 0.8 & \\
\hline $\begin{array}{l}\text { Oolina } \mathrm{sp} . \\
\text { Oridorsalis umbonatus } \\
\text { Plectina nipponica } \\
\text { Proteonina compressa } \\
\text { Proteonina cf. compressa }\end{array}$ & 2.3 & & 1.8 & 2.9 & $\begin{array}{l}1.9 \\
3.8\end{array}$ & 2.2 & & & 14.0 & & 5.0 & $\begin{array}{l}0.8 \\
8.4 \\
0.8\end{array}$ & \\
\hline $\begin{array}{l}\text { Pullenia bulloides } \\
\text { Pullenia quinqueloba } \\
\text { Pullenia salisburyi } \\
\text { Pyrgo sp. } \\
\text { Pyrgo? sp. }\end{array}$ & & & & & & & & & 0.8 & & & $\begin{array}{l}3.1 \\
0.8 \\
1.5\end{array}$ & \\
\hline $\begin{array}{l}\text { Quadrimorphina sp. } \\
\text { Quinqueloculina sp. } \\
\text { Reophax spp. } \\
\text { Reophax? sp. } \\
\text { Rhabdammina spp. }\end{array}$ & & + & + & & & $\begin{array}{c}2.2 \\
+\end{array}$ & & $\begin{array}{l}1.3 \\
+ \\
+\end{array}$ & + & + & & + & + \\
\hline $\begin{array}{l}\text { Saccammina cf, sphaerica } \\
\text { Schizammina sp. } \\
\text { Sphaeroidina japonica } \\
\text { Sphaeroidina } \text { sp. } \\
\text { Spirosigmoilinella compressa }\end{array}$ & + & + & + & + & & + & & & $\begin{array}{l}0.8 \\
4.7\end{array}$ & & & $\begin{array}{l}0.8 \\
0.8\end{array}$ & \\
\hline $\begin{array}{l}\text { Stilostomella sp. } \\
\text { Technitella sp. } \\
\text { Textularia sp. } \\
\text { Thalmannammina cf. parkerae } \\
\text { Thalmannammina? sp. }\end{array}$ & & 0.8 & $\begin{array}{l}0.9 \\
0.8\end{array}$ & 0.9 & & & & & & $\begin{array}{l}3.1 \\
2.9\end{array}$ & $\begin{array}{l}5.0 \\
5.7\end{array}$ & & 3.8 \\
\hline $\begin{array}{l}\text { Trochammina cf. globigeriniformis } \\
\text { Trochammina? sp. } \\
\text { Uvigerina proboscidea } \\
\text { Valvulinerina sp. }\end{array}$ & $\begin{array}{l}0.8 \\
2.3\end{array}$ & & & & & & & 25.0 & $\begin{array}{l}7.8 \\
0.8\end{array}$ & & & 1.5 & \\
\hline Miscellaneous taxa & 21.8 & 13.6 & 18.7 & 12.1 & 43.4 & 37.2 & 39.1 & 12.5 & 16.1 & 24.7 & 2.1 & 6.9 & 26.7 \\
\hline
\end{tabular}

15.3 Ma in this site, which is similar to its first appearance in the open Pacific Ocean at about 15.0-14.9 Ma (Thomas and Vincent, 1987). Both calcareous and agglutinated foraminifers disappear or here interrupt occurrences in the interval between 379.34 and $426.88 \mathrm{mbsf}$; 127-797B-41X-1, 34-38 cm, to 127-797B-44X-1, 36-40 cm, which is correlative with lithological Unit IVB. However, a few specimens of Martinottiella communis are found in this latter interval.

Benthic foraminifers are again found in the upper part of lithological Units IV and III. However, some species such as Cibicidoides wuellerstorfi and Pullenia bulloides disappear within lithological Unit IVA. Gyroidinoides planulatus and Globobulimina pupoides continue to occur in upper Miocene strata.

Sample 127-797B-31X-3, 50-54 cm, contains abundant calcareous foraminifers including Buccella cf. kuromatsunaiensis, Cibicides $\mathrm{cf}$. refulgens, Elphidium cf. jenseni, E. subarcticum, Grabratella subopercularis, and $I$. helenae. In spite of the high diversity of this assemblage, the bad preservation and the inclusion of typical shallow- water species such as $G$. subopercularis, B. cf. kuromatsunaiensis, and E. cf. jenseni indicate redeposition of this fauna from shallower depths.

\section{Abundance}

Abundance of the most common species is shown in Figure 15; foraminiferal diversities and abundance/k.y. are shown in Figure 16. Both species number and individuals per cubic centimeter are generally high in lithological Unit V. Species number/ $\mathrm{cm}^{3}$ exhibits a single peak in Sample 127-797B-51X-5, 51-53 cm, whereas individuals $/ \mathrm{cm}^{3}$ form several peaks in this unit. The peak in diversity in Sample 127-797B$31 X-3,50-54 \mathrm{~cm}$, noted above suggests the influence of reworked foraminifers. Thus, with the exception of the high-diversity interval in early middle Miocene, benthic foraminifers are characterized by low diversity throughout the Miocene (Fig. 16).

Early and late Miocene foraminifers are generally characterized by high relative abundances of Cyclammina sp. A, Thalmannammina cf. parkerae, and Martinottiella communis. Specifically, the following species form peaks of relative abundance in the late Miocene: Valvulineria masudai, Pullenia bulloides, Cibicidoides sp. A, C. wuellerstorfi, and Globobulimina perversa. Although Gyroidina orbicularis and Gyroidinoides planulatus are relatively abundant in the late Miocene, they are most abundant in the early middle Miocene, characterized by calcareous foraminifers.

\section{Calcareous vs. Agglutinated Foraminifers}

High relative abundances of calcareous foraminifers are consistently found between 436.65 and 488 mbsf (Sample 127-797B-47X-1, 45-49 $\mathrm{cm}$, to $127-797 \mathrm{~B}-52 \mathrm{X}-3,50-54 \mathrm{~cm}$ ), calcareous foraminifers attaining $100 \%$ of individual faunas (Fig. 17). In addition, calcareous foramini- 
Table 2 (continued).

\begin{tabular}{|c|c|c|c|c|c|c|c|c|}
\hline $\begin{array}{l}\text { Hole 795B } \\
\text { Section } \\
\text { Interval }(\mathrm{cm})\end{array}$ & $\begin{array}{l}28 \mathrm{R}-2 \\
118-119\end{array}$ & $\begin{array}{l}28 \mathrm{R}-4 \\
117-119\end{array}$ & $\begin{array}{l}29 \mathrm{R}-2 \\
116-120\end{array}$ & $\begin{array}{l}29 \mathrm{R}-3 \\
116-120\end{array}$ & $\begin{array}{l}30 \mathrm{R}-2 \\
110-112\end{array}$ & $\begin{array}{l}31 \mathrm{R}-1 \\
112-114\end{array}$ & $\begin{array}{l}32 \mathrm{R}-1 \\
106-107\end{array}$ & $\begin{array}{l}33 \mathrm{R}-1 \\
106-109\end{array}$ \\
\hline $\begin{array}{l}\text { Ammobaculites spp. } \\
\text { Ammodiscus macilentus } \\
\text { Ammodiscus } \mathrm{sp} \text {. A } \\
\text { Ammodiscus tenuis } \\
\text { Ammosphaeroidina spp. }\end{array}$ & 8.2 & $\begin{array}{l}14.3 \\
2.0\end{array}$ & 5.1 & & 5.4 & 3.6 & $\begin{array}{l}2.2 \\
4.3 \\
1.1\end{array}$ & 1.3 \\
\hline $\begin{array}{l}\text { Ammovertellina sp. } \\
\text { Anomalinoides sp. } \\
\text { Astrononion sp. } \\
\text { Bathysiphon } \mathrm{spp} . \\
\text { Bermudezina aminaensis }\end{array}$ & + & + & & & 5.4 & 7.1 & + & + \\
\hline $\begin{array}{l}\text { Bulimina rostrata } \\
\text { Bulimina striata } \\
\text { Cibicidoides bradyi } \\
\text { Cibicidoides wuellerstorfi } \\
\text { Cibicidoides sp. }\end{array}$ & $\begin{array}{l}8.2 \\
4.9 \\
1.6\end{array}$ & $\begin{array}{l}2.0 \\
2.0 \\
6.1\end{array}$ & $\begin{array}{l}0.6 \\
1.3 \\
2.6 \\
7.1\end{array}$ & $\begin{array}{l}0.8 \\
0.8\end{array}$ & & & & \\
\hline $\begin{array}{l}\text { Cribrostomoides cf. crassimargo } \\
\text { Cribrostomoides } \mathrm{sp} \text {. } \\
\text { Cyclammina cancellata } \\
\text { Cyclammina ezoensis } \\
\text { Cyclammina cf. japonica }\end{array}$ & 1.6 & & $\begin{array}{l}3.8 \\
0.6 \\
0.6\end{array}$ & 8.5 & 8.1 & 3.6 & 4.3 & $\begin{array}{l}6.3 \\
1.3\end{array}$ \\
\hline $\begin{array}{l}\text { Cyclammina orbicularis } \\
\text { Cyclammina pusilla } \\
\text { Cyclammina sp. } \\
\text { Cyclammina? sp. } \\
\text { Discammina compressa }\end{array}$ & & 4.1 & 1.9 & 0.8 & & & $\begin{array}{l}1.1 \\
1.1\end{array}$ & \\
\hline $\begin{array}{l}\text { Discammina? sp. } \\
\text { Eggerella bradyi } \\
\text { Elphidium } \text { cf. bartletti } \\
\text { Elphidium } \text { cf. perforatum } \\
\text { Elphidium } \text { sp. }\end{array}$ & $\begin{array}{l}8.3 \\
6.6 \\
\\
4.9 \\
1.6\end{array}$ & 6.1 & $\begin{array}{l}12.8 \\
3.2\end{array}$ & 18.5 & 5.4 & 3.6 & 4.3 & 6.3 \\
\hline $\begin{array}{l}\text { Fissurina marginata } \\
\text { Fissurina marginata (compressed) } \\
\text { Fissurina sp. A } \\
\text { Fissurina spp. } \\
\text { Glandulina cf. nipponica }\end{array}$ & 1.6 & 2.0 & 0.6 & & & & & \\
\hline $\begin{array}{l}\text { Globobulimina perversa } \\
\text { Globobulimina pupoides } \\
\text { Globobulimina sp. } \\
\text { Globocassidulina globosa (s.l.) } \\
\text { Gyroidina orbicularis }\end{array}$ & & 2.0 & $\begin{array}{l}1.3 \\
2.6\end{array}$ & & & & & \\
\hline $\begin{array}{l}\text { Gyroidinoides planulatus } \\
\text { Haplophragmoides } \mathrm{sp} . \\
\text { Haplophragmoides? sp. } \\
\text { Hippocrepinella variabilis } \\
\text { Hippocrepinella? sp. }\end{array}$ & 13.1 & 8.2 & 1.3 & & & & & 1.1 \\
\hline $\begin{array}{l}\text { Hormosina sp. } \\
\text { Lenticulina spp. } \\
\text { Marginulina sp. } \\
\text { Martinottiella communis } \\
\text { Martinottiella sp. A }\end{array}$ & 23.0 & 14.3 & $\begin{array}{c}0.6 \\
0.6 \\
19.9 \\
0.6\end{array}$ & $\begin{array}{l}0.6 \\
60.8\end{array}$ & $\begin{array}{l}0.8 \\
40.5\end{array}$ & 57.1 & 45.7 & 70.0 \\
\hline
\end{tabular}

fers are greater than $90 \%$ in several horizons of the upper Miocene, although some of their assemblages represent species redeposited from shallower environments.

\section{PALEODEPTH}

Except for infrequent redeposited assemblages found in the middle to late Miocene, benthic foraminifers at Sites 794, 795, and 797 are generally characterized by deep or bathyal faunas. The principal species recognized include Cibicidoides wuellerstorfi, $C$. bradyi,
Oridorsalis umbonatus, Eggerella bradyi, Uvigerina proboscidea, and species of Melonis and Gyroidina. These latter taxa are noted by Boltovskoy (1984) as typical deep-sea assemblages of the modern world ocean inhabiting water depths of 2500 to $4000 \mathrm{~m}$.

It is well known that agglutinated foraminifers comprise more than $90 \%$ of the total fauna at depths deeper than about $1000 \mathrm{~m}$ in the modern Sea of Japan. According to Ujiie and Ichikura (1973), the calcium carbonate compensation depth (CCD) of the modern Sea of Japan is estimated to be at a depth of about 1437 to $1596 \mathrm{~m}$. More recently, Matoba and Honma (1986) estimated the CCD to be at 
Table 2 (continued).

\begin{tabular}{|c|c|c|c|c|c|c|c|c|}
\hline $\begin{array}{l}\text { Hole 795B } \\
\text { Section } \\
\text { Interval }(\mathrm{cm})\end{array}$ & $\begin{array}{l}28 \mathrm{R}-2 \\
118-119\end{array}$ & $\begin{array}{l}28 R-4 \\
117-119\end{array}$ & $\begin{array}{l}29 \mathrm{R}-2 \\
116-120\end{array}$ & $\begin{array}{l}29 \mathrm{R}-3 \\
116-120\end{array}$ & $\begin{array}{l}30 \mathrm{R}-2 \\
110-112\end{array}$ & $\begin{array}{l}\text { 3IR-1 } \\
\text { I12-114 }\end{array}$ & $\begin{array}{l}32 \mathrm{R}-1 \\
106-107\end{array}$ & $\begin{array}{l}33 \mathrm{R}-1 \\
106-109\end{array}$ \\
\hline $\begin{array}{l}\text { Melonis nikobarense } \\
\text { Melonis pompilioides } \\
\text { Nodosaria sp. } \\
\text { Oolina sp. A } \\
\text { Oolina sp. B }\end{array}$ & & & & 0.8 & & & & \\
\hline $\begin{array}{l}\text { Oolina sp. } \\
\text { Oridorsalis umbonatus } \\
\text { Plectina nipponica } \\
\text { Proteonina compressa } \\
\text { Proteonina cf. compressa }\end{array}$ & 1.6 & 4.1 & $\begin{array}{c}0.6 \\
11.5\end{array}$ & 3.8 & & & & \\
\hline $\begin{array}{l}\text { Pullenia bulloides } \\
\text { Pullenia quinqueloba } \\
\text { Pullenia salisburyi } \\
\text { Pyrgo sp. } \\
\text { Pyrgo? sp. }\end{array}$ & 3.3 & 2.0 & $\begin{array}{l}0.6 \\
0.6\end{array}$ & & & & & \\
\hline $\begin{array}{l}\text { Quadrimorphina sp. } \\
\text { Quinqueloculina sp. } \\
\text { Reophax spp. } \\
\text { Reophax? sp. } \\
\text { Rhabdammina spp. }\end{array}$ & + & 2.0 & $\begin{array}{l}0.6 \\
0.6 \\
+\end{array}$ & + & + & + & + & + \\
\hline $\begin{array}{l}\text { Saccammina cf. sphaerica } \\
\text { Schizammina sp. } \\
\text { Sphaeroidina japonica } \\
\text { Sphaeroidina sp. } \\
\text { Spirosigmoilinella compressa }\end{array}$ & $\begin{array}{c}3.3 \\
+\end{array}$ & 2.0 & $\begin{array}{c}0.6 \\
+ \\
0.6\end{array}$ & 2.3 & & & 20.7 & 13.8 \\
\hline $\begin{array}{l}\text { Stilostomella sp. } \\
\text { Technitella sp. } \\
\text { Textularia sp. } \\
\text { Thalmannammina cf. parkerae } \\
\text { Thalmannammina? sp. }\end{array}$ & & & 1.9 & & & & & \\
\hline $\begin{array}{l}\text { Trochammina cf. globigeriniformis } \\
\text { Trochammina? sp. } \\
\text { Uvigerina proboscidea } \\
\text { Valvulinerina sp. }\end{array}$ & & & $\begin{array}{l}1.3 \\
3.8\end{array}$ & & & & & \\
\hline Miscellaneous taxa & 8.1 & 24.5 & 5.8 & 2.4 & 34.4 & 25.0 & 15.2 & 0.2 \\
\hline
\end{tabular}

$1850 \mathrm{~m}$ off Tsugaru Peninsula, Northeast Japan. These data suggest that the Miocene agglutinated faunas found at Sites 794, 795, and 797 represent water depths greater than the local CCD. However, the CCD in the Pacific and Indian oceans oscillated between approximately 3500 and $5000 \mathrm{~m}$ during the Miocene, becoming shallower in the early and middle Miocene (van Andel, 1975; Petersen and Backman, 1990). These latter depths are much deeper than the modern CCD in the Sea of Japan. Calcareous faunas are obviously indicative of depths shallower than the CCD. The occurrences of dominantly agglutinated faunas in Miocene sediments in the Sea of Japan suggest that the CCD in the marginal sea is much different from the open ocean Cenozoic CCD history. Thus, paleodepths based on CCD records from the open ocean are not reliable in this setting. Many local environmental factors may influence the CCD in the Sea of Japan; moreover, the difference between the Yamato and Japan basins may be a result of different rates of supply of calcium carbonate to deep water in these areas.

Aside from foraminiferal wall types (e.g., agglutinated versus calcareous tests), the following species and genera, although limited in number, permit paleodepth estimates. Ammodiscus macilentus occurs commonly at the three ODP sites and is morphologically similar to Recent $A$. gullmarensis reported by Matoba and Honma (1986) as abundant at $1850 \mathrm{~m}$ in the modern Sea of Japan. Thalmannammina $\mathrm{cf}$. parkerae is similar to Recent $T$. parkerae, a species which is very abundant at depths greater than $1000 \mathrm{~m}$. Spirosigmoilinella compressa is similar to Silicosigmoilina abyssalica, which is common in modern deep regions of the Sea of Japan (Inoue, 1980; Ujiie et al., 1983). Matoba and Honma (1986), for example, report that $S$. abyssalica forms peak abundances at depths of 1850 to $2300 \mathrm{~m}$ in the modern Sea of Japan. Both Cibicidoides wuellerstorfi and $C$. bradyi are commonly reported from lower bathyal depths in the open ocean, although their occurrences are not common in the modern Sea of Japan. Cibicidoides wuellerstorfi is noted as having an upper depth limit of about 1800-1900 m on the continental margin of the northeastern United States and being very abundant deeper than $3000 \mathrm{~m}$ in the Gulf of California (van Morkhoven et al., 1986). Cibicidoides bradyi occurs at abyssal depths (van Morkhoven et al., 1986). In addition, Thompson (1980) reported the following dominant species from the Japan Trench area: Calcareous taxa Chilostomella oolina, Nonionellina labradorica, and Melonis pompilioides from depths of $1800-3300 \mathrm{~m}$ in depth and agglutinated species such as Eggerella bradyi, Saccammina sphaerica, and Martinottiella communis from 3300 to $6000 \mathrm{~m}$.

On the basis of these data, the oldest sediments (lithological Unit V) at Sites 794 and 795 were likely deposited at lower bathyal to upper abyssal depths (1000-3000 m) based on van Morkhoven et al. (1986)'s depth divisions. At Site 797, the foraminiferal occurrences 

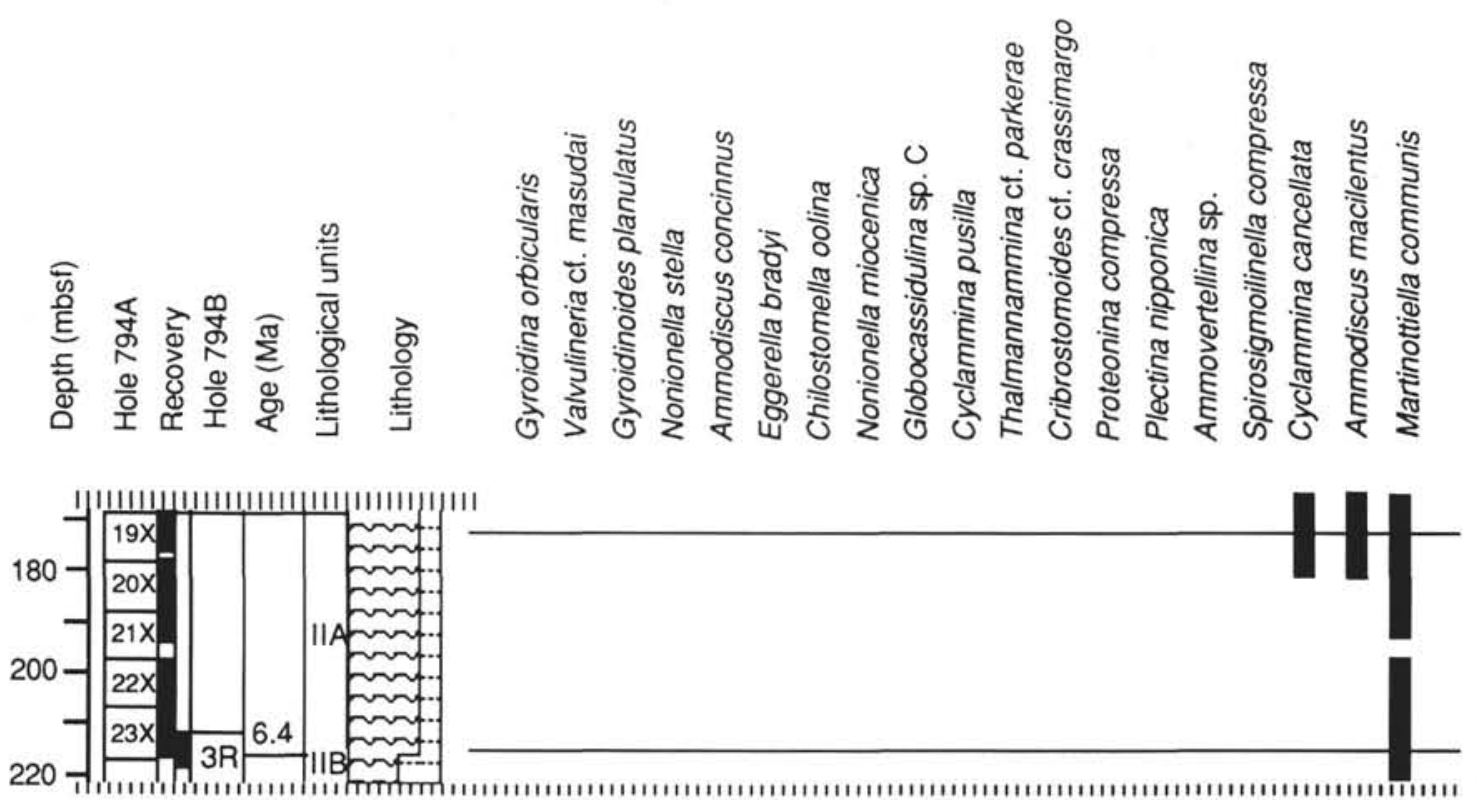

Assemblage Zones

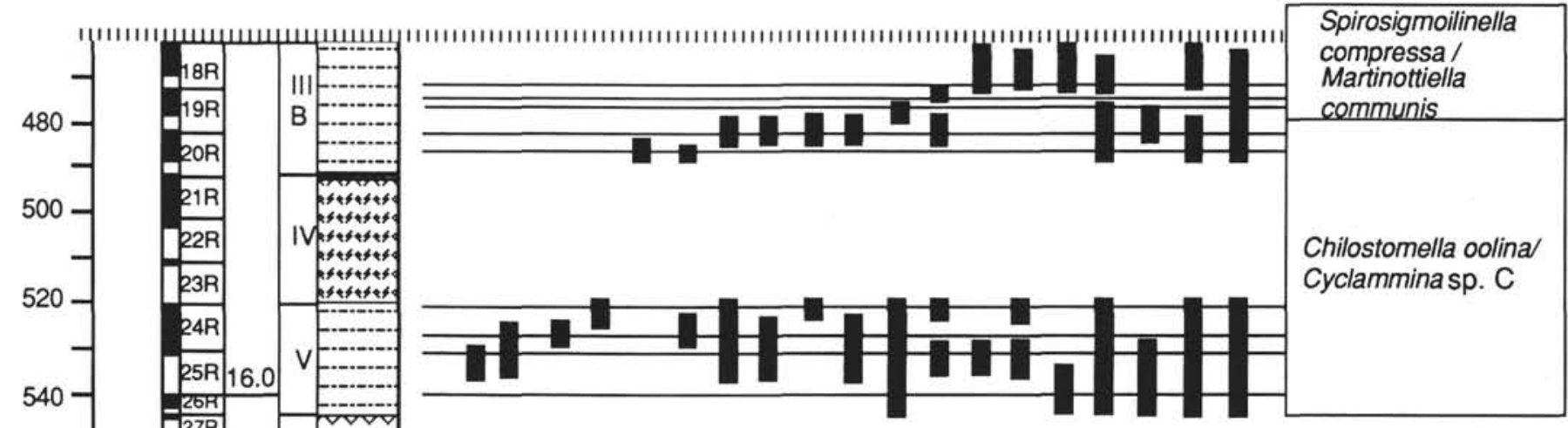

are much reduced below lithological Units V to VI, but the first appearances of $T$. cf. parkerae at 22R-5, 146-150 cm (692.5 mbsf), and A. macilentus at 18R-1, 130-134 cm (647.8 mbsf), also indicate the lower bathyal to upper abyssal depths. Bathysiphon sp., which occurs from Sample 127-797C-41R-CC (30-34 cm), does not suggest paleodepth but rather is interpreted to represent an oxygen-deficient marine bottom environment formed in the early Miocene.

\section{THE FORAM SHARP LINE}

The Foram Sharp Line (FSL) was introduced by Tai (1963) to define a horizon showing a distinct faunal change in the middle Miocene sequences of the Sea of Japan borderland region. The term "Foram" is abbreviated from the adjective "foraminiferal." This horizon or FSL was originally defined as the abrupt change from diversified calcareous and agglutinated foraminifers to a low-diversity fauna consisting only of agglutinated foraminifers or in some cases, a barren interval (Fig. 18). According to Tai $(1963,1985,1988)$ and Serova and Tai (1977), a similar faunal change is present not only in Japan but also in Korea (Pohan Basin) as well as in Sakhalin and Kamchatka sequences facing the Okhotsku Sea. This characteristic faunal change or FSL is most typically shown in the middle Miocene sequences of Southwest Honshu. Faunas stratigraphically below the FSL consist of tropical to subtropical shallow water forms of Miogypsina and Operculina and forms such as Uvigerina, Stilostomella, Nonion, Trifarina, Buccella, Gaudryina, Bolivina, Bulimina, Hanzawaia, and Cibicides. In contrast, the faunas stratigraphically above the FSL consist mainly of Bathysiphon, Haplophragmoides, Cyclammina, Gaudryina, Martinottiella, Sigmoilina, and Trochammina (Tai, 1985).

Tai (1985) stated that all these areas do not consistently show the same specific changes in faunal composition across the FSL. However, with respect to the change of faunal diversity they always exhibit a drastic change from higher to lower diversities across the FSL. Following Tai's (1963) definition, the FSL is recognizable at $14.4 \mathrm{Ma}$ at Site 794, 11.2 Ma at Site 795, and 14.3 Ma at Site 797 (Fig. 19). Onshore, the ages of the FSL have been estimated at about 14-15 Ma from Northeast and Southwest Honshu (Maiya and Inoue, 1981; Maiya, 1988; Nomura, in press). Thus, the position of the FSL at ODP sites in the Yamato Basin correlate well with the onshore occurrences. Alternatively, the FSL in the Japan Basin occurs about 3 m.y. later, and a time lag of the FSL is assumed from southern to northern sites. However, the FSL (11.2 Ma) at Site 795 appears in cooler temperatures of water mass in the northern Sea of Japan, because disappearance of the warm-water planktonic fauna from the onshore sequences occurred at the N11/12 boundary (about $12.8 \mathrm{Ma}$ ) (Maiya and Inoue, 1981; Fig. 20). Thus, the FSL at Site 795 occurred in water masses different from those of Sites 794 and 797. This indicates that the 


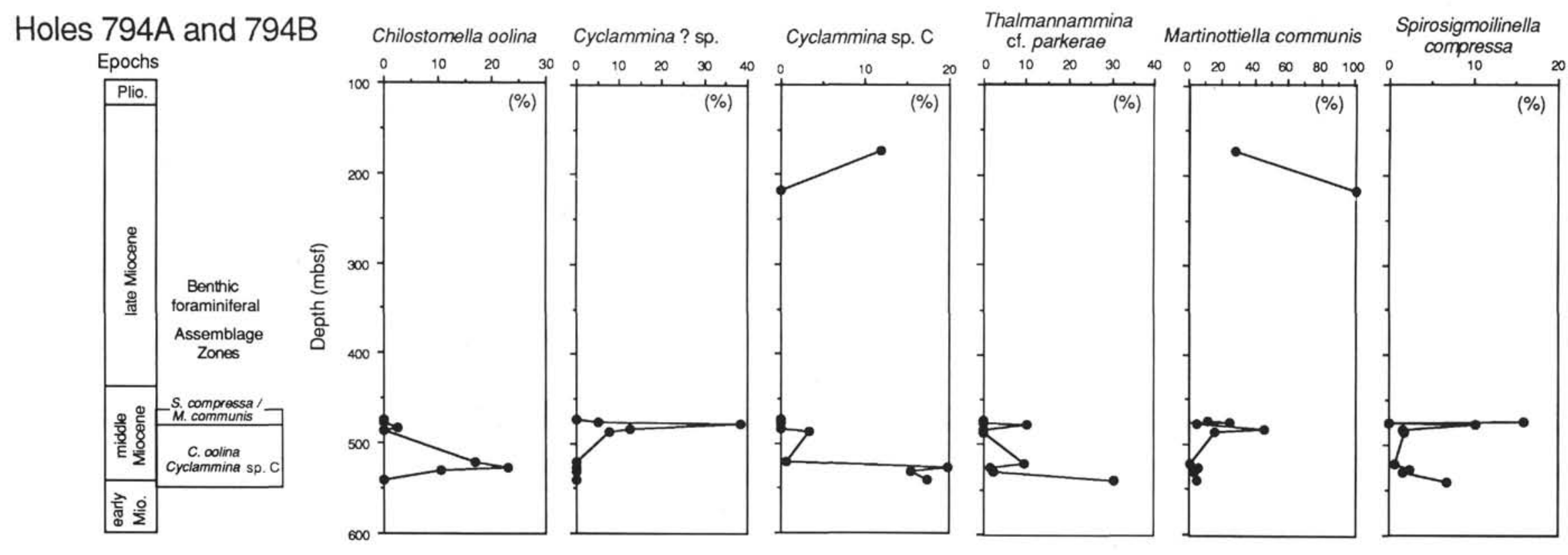

Figure 6. Frequency distribution of dominant benthic foraminifers from Site 794 in terms of percent of total benthic foraminifer population. 
Table 3. Benthic foraminiferal distribution (\%) at Site 797.

\begin{tabular}{|c|c|c|c|c|c|c|c|c|c|c|c|c|c|}
\hline $\begin{array}{l}\text { Holes } 797 \mathrm{~B} \text { and } 797 \mathrm{C} \\
\text { Section } \\
\text { Interval }(\mathrm{cm})\end{array}$ & $\begin{array}{l}797 \mathrm{~B}- \\
27 \mathrm{X}-3 \\
52-57\end{array}$ & $\begin{array}{l}27 X-4 \\
52-57\end{array}$ & $\begin{array}{l}28 X-1 \\
51-56\end{array}$ & $\begin{array}{l}30 \times-5 \\
52-57\end{array}$ & $\begin{array}{l}31 X-3 \\
50-54\end{array}$ & $\begin{array}{l}32 X-6 \\
51-55\end{array}$ & $\begin{array}{l}33 X-4 \\
52-54\end{array}$ & $\begin{array}{l}34 X-1 \\
52-56\end{array}$ & $\begin{array}{l}34 X-3 \\
50-54\end{array}$ & $\begin{array}{l}35 X-1 \\
51-55\end{array}$ & $\begin{array}{l}35 \times-4 \\
50-54\end{array}$ & $\begin{array}{l}35 X-6 \\
50-54\end{array}$ & $\begin{array}{l}37 X-1 \\
52-56\end{array}$ \\
\hline $\begin{array}{l}\text { Ammodiscus macilentus } \\
\text { Ammodiscus sp. A } \\
\text { Ammodiscus spp. } \\
\text { Ammodiscus tenuis } \\
\text { Ammosphaeroidina sp. }\end{array}$ & & & & & & & & & 1.69 & & & & \\
\hline $\begin{array}{l}\text { Ammovertellina } \\
\text { Astrononion sp. } \\
\text { Bathysiphon spp. } \\
\text { Brizalina sp. } \\
\text { Buccella cf. kuromatsunaiensis }\end{array}$ & + & & & + & 3.11 & & & & & & + & & + \\
\hline $\begin{array}{l}\text { Bulimina } \text { cf. rostrata } \\
\text { Bulimina } \text { sp. } \\
\text { Bulimina striata } \\
\text { Bulimina } \text { cf. striata } \\
\text { Chilostomella oolina }\end{array}$ & & & & & & & & & 40.68 & & 0.78 & & \\
\hline $\begin{array}{l}\text { Cibicides } \mathrm{cf} \text {. refulgens } \\
\text { Cibicides sp. } \\
\text { Cibicidoides? sp. } \\
\text { Cibicidoides bradyi } \\
\text { Cibicidoides sp. }\end{array}$ & & & & & $\begin{array}{l}35.11 \\
0.44\end{array}$ & & & & 6.78 & & 0.78 & & \\
\hline $\begin{array}{l}\text { Cibicidoides sp. A } \\
\text { Cibicidoides sp. B } \\
\text { Cibicidoides wuellerstorfi } \\
\text { Cribrostomoides? sp. } \\
\text { Cribrostomoides } \mathrm{cf} \text {. crassimargo }\end{array}$ & 16.67 & & & & & & 8.00 & & 1.69 & & 2.33 & & \\
\hline $\begin{array}{l}\text { Cyclammina? sp. } \\
\text { Cyclammina cancellata } \\
\text { Cyclammina orbicularis } \\
\text { Cyclammina pusilla } \\
\text { Cyclammina sp. A }\end{array}$ & & & & 14.29 & & & & & & & & & \\
\hline $\begin{array}{l}\text { Dentalina insecta } \\
\text { Dentalina } \mathrm{sp} . \\
\text { Dentalina? sp. } \\
\text { Eggerella } \mathrm{sp} . \mathrm{A} \\
\text { Elphidium } \mathrm{cf} \text {. jenseni }\end{array}$ & & & & & 0.44 & & & & & & & & \\
\hline $\begin{array}{l}\text { Elphidium spp. } \\
\text { Elphidium subarcticum } \\
\text { Evolvocassidulina kuwanoi } \\
\text { Fissurina marginata } \\
\text { Fissurina orbignyana }\end{array}$ & & & & & $\begin{array}{c}0.44 \\
10.22 \\
0.44\end{array}$ & & & & & & & & \\
\hline $\begin{array}{l}\text { Fissurina sp. A } \\
\text { Fursenkoina sp. A } \\
\text { Gavelinopsis sp. } \\
\text { Glabratella suboperculosis } \\
\text { Globobulimina perversa }\end{array}$ & & & & & $\begin{array}{l}0.44 \\
1.33 \\
1.33\end{array}$ & & & & & & 0.78 & & \\
\hline $\begin{array}{l}\text { Globobulimina cf. perversa } \\
\text { Globobulimina pupoides } \\
\text { Globobulimina spp. } \\
\text { Globocassidulina globosa (s.1.) } \\
\text { Globocassidulina sp. A }\end{array}$ & & & & 28.57 & 5.33 & $\begin{array}{l}50.00 \\
50.00\end{array}$ & 28.00 & & 1.69 & 40.00 & $\begin{array}{l}7.75 \\
0.78 \\
1.55\end{array}$ & 20.00 & 50.00 \\
\hline $\begin{array}{l}\text { Glomospira sp. } \\
\text { Gyroidina orbicularis } \\
\text { Gyroidinoides planulatus } \\
\text { Gyroidinoides cf. planulatus } \\
\text { Hippocrepinella? }\end{array}$ & & & & 28.57 & 0.44 & & & & 10.17 & & $\begin{array}{c}3.10 \\
14.73\end{array}$ & & \\
\hline $\begin{array}{l}\text { Hormosina spp. } \\
\text { Islandiella cf. compressa } \\
\text { Islandiella helenae } \\
\text { Islandiella } \text { sp. A } \\
\text { Lagena } \mathrm{cf} \text { apiopleura }\end{array}$ & & & & & $\begin{array}{c}6.67 \\
20.89 \\
0.44\end{array}$ & & & & & & & & \\
\hline $\begin{array}{l}\text { Lenticulina spp. } \\
\text { Marginulina sp. } \\
\text { Martinottiella communis } \\
\text { Martinottiella } \text { cf. communis } \\
\text { Melonis nikobarense }\end{array}$ & 66.67 & 100.00 & 92.86 & & & & 12.00 & 50.00 & 10.17 & & 0.78 & 20.00 & \\
\hline
\end{tabular}


Table 3 (continued).

\begin{tabular}{|c|c|c|c|c|c|c|c|c|c|c|c|c|c|}
\hline $\begin{array}{l}\text { Holes 797B and 797C } \\
\text { Section } \\
\text { Interval }(\mathrm{cm})\end{array}$ & $\begin{array}{l}797 \mathrm{~B}- \\
27 \mathrm{X}-3 \\
52-57\end{array}$ & $\begin{array}{l}27 X-4 \\
52-57\end{array}$ & $\begin{array}{l}28 X-1 \\
51-56\end{array}$ & $\begin{array}{l}30 X-5 \\
52-57\end{array}$ & $\begin{array}{l}31 X-3 \\
50-54\end{array}$ & $\begin{array}{l}32 X-6 \\
51-55\end{array}$ & $\begin{array}{l}33 X-4 \\
52-54\end{array}$ & $\begin{array}{l}34 \mathrm{X}-1 \\
52-56\end{array}$ & $\begin{array}{l}34 X-3 \\
50-54\end{array}$ & $\begin{array}{l}35 X-1 \\
51-55\end{array}$ & $\begin{array}{l}35 X-4 \\
50-54\end{array}$ & $\begin{array}{l}35 \mathrm{X}-6 \\
50-54\end{array}$ & $\begin{array}{l}37 \mathrm{X}-1 \\
52-56\end{array}$ \\
\hline $\begin{array}{l}\text { Melonis pompilioides } \\
\text { Miliolinella sp. } \\
\text { Nodosaria? sp. } \\
\text { Nonionellina labradorica } \\
\text { Nonionella }\end{array}$ & & & & & & & & & 5.08 & & & & \\
\hline $\begin{array}{l}\text { Nonionella cf. miocenica } \\
\text { Nonionella stella } \\
\text { Oolina globosa } \\
\text { Oolina hexagona } \\
\text { Oolina? sp. }\end{array}$ & & & 7.14 & & & & & & & & 2.33 & & \\
\hline $\begin{array}{l}\text { Oridorsalis umbonatus } \\
\text { Oridorsalis spp. } \\
\text { Parafissulina } \mathrm{sp} . \\
\text { Planodiscorbis sp. } \\
\text { Plectina nipponica }\end{array}$ & & & & & & & 4.00 & & & & 51.16 & & \\
\hline $\begin{array}{l}\text { Plectina? sp. } \\
\text { Proteonina sp. } \\
\text { Proteonina? sp. } \\
\text { Pullenia bulloides } \\
\text { Pullenia quinqueloba }\end{array}$ & & & & & & & 4.00 & & & & 1.55 & & \\
\hline $\begin{array}{l}\text { Pullenia salisburyi } \\
\text { Pullenia subcarinata } \\
\text { Pullenia cf. subcarinata } \\
\text { Pullenia sp. } \\
\text { Pullenia? sp. }\end{array}$ & & & & 28.57 & & & & & $\begin{array}{l}1.69 \\
1.69\end{array}$ & 10.00 & $\begin{array}{l}1.55 \\
1.55\end{array}$ & & \\
\hline $\begin{array}{l}\text { Pyrgo cf. vespertilio } \\
\text { Pyrgo murrhina } \\
\text { Pyrgo spp. } \\
\text { Quadrimorphina sp. } \\
\text { Quinqueloculina cf. seminula }\end{array}$ & & & & & & & 4.00 & & & 10.00 & $\begin{array}{l}0.78 \\
3.88\end{array}$ & & \\
\hline $\begin{array}{l}\text { Quinqueloculina vulgaris } \\
\text { Quinqueloculina sp. A } \\
\text { Quinqueloculina sp. B } \\
\text { Quinqueloculina spp. } \\
\text { Quinqueloculina? sp. }\end{array}$ & & & & & & & & & & & 0.78 & & \\
\hline $\begin{array}{l}\text { Recurvoides? sp. } \\
\text { Reophax excentricus } \\
\text { Reophax spp. } \\
\text { Reophax? sp. } \\
\text { Rhabdammina spp. }\end{array}$ & & & & & & & & & & & & + & \\
\hline $\begin{array}{l}\text { Saccammina sp. } \\
\text { Saracenaria sp. } \\
\text { Schizammina sp. } \\
\text { Sphaeroidina cf. compacta } \\
\text { Sphaeroidina japonica }\end{array}$ & & & & & 0.44 & & & & + & & & & \\
\hline $\begin{array}{l}\text { Sphaeroidina cf. japonica } \\
\text { Spirosigmoilinella compressa } \\
\text { Spirosigmoilinella? sp. } \\
\text { Thalmannammina cf. parkerae } \\
\text { Tosaia hanzawai }\end{array}$ & & & & & & & & 50.00 & & & & & \\
\hline $\begin{array}{l}\text { Trifarina sp. } \\
\text { Triloculina sp. } \\
\text { Trochammina } \text { sp. } \\
\text { Uvigerina cf. modeloensis } \\
\text { Uvigerina cf. segundoensis }\end{array}$ & & & & & 11.56 & & & & & & 0.78 & & \\
\hline $\begin{array}{l}\text { Uvigerina proboscidea } \\
\text { Uvigerina cf. proboscidea } \\
\text { Uvigerina sp. } \\
\text { Valvulineria cf. sadonica } \\
\text { Valvulineria masudai }\end{array}$ & & & & & 0.44 & & & & & 20.00 & 1.55 & & \\
\hline Valvulineria spp. & & & & & & & & & 1.69 & & & & \\
\hline Miscellaneous taxa & 16.67 & & & & 0.44 & & 40.00 & & 16.95 & 20.00 & 0.78 & 60.00 & 50.00 \\
\hline
\end{tabular}


Table 3 (continued).

\begin{tabular}{|c|c|c|c|c|c|c|c|c|c|c|c|c|c|}
\hline $\begin{array}{l}\text { Holes 797B and 797C } \\
\text { Section } \\
\text { Interval }(\mathrm{cm})\end{array}$ & $\begin{array}{l}37 \mathrm{X}-2 \\
48-52\end{array}$ & $\begin{array}{l}37 X-3 \\
51-55\end{array}$ & $\begin{array}{l}37 X-4 \\
51-55\end{array}$ & $\begin{array}{c}38 \mathrm{X}-1 \\
50-54\end{array}$ & $\begin{array}{l}40 \mathrm{X}-2 \\
35-39\end{array}$ & $\begin{array}{l}41 X-1 \\
34-38\end{array}$ & $\begin{array}{l}43 X-1 \\
35-39\end{array}$ & $\begin{array}{l}44 \mathrm{X}-1 \\
36-40\end{array}$ & $\begin{array}{l}46 \mathrm{X}-1 \\
28-32\end{array}$ & $\begin{array}{l}47 X-1 \\
45-49\end{array}$ & $\begin{array}{l}47 X-3 \\
52-56\end{array}$ & $\begin{array}{l}48 X-1 \\
68-72\end{array}$ & $\begin{array}{l}48 X-2 \\
53-57\end{array}$ \\
\hline $\begin{array}{l}\text { Ammodiscus macilentus } \\
\text { Ammodiscus sp. A } \\
\text { Ammodiscus spp. } \\
\text { Ammodiscus tenuis } \\
\text { Ammosphaeroidina } \text { sp. }\end{array}$ & & & & & & & & & & 1.26 & & $\begin{array}{l}0.49 \\
1.46\end{array}$ & $\begin{array}{l}0.38 \\
0.38\end{array}$ \\
\hline $\begin{array}{l}\text { Ammovertellina } \\
\text { Astrononion sp. } \\
\text { Bathysiphon spp. } \\
\text { Brizalina sp. } \\
\text { Buccella } \text { cf. kuromatsunaiensis }\end{array}$ & + & & & + & + & & & & + & 0.63 & & $\begin{array}{l}1.46 \\
+\end{array}$ & $\begin{array}{c}0.38 \\
+\end{array}$ \\
\hline $\begin{array}{l}\text { Bulimina } \text { cf. rostrata } \\
\text { Bulimina } \mathrm{sp.} \\
\text { Bulimina striata } \\
\text { Butimina cf. striata } \\
\text { Chilostomella oolina }\end{array}$ & & & & 6.25 & & & & & & 0.63 & & 0.49 & 1.51 \\
\hline $\begin{array}{l}\text { Cibicides cf. refulgens } \\
\text { Cibicides sp. } \\
\text { Cibicidoides? sp. } \\
\text { Cibicidoides bradyi } \\
\text { Cibicidoides sp. }\end{array}$ & & & 7.69 & & 0.62 & & & & & & & & 4.91 \\
\hline $\begin{array}{l}\text { Cibicidoides } \mathrm{sp} . \mathrm{A} \\
\text { Cibicidoides } \mathrm{sp} . \mathrm{B} \\
\text { Cibicidoides wuellerstorfi } \\
\text { Cribrostomoides? sp. } \\
\text { Cribrostomoides } \mathrm{cf} \text {. crassimargo }\end{array}$ & & 25.00 & & & 14.29 & & & & & $\begin{array}{l}27.04 \\
43.40\end{array}$ & $\begin{array}{l}18.54 \\
48.31\end{array}$ & $\begin{array}{l}8.25 \\
67.48\end{array}$ & $\begin{array}{r}2.26 \\
55.85\end{array}$ \\
\hline $\begin{array}{l}\text { Cyclammina? sp. } \\
\text { Cyclammina cancellata } \\
\text { Cyclammina orbicularis } \\
\text { Cyclammina pusilla } \\
\text { Cyclammina sp. A }\end{array}$ & & & & & & & 33.33 & & & & & & 9.06 \\
\hline $\begin{array}{l}\text { Dentalina insecta } \\
\text { Dentalina sp. } \\
\text { Dentalina? sp. } \\
\text { Eggerella sp. A } \\
\text { Elphidium cf. jenseni }\end{array}$ & & & & & & & & & & & & 0.49 & \\
\hline $\begin{array}{l}\text { Elphidium spp. } \\
\text { Elphidium subarcticum } \\
\text { Evolvocassidulina kuwanoi } \\
\text { Fissurina marginata } \\
\text { Fissurina orbignyana }\end{array}$ & & & & & & & & & & & & & $\begin{array}{l}0.38 \\
1.89\end{array}$ \\
\hline $\begin{array}{l}\text { Fissurina } \mathrm{sp} . \mathrm{A} \\
\text { Fursenkoina } \mathrm{sp} . \mathrm{A} \\
\text { Gavelinopsis } \mathrm{sp} . \\
\text { Glabratella suboperculosis } \\
\text { Globobulimina perversa }\end{array}$ & & & & & 0.62 & & & & & & & 0.97 & 0.38 \\
\hline $\begin{array}{l}\text { Globobulimina cf. perversa } \\
\text { Globobulimina pupoides } \\
\text { Globobulimina spp. } \\
\text { Globocassidulina globosa (s.1.) } \\
\text { Globocassidulina sp. A }\end{array}$ & & & 7.69 & & & & & & & 6.92 & $\begin{array}{l}1.69 \\
8.43\end{array}$ & 5.83 & $\begin{array}{l}0.38 \\
1.13 \\
4.53\end{array}$ \\
\hline $\begin{array}{l}\text { Glomospira sp. } \\
\text { Gyroidina orbicularis } \\
\text { Gyroidinoides planulatus } \\
\text { Gyroidinoides cf. planulatus } \\
\text { Hippocrepinella? }\end{array}$ & & $\begin{array}{l}50.00 \\
25.00\end{array}$ & & & $\begin{array}{l}8.07 \\
4.97\end{array}$ & & & & & $\begin{array}{l}0.63 \\
1.26 \\
0.63\end{array}$ & $\begin{array}{l}1.12 \\
1.69\end{array}$ & $\begin{array}{l}0.49 \\
4.37 \\
0.49\end{array}$ & $\begin{array}{l}1.51 \\
1.89\end{array}$ \\
\hline $\begin{array}{l}\text { Hormosina spp. } \\
\text { Islandiella cf. compressa } \\
\text { Islandiella helenae } \\
\text { Islandiella sp. A } \\
\text { Lagena cf. apiopleura }\end{array}$ & & & & & & & & & & & & & \\
\hline $\begin{array}{l}\text { Lenticulina spp. } \\
\text { Marginulina sp. } \\
\text { Martinottiella communis } \\
\text { Martinottiella cf. communis } \\
\text { Melonis nikobarense }\end{array}$ & 60.00 & & 23.08 & 56.25 & $\begin{array}{l}0.62 \\
8.07 \\
0.62\end{array}$ & 4.35 & & 28.57 & & $\begin{array}{l}0.63 \\
2.52\end{array}$ & 3.93 & $\begin{array}{l}0.97 \\
2.43\end{array}$ & 0.38 \\
\hline
\end{tabular}


Table 3 (continued).

\begin{tabular}{|c|c|c|c|c|c|c|c|c|c|c|c|c|c|}
\hline $\begin{array}{l}\text { Holes 797B and 797C } \\
\text { Section } \\
\text { Interval }(\mathrm{cm})\end{array}$ & $\begin{array}{l}37 \mathrm{X}-2 \\
48-52\end{array}$ & $\begin{array}{l}37 \mathrm{X}-3 \\
51-55\end{array}$ & $\begin{array}{l}37 X-4 \\
51-55\end{array}$ & $\begin{array}{l}38 \mathrm{X}-1 \\
50-54\end{array}$ & $\begin{array}{l}40 X-2 \\
35-39\end{array}$ & $\begin{array}{l}41 X-1 \\
34-38\end{array}$ & $\begin{array}{l}43 \mathrm{X}-1 \\
35-39\end{array}$ & $\begin{array}{l}44 X-1 \\
36-40\end{array}$ & $\begin{array}{l}46 \mathrm{X}-1 \\
28-32\end{array}$ & $\begin{array}{l}47 X-1 \\
45-49\end{array}$ & $\begin{array}{l}47 \mathrm{X}-3 \\
52-56\end{array}$ & $\begin{array}{l}48 \mathrm{X}-1 \\
68-72\end{array}$ & $\begin{array}{l}48 \mathrm{X}-2 \\
53-57\end{array}$ \\
\hline $\begin{array}{l}\text { Melonis pompilioides } \\
\text { Miliolinella sp. } \\
\text { Nodosaria? sp. } \\
\text { Nonionellina labradorica } \\
\text { Nonionella }\end{array}$ & & & 15.38 & & 5.59 & & & & & 0.63 & & & \\
\hline $\begin{array}{l}\text { Nonionella cf. miocenica } \\
\text { Nonionella stella } \\
\text { Oolina globosa } \\
\text { Oolina hexagona } \\
\text { Oolina? sp. }\end{array}$ & & & & & 0.62 & & & & & & & & 0.38 \\
\hline $\begin{array}{l}\text { Oridorsalis umbonatus } \\
\text { Oridorsalis spp. } \\
\text { Parafissulina } \mathrm{sp} . \\
\text { Planodiscorbis sp. } \\
\text { Plectina nipponica }\end{array}$ & & & & & 6.83 & & & & & 0.63 & 2.81 & 0.49 & 4.91 \\
\hline $\begin{array}{l}\text { Plectina? sp. } \\
\text { Proteonina sp. } \\
\text { Proteonina? sp. } \\
\text { Pullenia bulloides } \\
\text { Pullenia quinqueloba }\end{array}$ & 10.00 & & & & $\begin{array}{l}1.24 \\
0.62\end{array}$ & & & & & 3.77 & 5.06 & 0.97 & 2.64 \\
\hline $\begin{array}{l}\text { Pullenia salisburyi } \\
\text { Pullenia subcarinata } \\
\text { Pullenia cf. subcarinata } \\
\text { Pullenia sp. } \\
\text { Pullenia? sp. }\end{array}$ & & & & & 0.62 & & & & & 1.89 & 7.30 & 0.49 & 2.26 \\
\hline $\begin{array}{l}\text { Pyrgo cf. vespertilio } \\
\text { Pyrgo murrhina } \\
\text { Pyrgo spp. } \\
\text { Quadrimorphina sp. } \\
\text { Quinqueloculina cf. seminula }\end{array}$ & & & & & & & & & & & & & \\
\hline $\begin{array}{l}\text { Quinqueloculina vulgaris } \\
\text { Quinqueloculina sp. A } \\
\text { Quinqueloculina sp. B } \\
\text { Quinqueloculina spp. } \\
\text { Quinqueloculina? sp. }\end{array}$ & & & & & 0.62 & & & & & & & & $\begin{array}{l}1.51 \\
0.38\end{array}$ \\
\hline $\begin{array}{l}\text { Recurvoides? sp. } \\
\text { Reophax excentricus } \\
\text { Reophax spp. } \\
\text { Reophax? sp. } \\
\text { Rhabdammina spp. }\end{array}$ & & & & & & & & & & & & & \\
\hline $\begin{array}{l}\text { Saccammina sp. } \\
\text { Saracenaria sp. } \\
\text { Schizammina sp. } \\
\text { Sphaeroidina cf. compacta } \\
\text { Sphaeroidina japonica }\end{array}$ & & & & 18.75 & & & & & & & & & \\
\hline $\begin{array}{l}\text { Sphaeroidina cf. japonica } \\
\text { Spirosigmoilinella compressa } \\
\text { Spirosigmoilinella? sp. } \\
\text { Thalmannammina cf. parkerae } \\
\text { Tosaia hanzawai }\end{array}$ & 10.00 & & & & 0.62 & & & & & $\begin{array}{l}1.26 \\
2.52\end{array}$ & & $\begin{array}{l}0.49 \\
0.49\end{array}$ & \\
\hline $\begin{array}{l}\text { Trifarina sp. } \\
\text { Triloculina sp. } \\
\text { Trochammina } \text { sp. } \\
\text { Uvigerina cf. modeloensis } \\
\text { Uvigerina cf. segundoensis }\end{array}$ & & & & & & & & & & & & & \\
\hline $\begin{array}{l}\text { Uvigerina proboscidea } \\
\text { Uvigerina cf. proboscidea } \\
\text { Uvigerina sp. } \\
\text { Valvulineria cf. sadonica } \\
\text { Valvulineria masudai }\end{array}$ & & & & & 42.24 & & & & & 1.89 & 0.56 & & \\
\hline Valvulineria spp. & & & 7.69 & & & & & & & & & & 0.38 \\
\hline Miscellaneous taxa & 20,00 & & 38.46 & 18.75 & 3.11 & 95.65 & 66.67 & 71.43 & & 1.89 & 0.56 & 1.46 & \\
\hline
\end{tabular}




\section{R. NOMURA}

Table 3 (continued).

\begin{tabular}{|c|c|c|c|c|c|c|c|c|c|c|c|c|c|}
\hline $\begin{array}{l}\text { Holes } 797 \mathrm{~B} \text { and } 797 \mathrm{C} \\
\text { Section } \\
\text { Interval }(\mathrm{cm})\end{array}$ & $\begin{array}{l}48 X-4 \\
56-60\end{array}$ & $\begin{array}{l}49 X-2 \\
50-54\end{array}$ & $\begin{array}{l}49 X-4 \\
52-56\end{array}$ & $\begin{array}{l}51 X-1 \\
51-53\end{array}$ & $\begin{array}{l}51 X-3 \\
51-53\end{array}$ & $\begin{array}{l}51 X-5 \\
51-53\end{array}$ & $\begin{array}{l}52 X-1 \\
45-49\end{array}$ & $\begin{array}{l}52 X-3 \\
50-54\end{array}$ & $\begin{array}{l}52 X-6 \\
50-54\end{array}$ & $\begin{array}{l}797 \mathrm{C}- \\
2 \mathrm{R}-2 \\
28-32\end{array}$ & $\begin{array}{l}5 R-2 \\
76-80\end{array}$ & $\begin{array}{l}5 R-4 \\
39-43\end{array}$ & $\begin{array}{l}6 \mathrm{R}-1 \\
56-60\end{array}$ \\
\hline $\begin{array}{l}\text { Ammodiscus macilentus } \\
\text { Ammodiscus sp. A } \\
\text { Ammodiscus spp. } \\
\text { Ammodiscus tenuis } \\
\text { Ammosphaeroidina sp. }\end{array}$ & 10.53 & 3.88 & & 2.88 & 1.12 & $\begin{array}{l}0.47 \\
1.42\end{array}$ & & & 3.57 & & $\begin{array}{l}7.95 \\
3.41\end{array}$ & $\begin{array}{l}1.22 \\
6.10\end{array}$ & $\begin{array}{l}1.94 \\
3.23\end{array}$ \\
\hline $\begin{array}{l}\text { Ammovertellina } \\
\text { Astrononion sp. } \\
\text { Bathysiphon } \mathrm{spp} \text {. } \\
\text { Brizalina } \mathrm{sp} \text {. } \\
\text { Buccella } \text { cf. kuromatsunaiensis }\end{array}$ & + & $\begin{array}{l}0.97 \\
+\end{array}$ & & & & + & $\stackrel{+}{+}$ & 0.34 & + & 3.19 & $\begin{array}{r}2.27 \\
+\end{array}$ & $\begin{array}{l}6.10 \\
+\end{array}$ & 0.65 \\
\hline $\begin{array}{l}\text { Bulimina } \text { cf. rostrata } \\
\text { Bulimina sp. } \\
\text { Bulimina striata } \\
\text { Bulimina cf. striata } \\
\text { Chilostomella oolina }\end{array}$ & & & & & & 0.95 & 7.14 & $\begin{array}{l}0.68 \\
4.10 \\
8.19\end{array}$ & 2.38 & 0.32 & & 1.22 & \\
\hline $\begin{array}{l}\text { Cibicides } \mathrm{cf} \text {. refulgens } \\
\text { Cibicides } \mathrm{sp} \text {. } \\
\text { Cibicidoides? } \mathrm{sp} . \\
\text { Cibicidoides bradyi } \\
\text { Cibicidoides sp. }\end{array}$ & & & & & 3.35 & $\begin{array}{l}0.47 \\
1.42\end{array}$ & & & 1.19 & & & & \\
\hline $\begin{array}{l}\text { Cibicidoides sp. A } \\
\text { Cibicidoides sp. B } \\
\text { Cibicidoides wuellerstorfi } \\
\text { Cribrostomoides? sp. } \\
\text { Cribrostomoides cf. crassimargo }\end{array}$ & 15.79 & $\begin{array}{l}18.45 \\
23.30\end{array}$ & 42.86 & $\begin{array}{l}20.86 \\
2.16\end{array}$ & $\begin{array}{l}15.64 \\
1.12 \\
0.56\end{array}$ & $\begin{array}{l}6.64 \\
0.95 \\
3.32\end{array}$ & $\begin{array}{l}7.14 \\
1.79\end{array}$ & 0.34 & $\begin{array}{l}2.38 \\
4.76\end{array}$ & 2.56 & & 1.22 & 0.65 \\
\hline $\begin{array}{l}\text { Cyclammina? sp. } \\
\text { Cyclammina cancellata } \\
\text { Cyclammina orbicularis } \\
\text { Cyclammina pusilla } \\
\text { Cyclammina sp. } \mathrm{A}\end{array}$ & & 1.94 & & $\begin{array}{l}0.72 \\
2.88\end{array}$ & $\begin{array}{l}6.70 \\
0.56\end{array}$ & $\begin{array}{l}3.79 \\
0.47\end{array}$ & 0.89 & & $\begin{array}{c}15.48 \\
2.38\end{array}$ & $\begin{array}{l}2.24 \\
25.24\end{array}$ & $\begin{array}{l}13.07 \\
31.82\end{array}$ & $\begin{array}{r}4.88 \\
59.76\end{array}$ & $\begin{array}{l}10.32 \\
3.87 \\
\\
42.58\end{array}$ \\
\hline $\begin{array}{l}\text { Dentalina insecta } \\
\text { Dentalina } \mathrm{sp} . \\
\text { Dentalina? } \mathrm{sp} . \\
\text { Eggerella sp. A } \\
\text { Elphidium cf. jenseni }\end{array}$ & & 2.91 & & & 1.12 & $\begin{array}{l}0.95 \\
0.47\end{array}$ & & 1.02 & 11.90 & & & & \\
\hline $\begin{array}{l}\text { Elphidium spp. } \\
\text { Elphidium subarcticum } \\
\text { Evolvocassidulina kuwanoi } \\
\text { Fissurina marginata } \\
\text { Fissurina orbignyana }\end{array}$ & & & & & $\begin{array}{l}1.12 \\
1.12\end{array}$ & $\begin{array}{l}0.95 \\
0.95\end{array}$ & 0.89 & 1.02 & & & & & \\
\hline $\begin{array}{l}\text { Fissurina sp. A } \\
\text { Fursenkoina sp. A } \\
\text { Gavelinopsis sp. } \\
\text { Glabratella suboperculosis } \\
\text { Globobulimina perversa }\end{array}$ & & & & 2.16 & 0.56 & 0.95 & 14.29 & $\begin{array}{l}2.73 \\
4.44\end{array}$ & & & & & \\
\hline $\begin{array}{l}\text { Globobulimina cf. perversa } \\
\text { Globobulimina pupoides } \\
\text { Globobulimina spp. } \\
\text { Globocassidulina globosa (s.1.) } \\
\text { Globocassidulina sp. A }\end{array}$ & & $\begin{array}{l}7.77 \\
1.94\end{array}$ & & $\begin{array}{l}2.88 \\
2.16 \\
0.72\end{array}$ & $\begin{array}{l}0.56 \\
4.47 \\
2.79 \\
0.56\end{array}$ & 1.42 & $\begin{array}{l}0.89 \\
2.68\end{array}$ & $\begin{array}{l}14.33 \\
0.34 \\
3.75\end{array}$ & $\begin{array}{l}2.38 \\
1.19\end{array}$ & & & $\begin{array}{l}1.22 \\
2.44\end{array}$ & \\
\hline $\begin{array}{l}\text { Glomospira sp. } \\
\text { Gyroidina orbicularis } \\
\text { Gyroidinoides planulatus } \\
\text { Gyroidinoides cf. planulatus } \\
\text { Hippocrepinella? }\end{array}$ & 10.53 & $\begin{array}{l}4.85 \\
5.83\end{array}$ & 14.29 & $\begin{array}{l}5.76 \\
3.60\end{array}$ & 13.41 & $\begin{array}{c}5.69 \\
10.90\end{array}$ & $\begin{array}{l}2.68 \\
3.57\end{array}$ & $\begin{array}{c}3.07 \\
15.36\end{array}$ & 3.57 & & 0.57 & 2.44 & \\
\hline $\begin{array}{l}\text { Hormosina spp. } \\
\text { Islandiella } \text { cf. compressa } \\
\text { Islandiella helenae } \\
\text { Islandiella sp. A } \\
\text { Lagena } \text { cf. apiopleura }\end{array}$ & & & & & 1.12 & & 3.57 & & & 0.64 & & & \\
\hline $\begin{array}{l}\text { Lenticulina spp. } \\
\text { Marginulina sp. } \\
\text { Martinottiella communis } \\
\text { Martinottiella cf. communis } \\
\text { Melonis nikobarense }\end{array}$ & 15.79 & $\begin{array}{l}0.97 \\
4.85\end{array}$ & 14.29 & 3.60 & $\begin{array}{l}20.11 \\
1.12\end{array}$ & $\begin{array}{l}0.47 \\
0.95 \\
1.90\end{array}$ & 0.89 & $\begin{array}{l}0.34 \\
0.34\end{array}$ & 3.57 & 10.22 & & & \\
\hline
\end{tabular}


Table 3 (continued).

\begin{tabular}{|c|c|c|c|c|c|c|c|c|c|c|c|c|c|}
\hline $\begin{array}{l}\text { Holes } 797 \mathrm{~B} \text { and } 797 \mathrm{C} \\
\text { Section } \\
\text { Interval }(\mathrm{cm})\end{array}$ & $\begin{array}{l}48 X-4 \\
56-60\end{array}$ & $\begin{array}{l}49 \mathrm{X}-2 \\
50-54\end{array}$ & $\begin{array}{l}49 X-4 \\
52-56\end{array}$ & $\begin{array}{l}51 X-1 \\
51-53\end{array}$ & $\begin{array}{l}51 X-3 \\
51-53\end{array}$ & $\begin{array}{l}51 X-5 \\
51-53\end{array}$ & $\begin{array}{l}52 X-1 \\
45-49\end{array}$ & $\begin{array}{l}52 X-3 \\
50-54\end{array}$ & $\begin{array}{l}52 X-6 \\
50-54\end{array}$ & $\begin{array}{l}797 \mathrm{C}- \\
2 \mathrm{R}-2 \\
28-32\end{array}$ & $\begin{array}{l}5 R-2 \\
76-80\end{array}$ & $\begin{array}{l}5 R-4 \\
39-43\end{array}$ & $\begin{array}{l}6 \mathrm{R}-1 \\
56-60\end{array}$ \\
\hline $\begin{array}{l}\text { Melonis pompilioides } \\
\text { Miliolinella sp. } \\
\text { Nodosaria? sp. } \\
\text { Nonionellina labradorica } \\
\text { Nonionella }\end{array}$ & & 0.97 & & 5.76 & 0.56 & $\begin{array}{l}0.47 \\
0.47\end{array}$ & 0.89 & 1.71 & & 0.32 & & & \\
\hline $\begin{array}{l}\text { Nonionella cf. miocenica } \\
\text { Nonionella stella } \\
\text { Oolina globosa } \\
\text { Oolina hexagona } \\
\text { Oolina? sp. }\end{array}$ & & & & 0.72 & 0.56 & 0.47 & 5.36 & 0.34 & & & & & \\
\hline $\begin{array}{l}\text { Oridorsalis umbonatus } \\
\text { Oridorsalis spp. } \\
\text { Parafissulina } \mathrm{sp} . \\
\text { Planodiscorbis sp. } \\
\text { Plectina nipponica }\end{array}$ & 10.53 & 1.94 & & & $\begin{array}{l}7.26 \\
0.56\end{array}$ & $\begin{array}{l}1.42 \\
0.47\end{array}$ & $\begin{array}{l}5.36 \\
1.79\end{array}$ & & 4.76 & 0.64 & & & \\
\hline $\begin{array}{l}\text { Plectina? sp. } \\
\text { Proteonina sp. } \\
\text { Proteonina? sp. } \\
\text { Pullenia bulloides } \\
\text { Pullenia quinqueloba }\end{array}$ & & 8.74 & & $\begin{array}{c}17.27 \\
0.72\end{array}$ & 3.35 & $\begin{array}{l}0.95 \\
0.95 \\
9.00 \\
0.47\end{array}$ & $\begin{array}{l}5.36 \\
3.57\end{array}$ & 13.65 & $\begin{array}{l}4.76 \\
1.19\end{array}$ & & & & \\
\hline $\begin{array}{l}\text { Pullenia salisburyi } \\
\text { Pullenia subcarinata } \\
\text { Pullenia cf. subcarinata } \\
\text { Pullenia } \text { sp. } \\
\text { Pullenia? sp. }\end{array}$ & 21.05 & 4.85 & & 2.16 & 1.12 & 3.79 & 3.57 & $\begin{array}{l}2.39 \\
0.68\end{array}$ & 1.19 & & & & \\
\hline $\begin{array}{l}\text { Pyrgo cf. vespertilio } \\
\text { Pyrgo murrhina } \\
\text { Pyrgo spp. } \\
\text { Quadrimorphina sp. } \\
\text { Quinqueloculina cf. seminula }\end{array}$ & & & & 0.72 & 0.56 & $\begin{array}{l}0.95 \\
2.37\end{array}$ & $\begin{array}{l}1.79 \\
0.89\end{array}$ & & & & & & \\
\hline $\begin{array}{l}\text { Quinqueloculina vulgaris } \\
\text { Quinqueloculina sp. A } \\
\text { Quinqueloculina sp. B } \\
\text { Quinqueloculina spp. } \\
\text { Quinqueloculina? sp. }\end{array}$ & & 2.91 & & & & $\begin{array}{l}2.37 \\
0.95 \\
0.95 \\
0.47\end{array}$ & & & & & & & \\
\hline $\begin{array}{l}\text { Recurvoides? sp. } \\
\text { Reophax excentricus } \\
\text { Reophax spp. } \\
\text { Reophax? sp. } \\
\text { Rhabdammina spp. }\end{array}$ & & & & & 0.56 & $\begin{array}{l}1.42 \\
0.95\end{array}$ & & + & $\begin{array}{r}2.38 \\
+ \\
+\end{array}$ & + & $\begin{array}{l}1.14 \\
0.57 \\
+\end{array}$ & + & + \\
\hline $\begin{array}{l}\text { Saccammina sp. } \\
\text { Saracenaria sp. } \\
\text { Schizammina } \text { sp. } \\
\text { Sphaeroidina cf. compacta } \\
\text { Sphaeroidina japonica }\end{array}$ & & & & & & 0.47 & $\begin{array}{l}0.89 \\
6.25\end{array}$ & & & + & & & + \\
\hline $\begin{array}{l}\text { Sphaeroidina cf. japonica } \\
\text { Spirosigmoilinella compressa } \\
\text { Spirosigmoilinella? sp. } \\
\text { Thalmannammina cf. parkerae } \\
\text { Tosaia hanzawai }\end{array}$ & & 0.97 & & 0.72 & 3.91 & 5.21 & 0.89 & & & $\begin{array}{l}9.90 \\
34.82\end{array}$ & $\begin{array}{l}12.50 \\
10.80\end{array}$ & $\begin{array}{l}2.44 \\
3.66\end{array}$ & 12.26 \\
\hline $\begin{array}{l}\text { Trifarina } \text { sp. } \\
\text { Triloculina sp. } \\
\text { Trochammina sp. } \\
\text { Uvigerina } \mathrm{cf} \text {. modeloensis } \\
\text { Uvigerina cf. segundoensis }\end{array}$ & & & & 0.72 & 0.56 & & 1.79 & & & & 0.57 & & \\
\hline $\begin{array}{l}\text { Uvigerina proboscidea } \\
\text { Uvigerina cf. proboscidea } \\
\text { Uvigerina sp. } \\
\text { Valvulineria cf. sadonica } \\
\text { Valvulineria masudai }\end{array}$ & & & & 2.88 & 1.12 & 10.43 & 0.89 & $\begin{array}{l}1.37 \\
18.43\end{array}$ & 4.76 & & & $\begin{array}{l}1.22 \\
4.88\end{array}$ & \\
\hline Valvulineria spp. & & 0.97 & & & & & & & & & & & \\
\hline Miscellaneous taxa & 15.79 & 0.97 & 28.57 & 13.67 & 2.79 & 7.11 & 10.71 & 1.02 & 26.19 & 9.90 & 15.34 & 1.22 & 24.52 \\
\hline
\end{tabular}


Table 3 (continued).

\begin{tabular}{|c|c|c|c|c|c|c|c|c|}
\hline $\begin{array}{l}\text { Holes } 797 \mathrm{~B} \text { and } 797 \mathrm{C} \\
\text { Section } \\
\text { Interval }(\mathrm{cm})\end{array}$ & $\begin{array}{l}8 R-1 \\
94-98\end{array}$ & $\begin{array}{l}11 R-1 \\
42-46\end{array}$ & $\begin{array}{l}18 R-1 \\
130-134\end{array}$ & $\begin{array}{l}22 R-5 \\
146-150\end{array}$ & $\begin{array}{l}23 \mathrm{R}-2 \\
14-18\end{array}$ & $\begin{array}{l}25 R-4 \\
85-89\end{array}$ & $\begin{array}{l}34 \mathrm{R}-6 \\
146-150\end{array}$ & $\begin{array}{l}41 \mathrm{R}-\mathrm{CC} \\
30-34\end{array}$ \\
\hline $\begin{array}{l}\text { Ammodiscus macilentus } \\
\text { Ammodiscus sp. A } \\
\text { Ammodiscus spp. } \\
\text { Ammodiscus tenuis } \\
\text { Ammosphaeroidina } \mathrm{sp} .\end{array}$ & 2.08 & & 3.23 & & & & & \\
\hline $\begin{array}{l}\text { Ammovertellina } \\
\text { Astrononion } \mathrm{sp} . \\
\text { Bathysiphon spp. } \\
\text { Brizalina } \text { sp. } \\
\text { Buccella } \text { cf. kuromatsunaiensis }\end{array}$ & + & 6.58 & + & + & + & + & + & + \\
\hline $\begin{array}{l}\text { Bulimina cf. rostrata } \\
\text { Bulimina sp. } \\
\text { Bulimina striata } \\
\text { Bulimina cf. striata } \\
\text { Chilostomella oolina }\end{array}$ & & & & & & & & \\
\hline $\begin{array}{l}\text { Cibicides cf. refulgens } \\
\text { Cibicides sp. } \\
\text { Cibicidoides? sp. } \\
\text { Cibicidoides bradyi } \\
\text { Cibicidoides sp. }\end{array}$ & & & & & & & & \\
\hline $\begin{array}{l}\text { Cibicidoides sp. A } \\
\text { Cibicidoides sp. B } \\
\text { Cibicidoides wuellerstorfi } \\
\text { Cribrostomoides? sp. } \\
\text { Cribrostomoides cf. crassimargo }\end{array}$ & & & & 7.14 & 50.00 & & & \\
\hline $\begin{array}{l}\text { Cyclammina? sp. } \\
\text { Cyclammina cancellata } \\
\text { Cyclammina orbicularis } \\
\text { Cyclammina pusilla } \\
\text { Cyclammina } \mathrm{sp} . \mathrm{A}\end{array}$ & $\begin{array}{l}2.50 \\
65.83\end{array}$ & $\begin{array}{l}2.63 \\
63.16\end{array}$ & 12.90 & 10.71 & & & & \\
\hline $\begin{array}{l}\text { Dentalina insecta } \\
\text { Dentalina sp. } \\
\text { Dentalina? sp. } \\
\text { Eggerella } \mathrm{sp} . \mathrm{A} \\
\text { Elphidium cf. jenseni }\end{array}$ & & & & & & & & \\
\hline $\begin{array}{l}\text { Elphidium spp. } \\
\text { Elphidium subarcticum } \\
\text { Evolvocassidulina kawanoi } \\
\text { Fissurina marginata } \\
\text { Fissurina orbignyana }\end{array}$ & & & & & & & & \\
\hline $\begin{array}{l}\text { Fissurina } \text { sp. A } \\
\text { Fursenkoina sp. A } \\
\text { Gavelinopsis sp. } \\
\text { Glabratella suboperculosis } \\
\text { Globobulimina perversa }\end{array}$ & & & & & & & & \\
\hline $\begin{array}{l}\text { Globobulimina cf. perversa } \\
\text { Globobulimina pupoides } \\
\text { Globobulimina spp. } \\
\text { Globocassidulina globosa (s.L.) } \\
\text { Globocassidulina sp. A }\end{array}$ & & & & & & & & \\
\hline $\begin{array}{l}\text { Glomospira sp. } \\
\text { Gyroidina orbicularis } \\
\text { Gyroidinoides planulatus } \\
\text { Gyroidinoides cf. planulatus } \\
\text { Hippocrepinella? }\end{array}$ & 0.42 & & & & & & & \\
\hline $\begin{array}{l}\text { Hormosina spp. } \\
\text { Islandiella cf. compressa } \\
\text { Islandiella helenae } \\
\text { Islandiella sp. A } \\
\text { Lagena cf. apiopleura }\end{array}$ & 0.83 & & & & & & & \\
\hline $\begin{array}{l}\text { Lenticulina } \text { spp. } \\
\text { Margimulina } \mathrm{sp} . \\
\text { Martinottiella communis } \\
\text { Martinottiella cf. communis } \\
\text { Melonis nikobarense }\end{array}$ & 19.17 & & & & & & & \\
\hline
\end{tabular}


Table 3 (continued).

\begin{tabular}{|c|c|c|c|c|c|c|c|c|}
\hline $\begin{array}{l}\text { Holes 797B and 797C } \\
\text { Section } \\
\text { Interval }(\mathrm{cm})\end{array}$ & $\begin{array}{l}8 R-1 \\
94-98\end{array}$ & $\begin{array}{l}11 R-1 \\
42-46\end{array}$ & $\begin{array}{l}18 R-1 \\
130-134\end{array}$ & $\begin{array}{l}22 R-5 \\
146-150\end{array}$ & $\begin{array}{l}23 R-2 \\
14-18\end{array}$ & $\begin{array}{l}25 \mathrm{R}-4 \\
85-89\end{array}$ & $\begin{array}{l}34 \mathrm{R}-6 \\
146-150\end{array}$ & $\begin{array}{l}41 \mathrm{R}-\mathrm{CC} \\
30-34\end{array}$ \\
\hline \multicolumn{9}{|l|}{$\begin{array}{l}\text { Melonis pompilioides } \\
\text { Miliolinella sp. } \\
\text { Nodosaria? sp. } \\
\text { Nonionellina labradorica } \\
\text { Nonionella }\end{array}$} \\
\hline \multicolumn{9}{|l|}{$\begin{array}{l}\text { Nonionella cf. miocenica } \\
\text { Nonionella stella } \\
\text { Oolina globosa } \\
\text { Oolina hexagona } \\
\text { Oolina? sp. }\end{array}$} \\
\hline \multicolumn{9}{|l|}{$\begin{array}{l}\text { Oridorsalis umbonatus } \\
\text { Oridorsalis spp. } \\
\text { Parafissulina sp. } \\
\text { Planodiscorbis sp. } \\
\text { Plectina nipponica }\end{array}$} \\
\hline $\begin{array}{l}\text { Plectina? sp. } \\
\text { Proteonina sp. } \\
\text { Proteonina? sp. } \\
\text { Pullenia bulloides } \\
\text { Pullenia quinqueloba }\end{array}$ & & & $\begin{array}{l}3.23 \\
3.23\end{array}$ & & & & & \\
\hline \multicolumn{9}{|l|}{$\begin{array}{l}\text { Pullenia salisburyi } \\
\text { Pullenia subcarinata } \\
\text { Pullenia cf. subcarinata } \\
\text { Pullenia sp. } \\
\text { Pullenia? sp. }\end{array}$} \\
\hline \multicolumn{9}{|l|}{$\begin{array}{l}\text { Pyrgo cf. vespertilio } \\
\text { Pyrgo murrhina } \\
\text { Pyrgo spp. } \\
\text { Quadrimorphina } \mathrm{sp} \text {. } \\
\text { Quinqueloculina } \mathrm{cf} \text {. seminula }\end{array}$} \\
\hline \multicolumn{9}{|l|}{$\begin{array}{l}\text { Quinqueloculina vulgaris } \\
\text { Quinqueloculina sp. A } \\
\text { Quinqueloculina sp. B } \\
\text { Quinqueloculina } \mathrm{spp} . \\
\text { Quinqueloculina? sp. }\end{array}$} \\
\hline $\begin{array}{l}\text { Recurvoides? sp. } \\
\text { Reophax excentricus } \\
\text { Reophax spp. } \\
\text { Reophax? sp. } \\
\text { Rhabdammina spp. }\end{array}$ & + & & & + & 50.00 & 20.00 & & \\
\hline \multicolumn{9}{|l|}{$\begin{array}{l}\text { Saccammina sp. } \\
\text { Saracenaria sp. } \\
\text { Schizammina sp. } \\
\text { Sphaeroidina cf. compacta } \\
\text { Sphaeroidina japonica }\end{array}$} \\
\hline $\begin{array}{l}\text { Sphaeroidina cf. japonica } \\
\text { Spirosigmoilinella compressa } \\
\text { Spirosigmoilinella? sp. } \\
\text { Thalmannammina cf. parkerae } \\
\text { Tosaia hanzawai }\end{array}$ & 0.42 & & 16.13 & 7.14 & & & & \\
\hline \multicolumn{9}{|l|}{$\begin{array}{l}\text { Trifarina sp. } \\
\text { Triloculina sp. } \\
\text { Trochammina sp. } \\
\text { Uvigerina cf. modeloensis } \\
\text { Uvigerina } \text { cf. segundoensis }\end{array}$} \\
\hline \multicolumn{9}{|l|}{$\begin{array}{l}\text { Uvigerina proboscidea } \\
\text { Uvigerina cf. proboscidea } \\
\text { Uvigerina sp. } \\
\text { Valvulineria } \text { cf. sadonica } \\
\text { Valvulineria masudai }\end{array}$} \\
\hline \multicolumn{9}{|l|}{ Valvulineria spp. } \\
\hline Miscellaneous taxa & 8.75 & 27.63 & 61.29 & 75.00 & & 80.00 & & \\
\hline
\end{tabular}




\section{Holes 794A}

\section{and 794B}

\section{Epochs}

Plio.

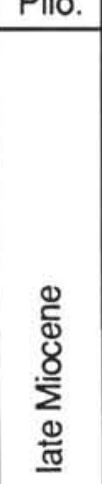
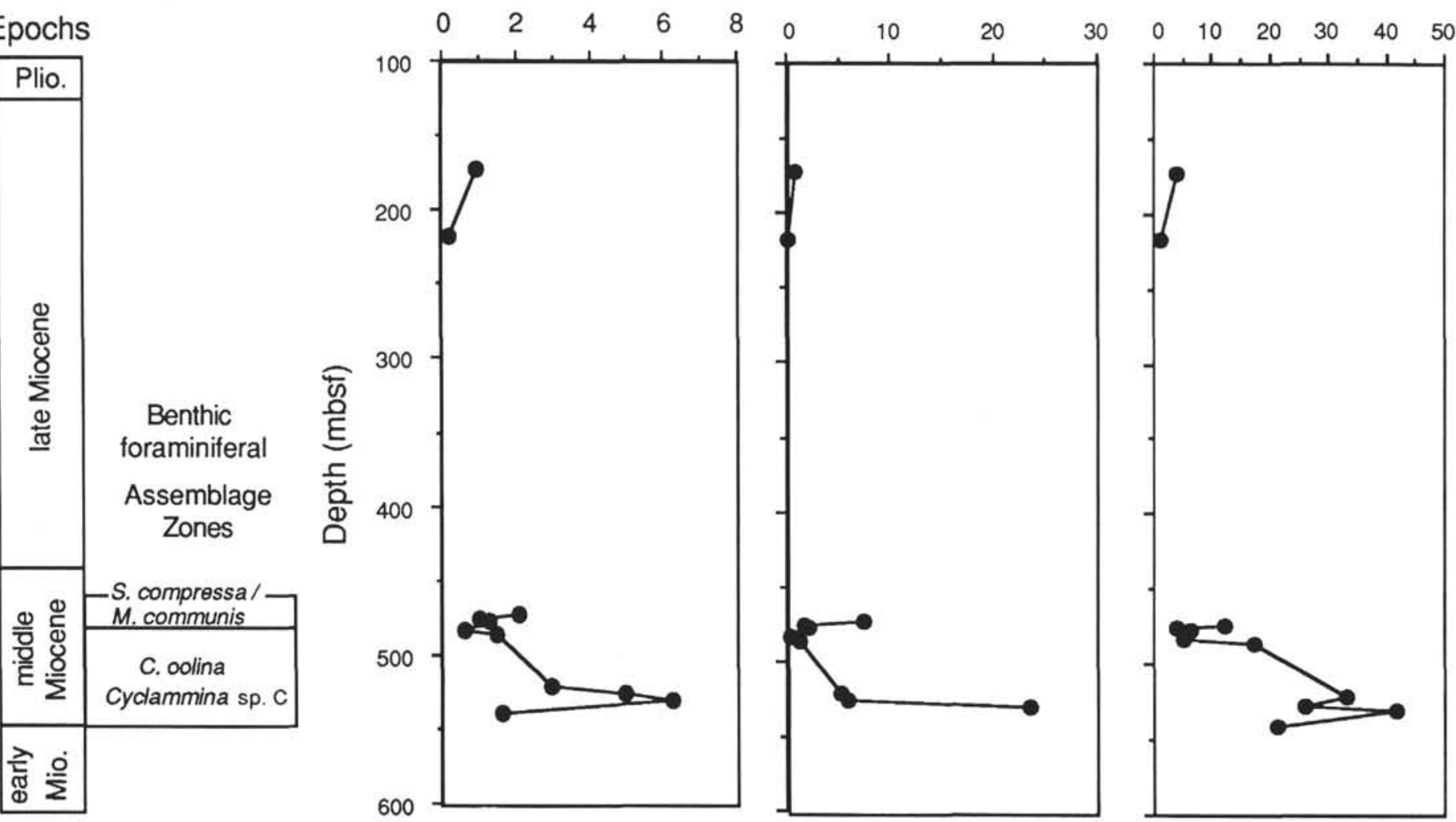

Individuals $/ \mathrm{cm}^{3} / \mathrm{k}$.y.

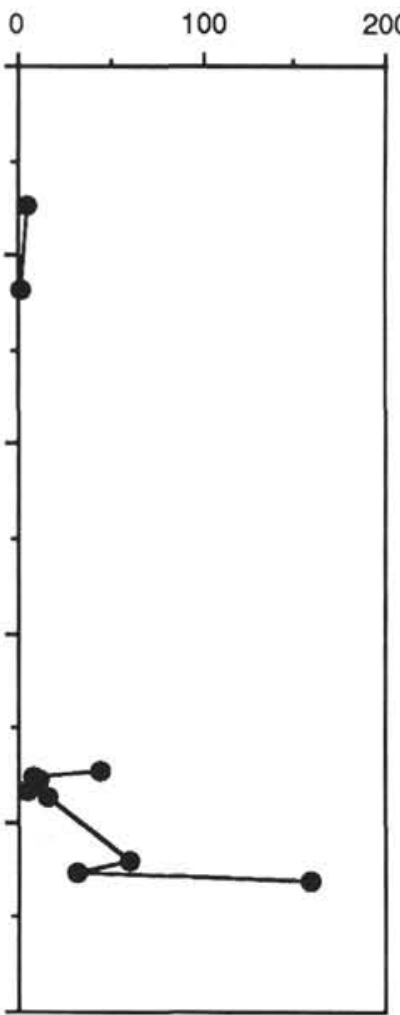

Figure 7. Species diversity in terms of species number, species number per $\mathrm{cm}^{3}$, and species number per k.y. at Site 794. 


\section{Holes 794A} and 794B

\section{Calcareous foraminifers (\%) Agglutinated foraminifers (\%)}

\section{Epochs}

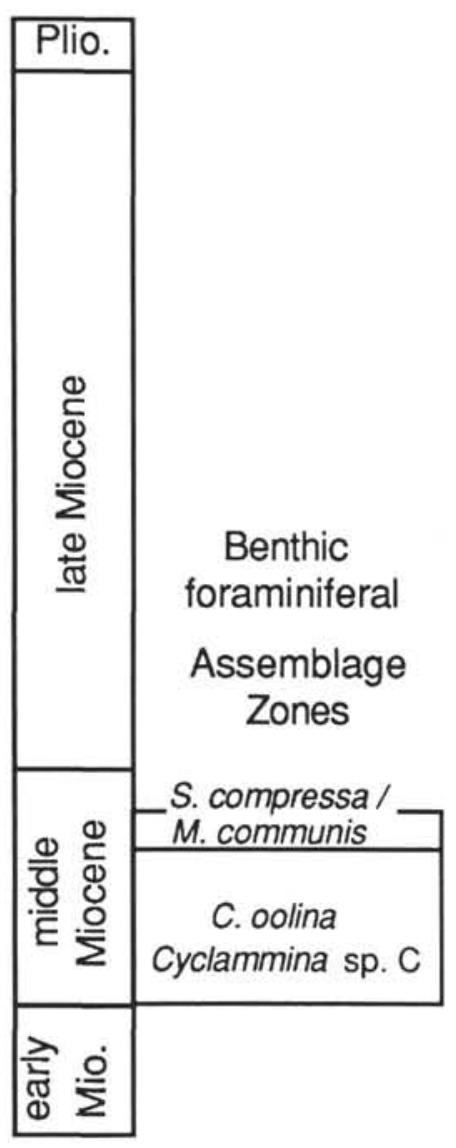

$\begin{array}{llllllllllllll}0 & 10 & 20 & 30 & 40 & 50 & 60 & 40 & 50 & 60 & 70 & 80 & 90 & 100\end{array}$

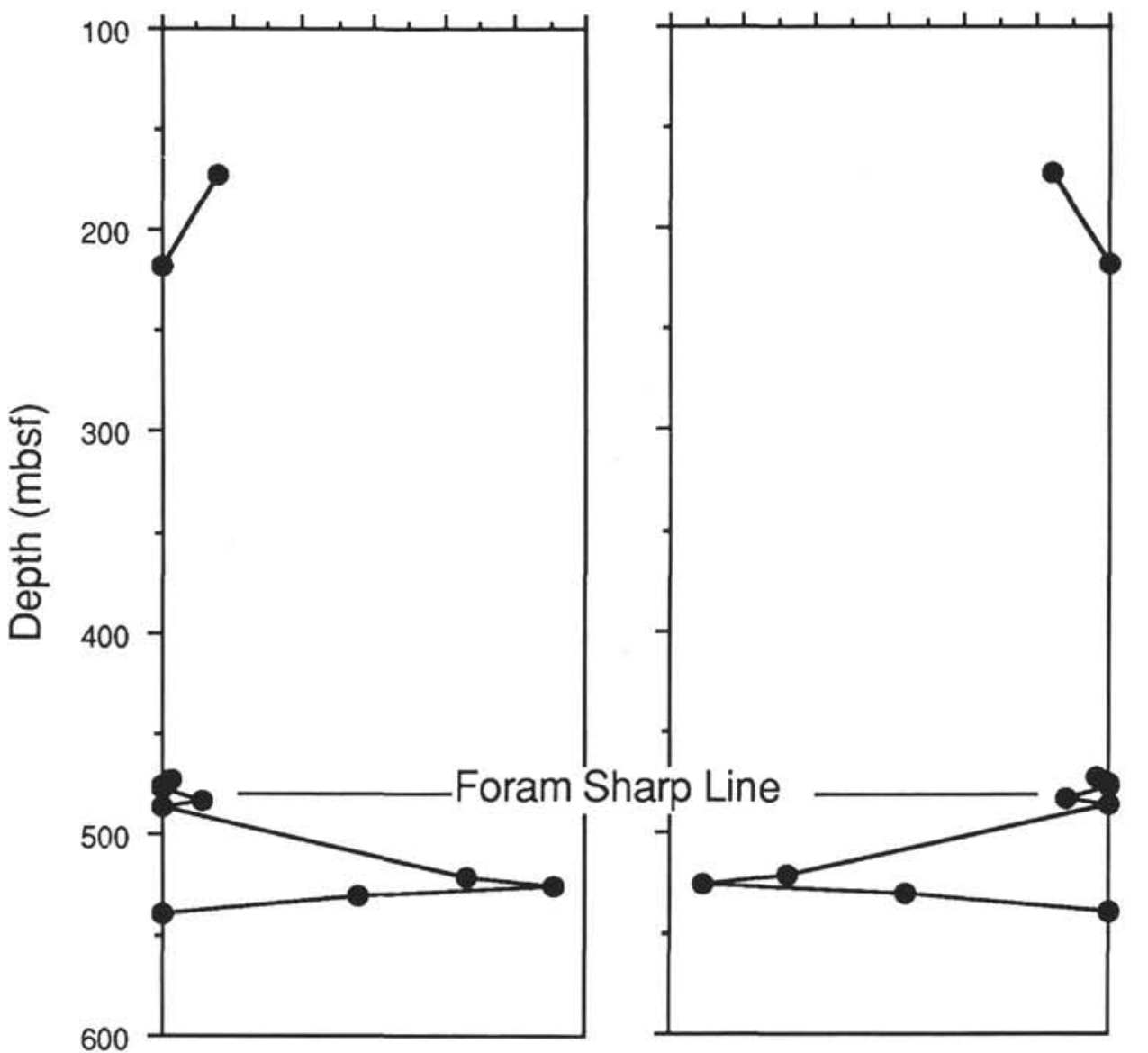

Figure 8. Stratigraphic distribution of calcareous and agglutinated foraminifers at Site 794.

different age of the FSL between the Japan and Yamato basins is not due to a time lag alone. For these reasons, the FSL at 14-15 Ma is here called the first FSL and that at 11.2 Ma is the second FSL.

Appearance of the FSL at Sites 794, 795, and 797 reveals that anoxic bottom water formed throughout the Sea of Japan in middle Miocene time, which can be explained by a silled basin model applied for the FSL from Southwest Honshu (Nomura, 1989, in press). This event may also relate to a global extinction event of deep-water benthic foraminifers recognized by Berggren and Miller (1989). Both of these ideas offer possible explanations for the nature of the FSL. However, on the basis of the distribution of the first FSL restricted to the back-arc region, it should be related to the tectonic movement of the Islands arc.

\section{BENTHIC FORAMINIFERAL ZONES}

\section{Site 794}

On the basis of the occurrence of calcareous foraminifers and their abundance, two assemblage zones are recognized at Site 794 (Figs. 2 and 5). The first, the Chilostomella oolina/Cyclammina sp. C Assemblage Zone, consists of the lower part of the middle Miocene and is characterized by an abundant occurrence of $C$. oolina, Cyclammina sp. C, and Thalmannammina cf. parkerae. The upper boundary of this zone is defined by the disappearance of $C$. oolina, Nonionella mio- cenica, Globocassidulina sp. C, and Cyclammina pusilla between 127-794B-19R-4, 37-39 cm (477.17 mbsf), and 127-794B-20R-1, $139-143 \mathrm{~cm}$ (483.39 mbsf).

The second, the Spirosigmoilinella compressa/Martinottiella communis Assemblage Zone, is characterized by an abundant occurrence of Cyclammina? sp., M. communis, and $S$. compressa. The upper boundary of this zone is not defined because of insufficient materials in the upper middle Miocene to upper Miocene. The lower boundary of this zone is defined by the disappearance of calcareous foraminifers.

\section{Site 795}

Three assemblage zones are recognized at Site 795 (Figs. 3 and 9).

Martinottiella communis Assemblage Zone: This zone is characterized by the presence of agglutinated foraminifers such as $M$. communis, Eggerella bradyi, and Cribrostomoides cf. crassimargo. The upper boundary of this zone is defined by the horizon just below the appearance of Cibicidoides bradyi and Oridorsalis umbonatus at Sample 127-795B-29R-3, 116-120 cm (639.46 mbsf).

Oridorsalis umbonatus/Cibicidoides wuellerstorfi Assemblage Zone: This zone is characterized by the interval of abundant calcareous foraminifers including $C$. wuellerstorfi, Gyroidina orbicularis, Gyroidinoides planulatus, and Oridorsalis umbonatus. The upper boundary of this zone is defined by the disappearance 


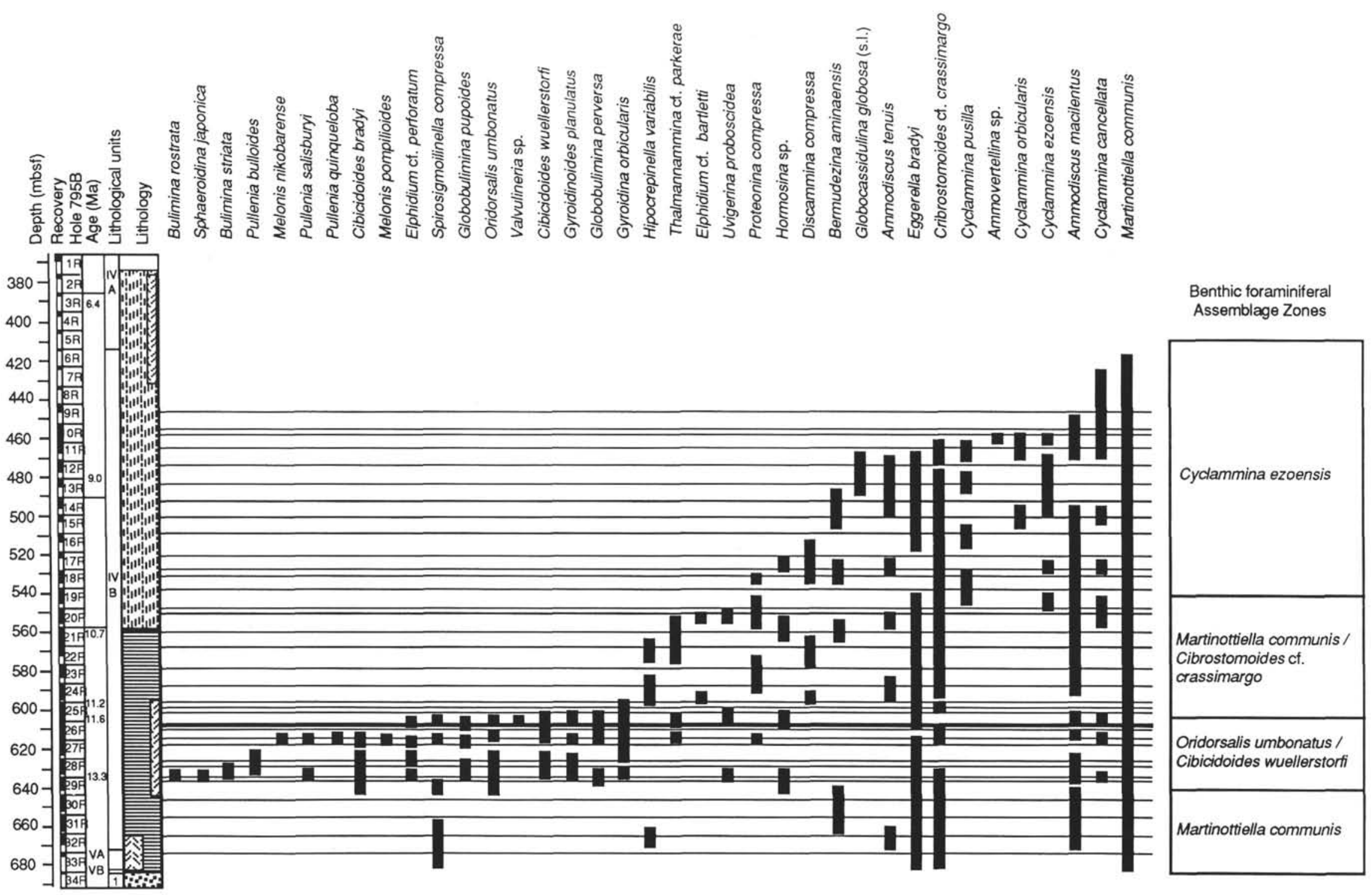

Figure 9. Stratigraphic distribution of benthic foraminifers from Site 795. 


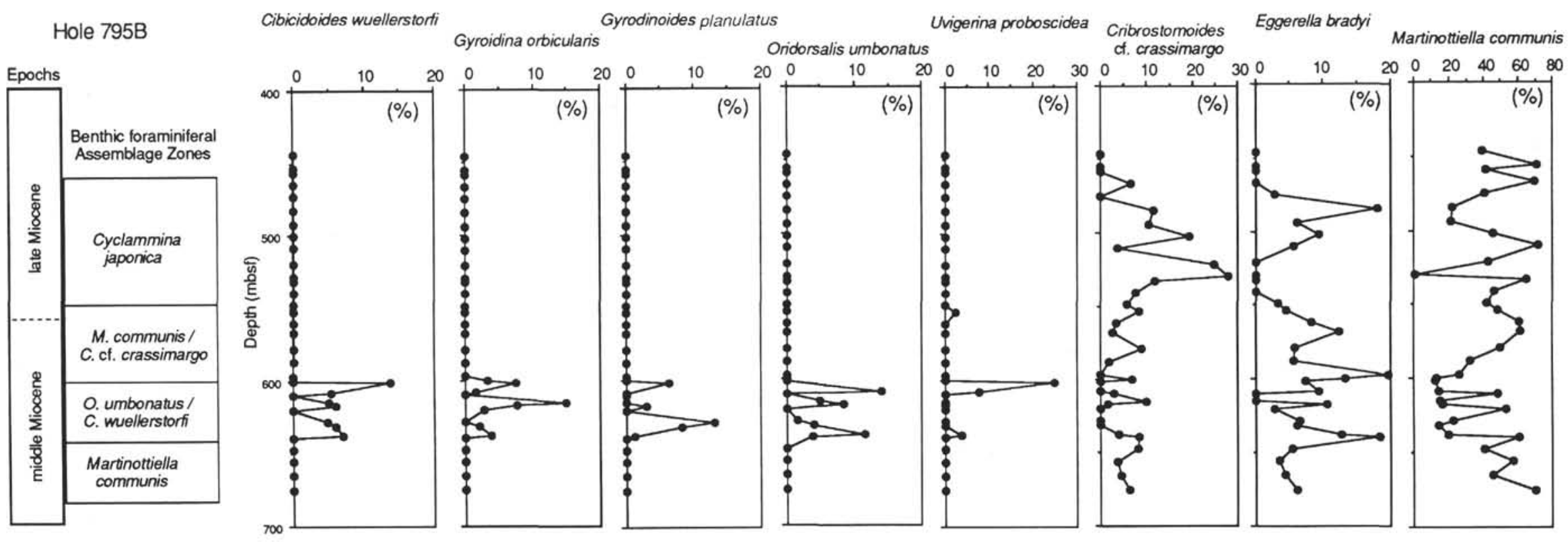

Figure 10. Frequency distribution of dominant benthic foraminifers from Site 795 in terms of percent of total population. 
Hole 795B

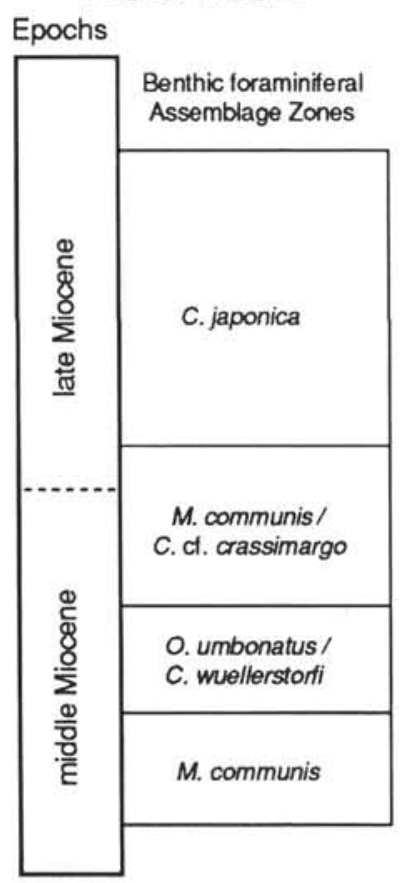

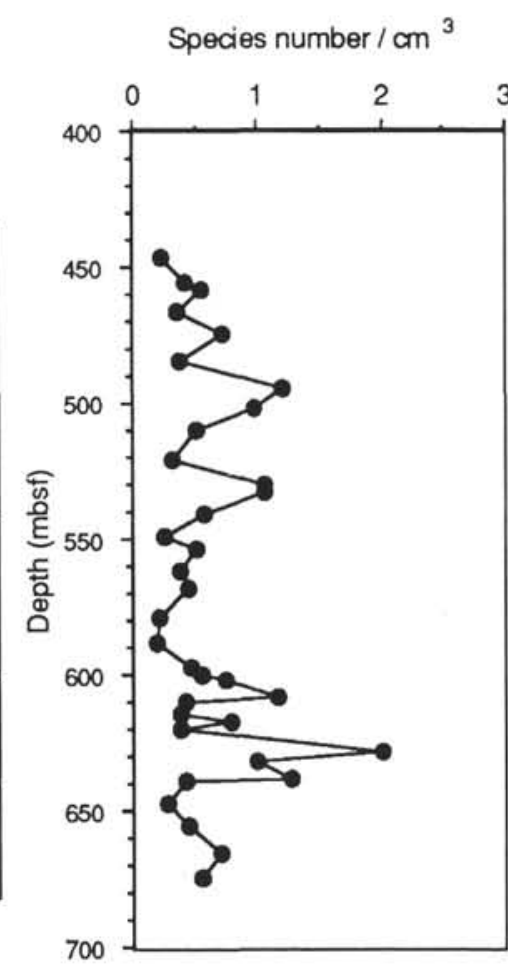

Species number $/ \mathrm{cm}^{3} / \mathrm{k} . y$.

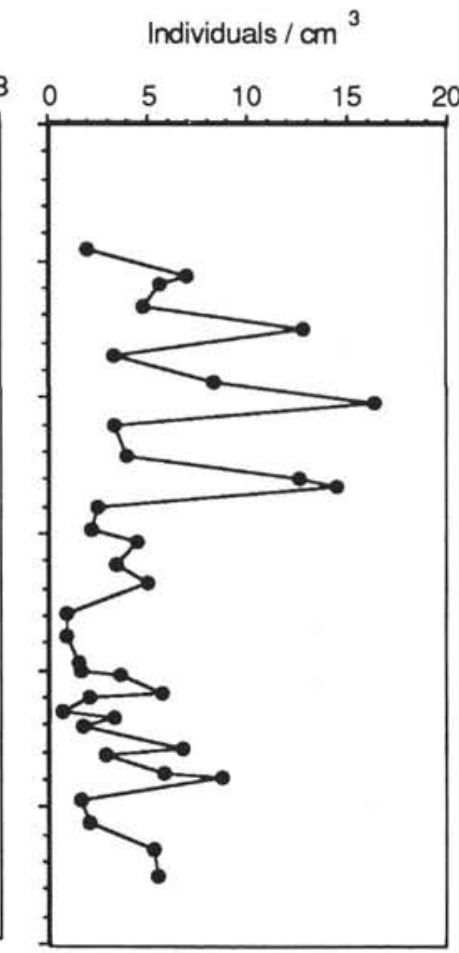

Individuals $/ \mathrm{cm}^{3} /$ k.y.
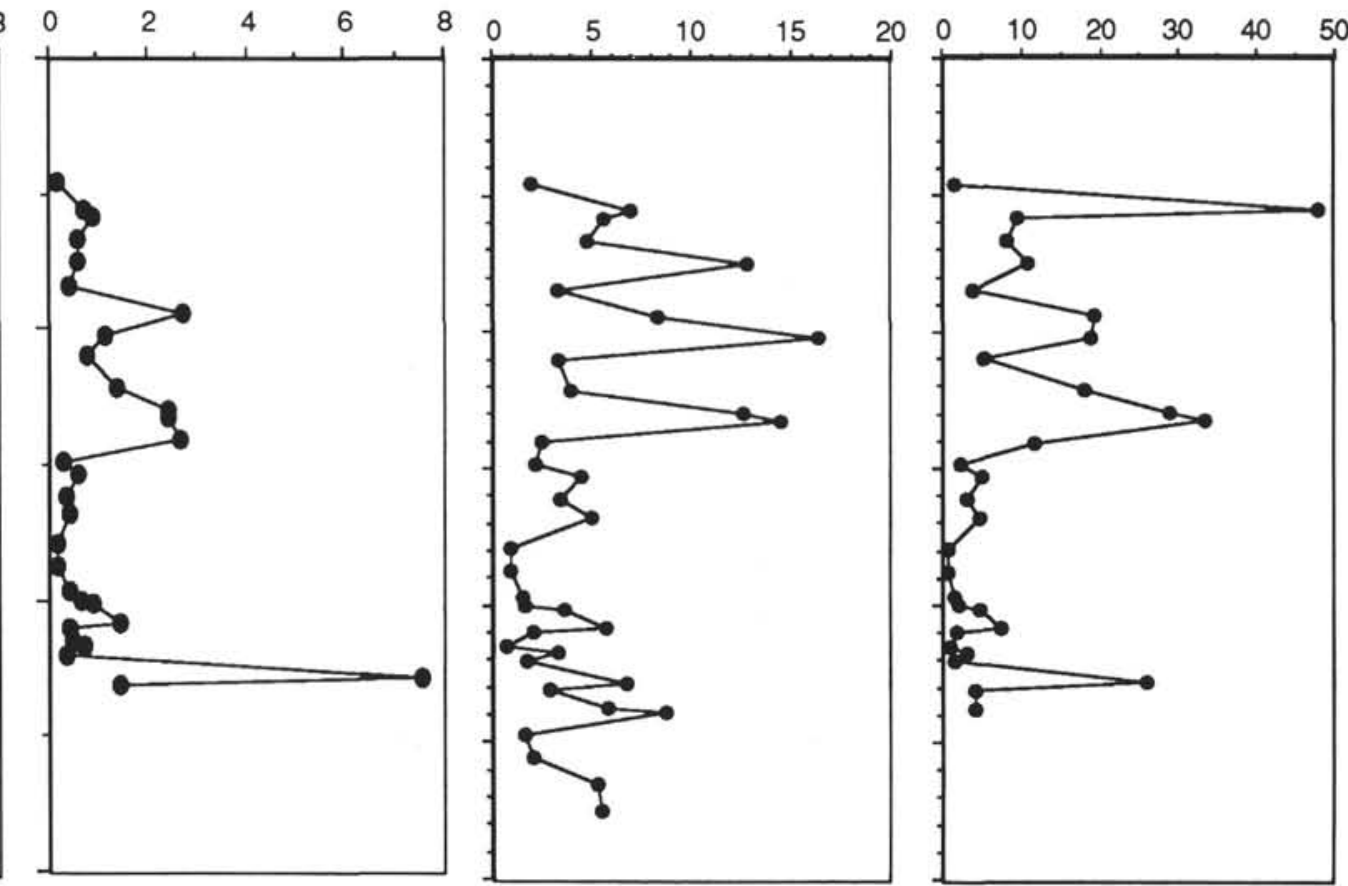

Figure 11. Species diversity in terms of species number, species number per $\mathrm{cm}^{3}$, and species number per k.y. from Site 795 . 
of $O$. umbonatus and C. wuellerstorfi between Samples 127-795B25R-3, 43-46 cm (600.13 mbsf), and 795B-25R-4, 23-26 cm (601.43 mbsf).

Martinottiella communis/Cribrostomoides cf. crassimargo Assemblage Zone: This zone consists of agglutinated foraminifers in association with very limited calcareous foraminifers. The base of this zone is defined by the disappearance of $O$. umbonatus and $C$, wuellerstorfi. The upper boundary is defined by the horizon below the appearance of Cyclammina ezoensis at Sample 127-795B-19R-2, $42-43 \mathrm{~cm}$ (540.62 mbsf).

Cyclammina ezoensis Assemblage Zone: This zone is defined by common occurrence of Cyclammina ezoensis and well-developed agglutinated foraminifers at the interval of $127-795 \mathrm{~B}-19 \mathrm{R}-2,42-43$ $\mathrm{cm}$ (540.62 mbsf), to $127-795 \mathrm{~B}-10 \mathrm{R}-5,50-52 \mathrm{~cm}$ (458.5 mbsf).

\section{Site 797}

Seven benthic foraminiferal assemblage zones are recognized at Site 797 (Figs. 4, 13, and 14).

First barren interval: First barren interval develops in the range of Sample 127-797C-41R-CC (856.14 mbsf) to 797C-23R-2, 14-18 cm (696.24 mbsf). Broken and badly preserved Bathysiphon? sp. in Sample 127-797C-41R-CC indicates an early Miocene marine environment.
Cyclammina sp. A/Cyclammina? sp. Assemblage Zone: This zone is characterized by the occurrence of Cyclammina sp. A, Cyclammina? sp., Thalmannammina cf. parkerae, and Ammodiscus macilentus. In general, foraminiferal diversities are low in this zone. The upper boundary of this zone is defined by the appearance of Cibicidoides bradyi, Globobulimina perversa, and Pullenia bulloides in Sample 127-797B-52X-6, 50-54 cm (492.5 mbsf).

Gyroidina orbicularis/Gyroidinoides planulatus Assemblage Zone: This zone is characterized by a high diversity of calcareous foraminifers. The upper boundary of this zone is defined by the disappearance of several calcareous foraminifers such as Cibicidoides sp. B, Uvigerina cf. modeloensis, and Valvulineria masudai between Samples 127-797B-49X-4, 52-56 cm (460.52 mbsf), and 127-797B$51 \mathrm{X}-1,51-53 \mathrm{~cm}$ (475.41 mbsf).

Cibicidoides wuellerstorfi Assemblage Zone: This zone is defined by an abundant occurrence of $C$. wuellerstorfi, Cyclammina sp. A, and Pullenia bulloides and is characterized by a high number of calcareous foraminifers. The upper boundary of this zone is defined by the disappearance of foraminifers between Samples 127-797B-46X-1, 28-32 cm, and 127-797B-47X-1, 45-49 $\mathrm{cm}$ (426.98-436.55 mbsf).

Second barren interval: This interval ranges from the horizon below Sample 127-797B-41X-1, 34-38 cm (379.34 mbsf), to the

\section{Hole 795B}

\section{Epochs}

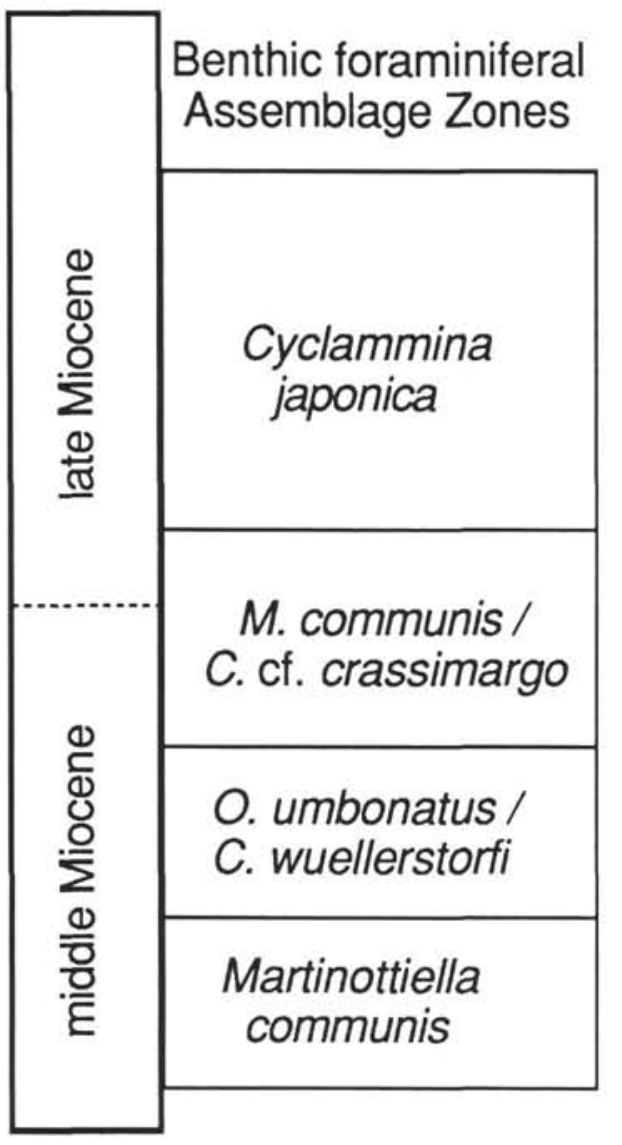

Calcareous foraminifers (\%)

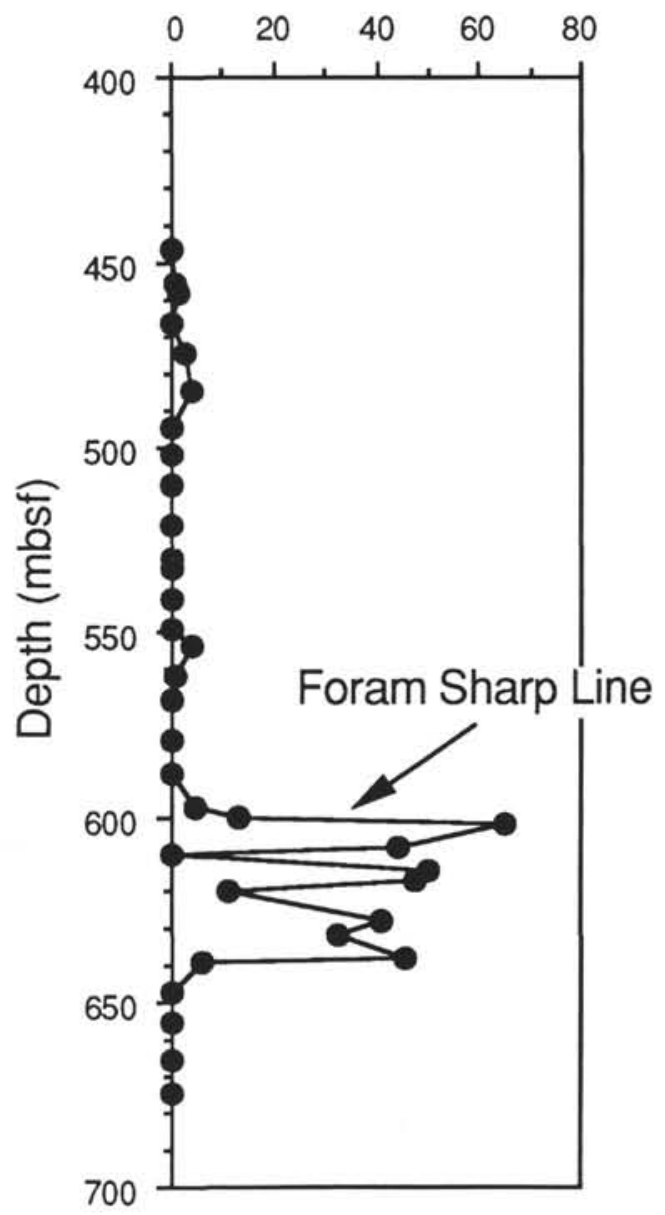

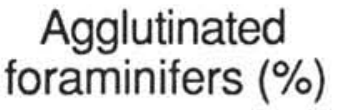

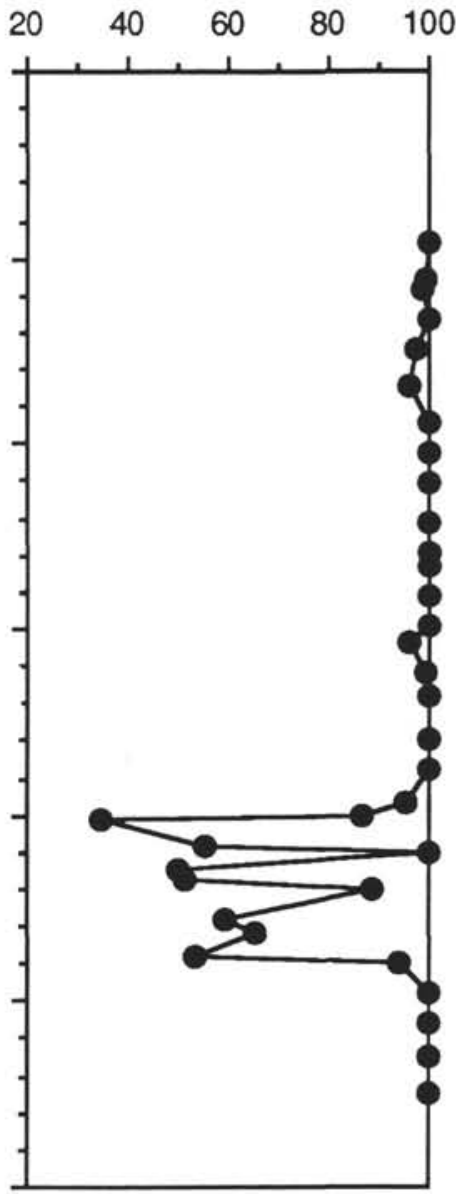

Figure 12. Stratigraphic distribution of calcareous and agglutinated foraminifers at Site 795. 


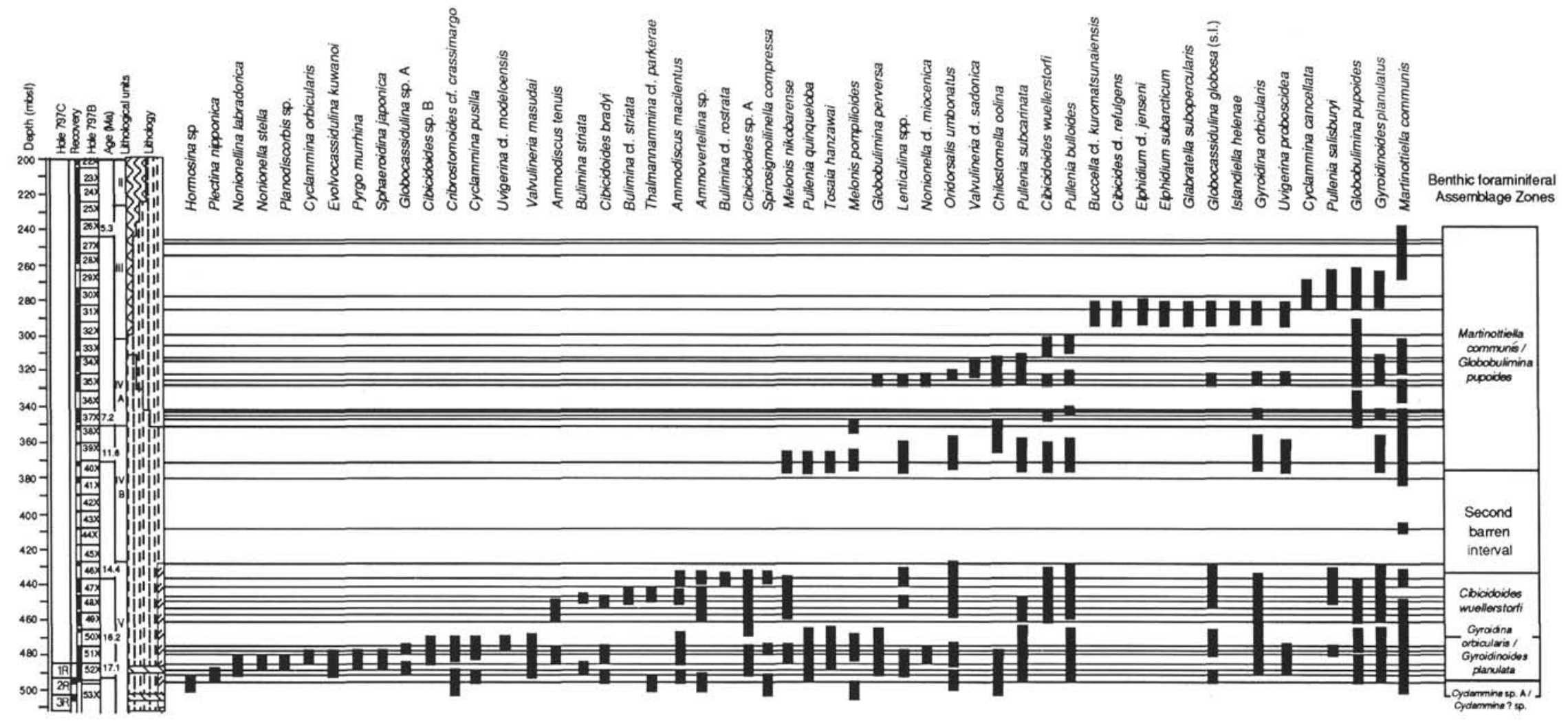

Figure 13. Middle to upper Miocene stratigraphic distribution of benthic foraminifers from Site 797. 


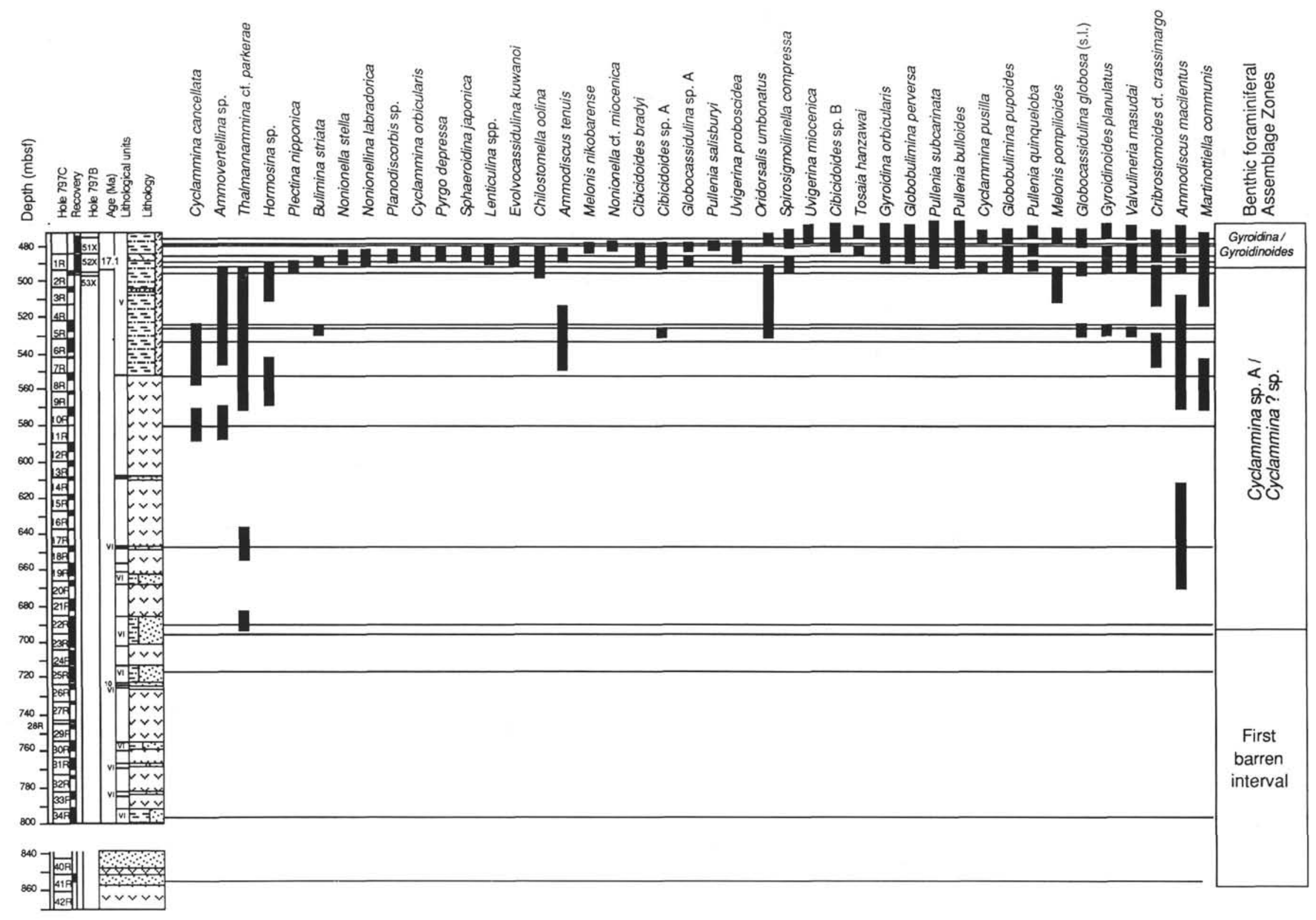

Figure 14. Lower to lower middle Miocene stratigraphic distribution of benthic foraminifers from Site 797. 
Holes 797B, 797C

Epochs

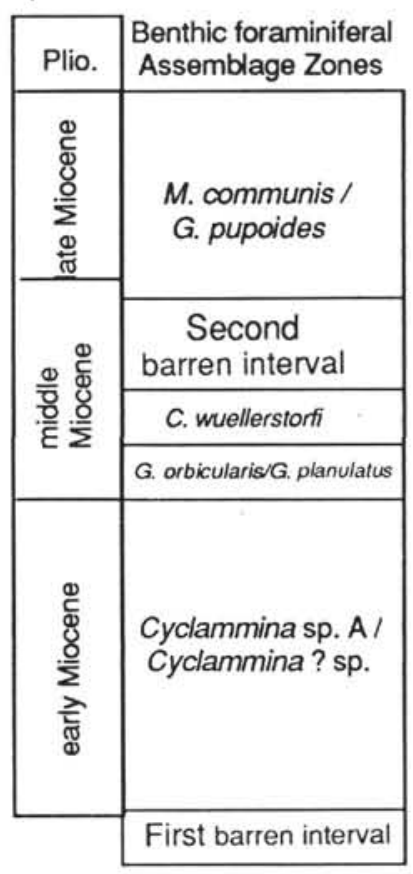

\section{Epochs}

\begin{tabular}{|c|c|}
\hline Plio. & $\begin{array}{l}\text { Benthic foraminiferal } \\
\text { Assemblage Zones }\end{array}$ \\
\hline 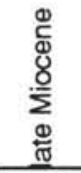 & $\begin{array}{l}\text { M. communis } \\
\text { G. pupoides }\end{array}$ \\
\hline \multirow{3}{*}{ 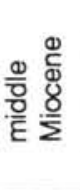 } & $\begin{array}{c}\text { Second } \\
\text { barren interval }\end{array}$ \\
\hline & C. wuellerstorfi \\
\hline & G. orbicularis/G. planulatus \\
\hline 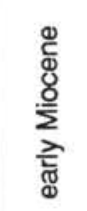 & $\begin{array}{l}\text { Cyclammina sp. A / } \\
\text { Cyclammina? sp. }\end{array}$ \\
\hline & First barren interval \\
\hline
\end{tabular}

Chilostomella oolina

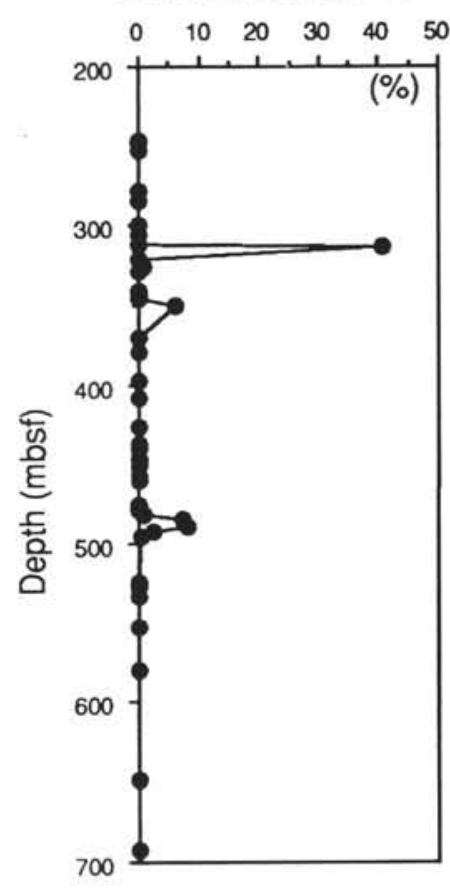

Globobulimina perversa

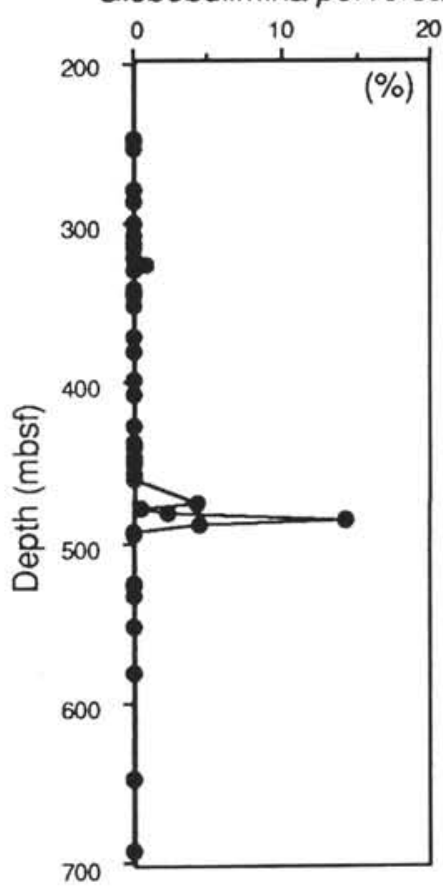

Cibicidoides sp. A Cibicidoides wuellerstorfi
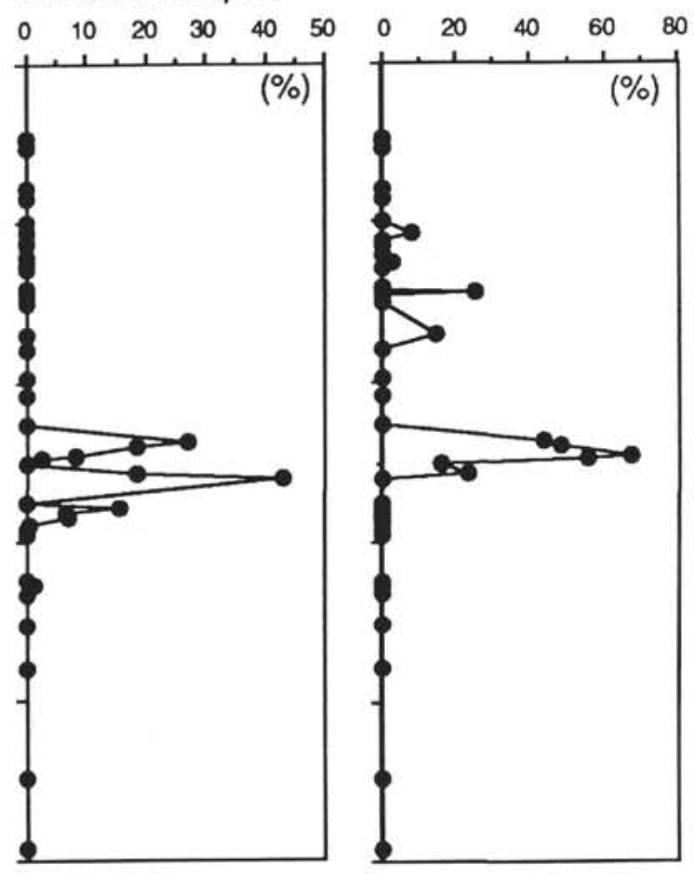

Globobulimina pupoides
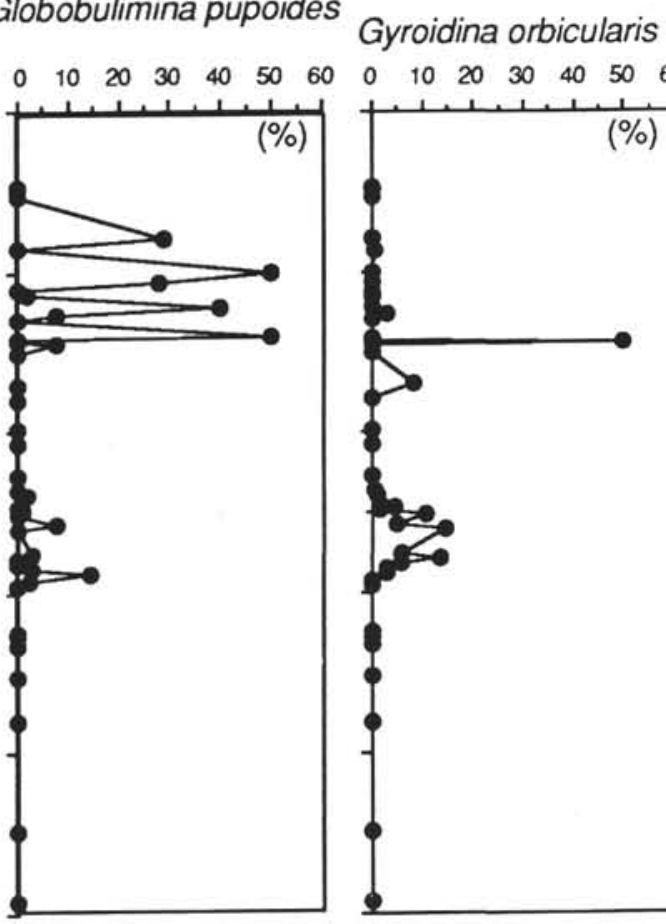
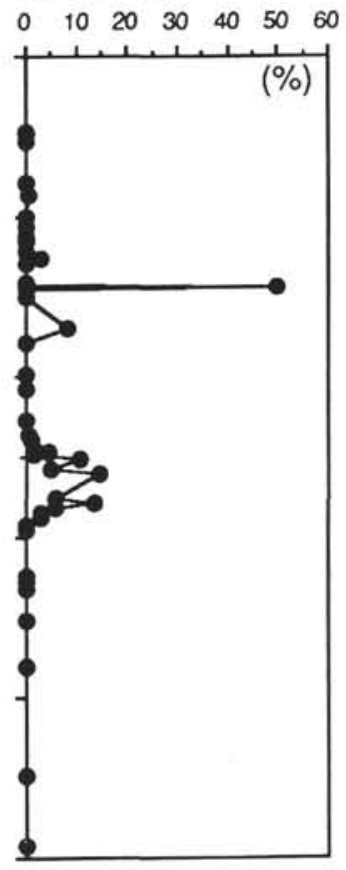

Figure 15. Frequency distribution of dominant benthic foraminifers from Site 797 in terms of percent of total benthic foraminifer population.

horizon above Sample 127-797B-47X-1, 45-49 cm (436.66 mbsf). Occurrence of benthic foraminifers is very limited; only Martinottiella communis is found in this interval.

Martinottiella communis/Globobulimina pupoides Assemblage Zone: The lower boundary of this zone is defined by the appearance of both agglutinated and calcareous foraminifers such as Uvigerina proboscidea, Cibicidoides wuellerstorfi, and Martinottiella commu- nis in Sample 127-797B-40X-2, 35-39 cm (370.31 mbsf). This zone is principally characterized by low numbers of species and specimens of agglutinated foraminifers.

The correlation of these benthic zones is shown in Figure 20 along with correlation of benthic zones from Southwest Honshu and Northeast Honshu. Matsunaga's Hopkinsina morimachiensis Zone was originally defined by planktonic foraminifers, but Maiya (1978) re- 
Holes 797B, 797C

Epochs

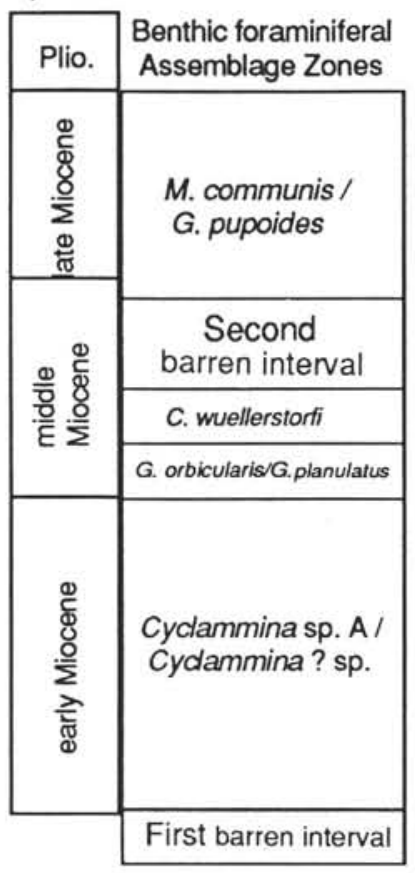

Epochs

\begin{tabular}{|c|c|}
\hline Plio. & $\begin{array}{l}\text { Benthic foraminiferal } \\
\text { Assemblage Zones }\end{array}$ \\
\hline 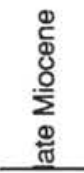 & $\begin{array}{l}\text { M. communis / } \\
\text { G. pupoides }\end{array}$ \\
\hline \multirow{3}{*}{ 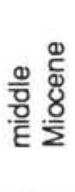 } & $\begin{array}{l}\text { Second } \\
\text { barren interval }\end{array}$ \\
\hline & C. wuellerstorfi \\
\hline & G. orbicularis/G. planulatus \\
\hline \multirow[t]{2}{*}{ 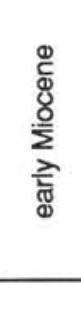 } & $\begin{array}{l}\text { Cyclammina sp. A/ } \\
\text { Cydammina? sp. }\end{array}$ \\
\hline & First barren interval \\
\hline
\end{tabular}

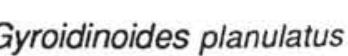

Oridorsalis umbonatus

\section{Pullenia bulloides}
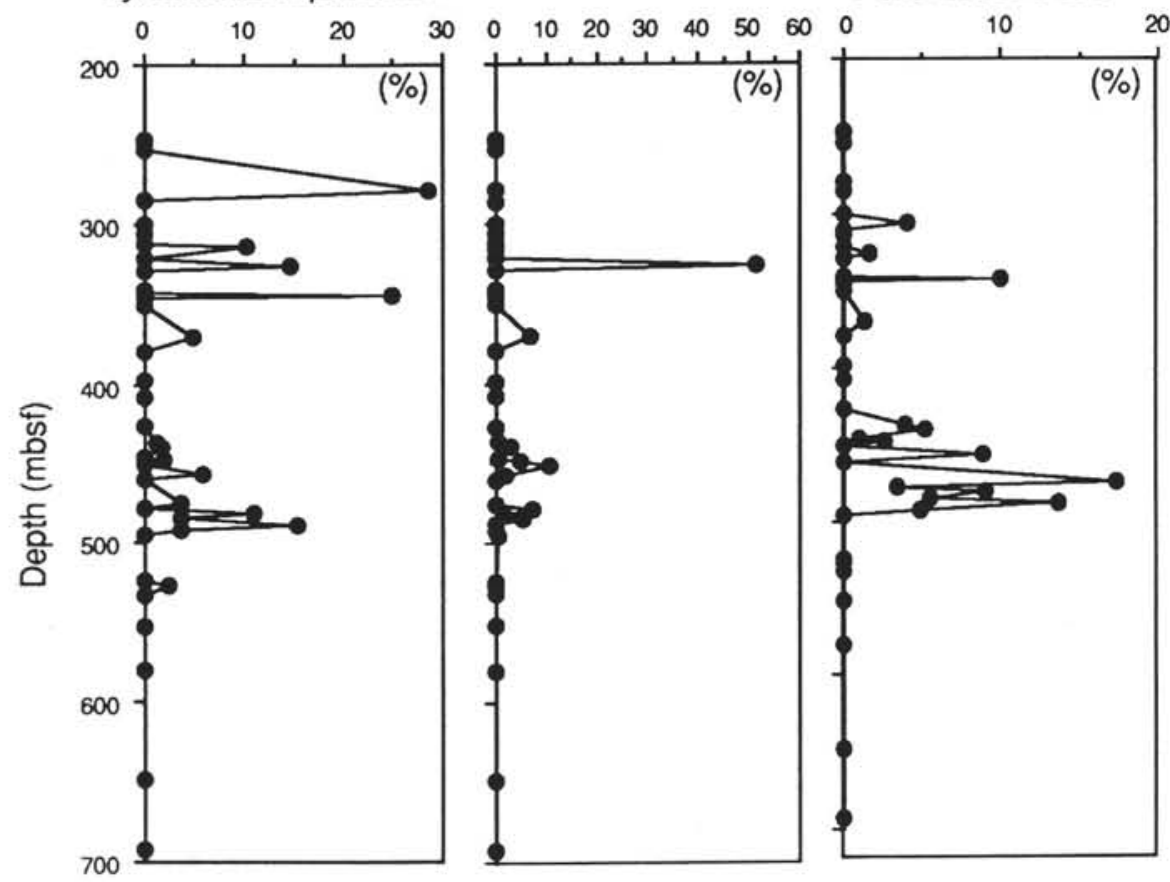

\section{Uvigerina proboscidea}

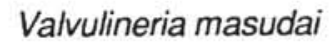

Cyclammina? sp.
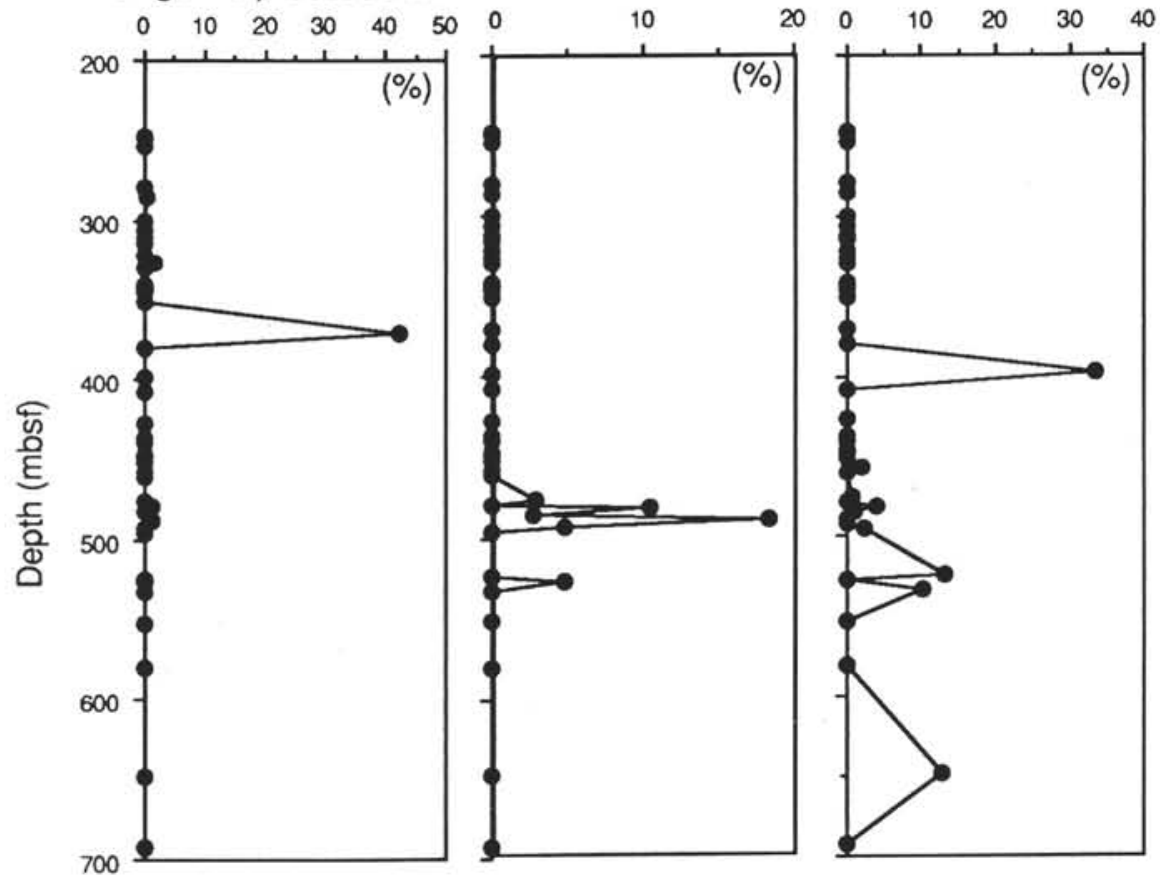

Figure 15 (continued).

vised it and correlated with his planktonic foraminiferal zone in the Niigata area.

\section{CLUSTER ANALYSES}

Seventy-eight samples from three sites were grouped into seven clusters in this study. The result of cluster analysis is shown in Figure
21 and the stratigraphic distributions of these groups are shown in Figure 22.

The horizon having the highest foraminiferal diversity below the FSL is mainly characterized by $\mathrm{C}$ or $\mathrm{E}$ clusters. $\mathrm{C}$ and $\mathrm{E}$ clusters occur alternately in two zones at Site 797 and one zone at Site 795. The D cluster is also characterized by a high abundance of calcareous foraminifers, but it consists primarily of reworked fauna. Other clusters such as B, F, and G are characterized by the agglutinated 


\section{Holes 797B, 797C}

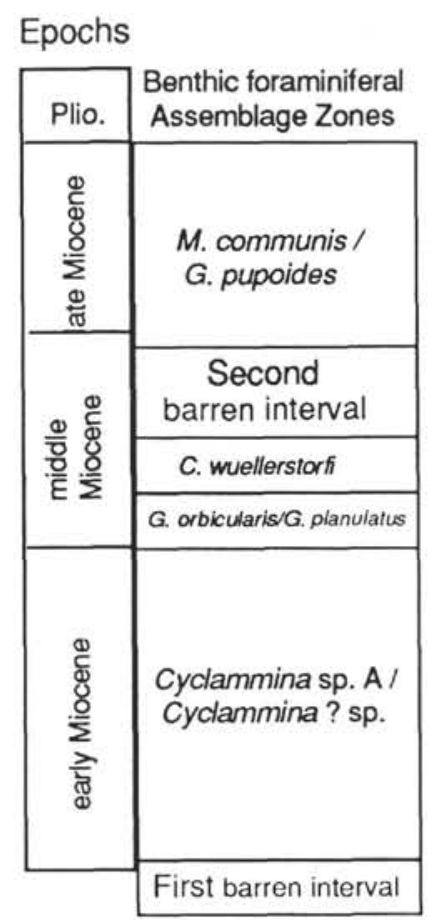

\section{Thalmannammina}

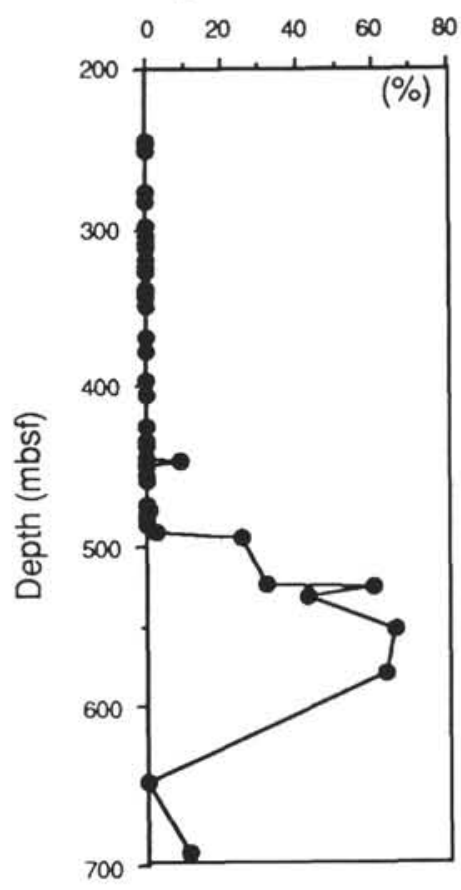
cf. parkerae

Martinottiella communis

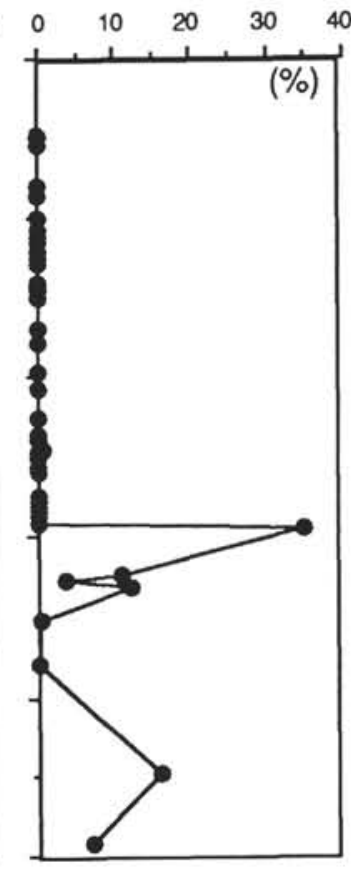

$\begin{array}{llllll}0 & 20 & 40 & 60 & 80 & 100\end{array}$

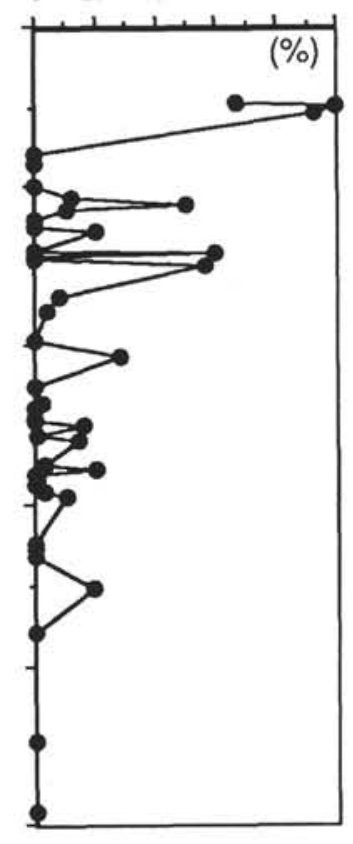

Figure 15 (continued).

foraminifers, although the A cluster contains a few calcareous foraminifers.

It should be noted that the $\mathrm{C}$ and $\mathrm{E}$ clusters at Site 795 appear during 11.2-13.3 Ma, an age that corresponds to the development of the second barren interval at Site 797 in the Yamato Basin. The second FSL at Site 795 is correlated with the top of the second barren interval at Site 797. Alternatively, B cluster does not appear at Site 797 prior to $14.3 \mathrm{Ma}$. This may be due to the local difference of deep-sea environment and suggests that paleoceanographic condition of earlier stages of the Sea of Japan is differentiated not only within the Yamato Basin but also between the Yamato and Japan Basins. These sorts of benthic distributional patterns depend primarily on local conditions, as noted by Boltovskoy (1987)

\section{DISCUSSION}

\section{Timing of the Foram Sharp Line and Paleoceanography of the Sea of Japan}

As is well known, tropical to subtropical shallow-marine faunas and subsequent deep-water faunas developed on pre-Tertiary basement and/or lower Miocene nonmarine sediments in the area of the Honshu arc. Therefore, contrasting early to early middle Miocene faunas are present at the Sea of Japan ODP sites and the onshore Sea of Japan coastal regions, despite the presence of similar faunas around the margins of the Sea of Japan. These differences largely reflect the different tectonic histories and water depths of these two fundamentally different areas of the Sea of Japan.

The planktonic foraminiferal Globigerinoides sicanus/Praeorbulina glomerata and Globorotalia peripheroronda/Globorotalia quinifalcata Zones of Maiya (1978) proposed for the Sea of Japan side of Northeast Honshu are correlated with the standard planktonic foraminifer N8 to N9 Zones. Maiya's two zones are also correlated with the lower two-thirds of the benthic foraminifer Hopkinsina morimachiensis Zone of Matsunaga (1963)(Fig. 19). In this zone, paleotopographic irregularity has been noted in the Niigata and Akita regions of northem Honshu. The Hopkinsina morimachiensis Zone includes diversified Hopkinsina species in association with the correlative shallower faunas, which include Miogypsina, Operculina, Nephrolepidina, and Ammonia tochigiensis. The deeper fauna in the H. morimachiensis Zone is characterized by the nominate taxon along with Cyclammina spp., "Haplophragmoides" spp., Martinottiella communis, Uvigerina proboscidea, Gyroidina orbicularis, Melonis pomplioides, Cibicidoides wuellerstorfi, Pullenia bulloides, and Stilostomella lepidula (Maiya, 1978; Matoba, 1984), which are considered to represent water depths of $1500-2000 \mathrm{~m}$ (Matoba, 1981). Even deeper water depths ( $>3500 \mathrm{~m}, 1500-2000 \mathrm{~m}$, and 2000-3000 $\mathrm{m})$ have been estimated for the inland area of Northeast Honshu (Guber and Ohmoto, 1978; Kitazato, 1979; Matoba, 1983). Thus, a range of paleodepths was formed during Zones N8-9 in the Northeast Honshu arc coincident with volcanic activity. In contrast, Miocene benthic foraminifers from the Southwest Honshu arc usually indicate sequential deepening of sedimentary basins. In the Bihoku Group of the inland area of Southwest Honshu, three zones of the MiogypsinaOperculina, the Hanzawaia tagaensis/Heterolepa praecincta, and the Uvigerina segundoensis s.l. are recognized from lower to upper horizons (Tai, 1959; Nomura, in press). Although these zones are not precisely dated because of limited age-indicative microfossils, it is clear that differential vertical movement in the basin commenced in the Hanzawaia/Heterolepa Zone assigned to upper N8 to N9 zones. These areas continue to deepen in the Uvigerina Zone and a barren interval ( $=$ the 2 nd barren interval at Site 797; Fig. 20$)(\sim 300 \mathrm{~m}$ in paleodepth), coincident with the uplift of the Chugoku Backbone Range. Uplift of the Backbone Range prevented Pacific Deep Water from entering the paleo-Sea of Japan. The first FSL corresponds to the timing of the formation of stagnant bottom water in the inland area of Southwest Honshu (Nomura, 1989). The agglutinated fauna formed 


\section{Holes 797B and 797C}

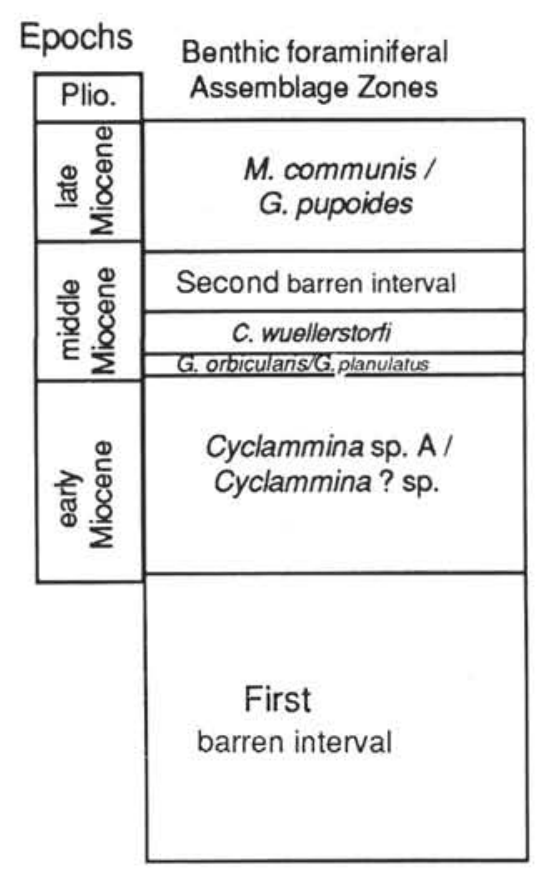

Species number/ $\mathrm{cm}^{3}$

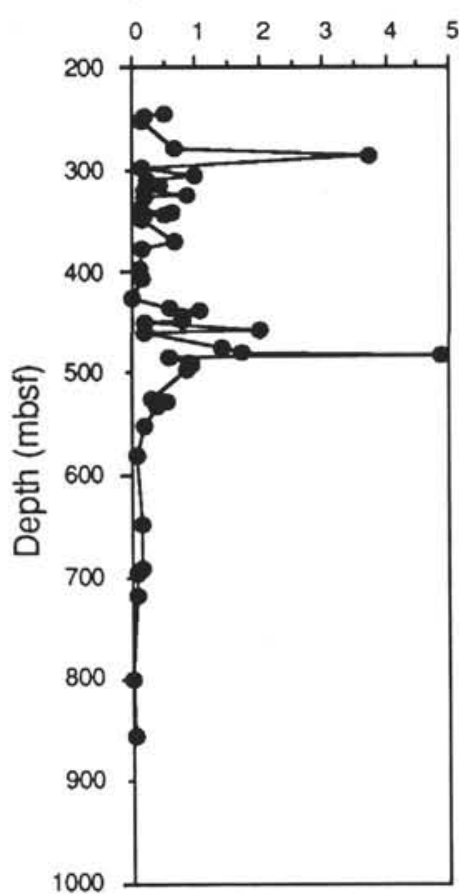

Species number $/ \mathrm{cm}^{3} / \mathrm{k} . \mathrm{y}$.

Individuals $/ \mathrm{cm}^{3}$

Individuals $/ \mathrm{cm}^{3} / \mathrm{k} . \mathrm{y}$.
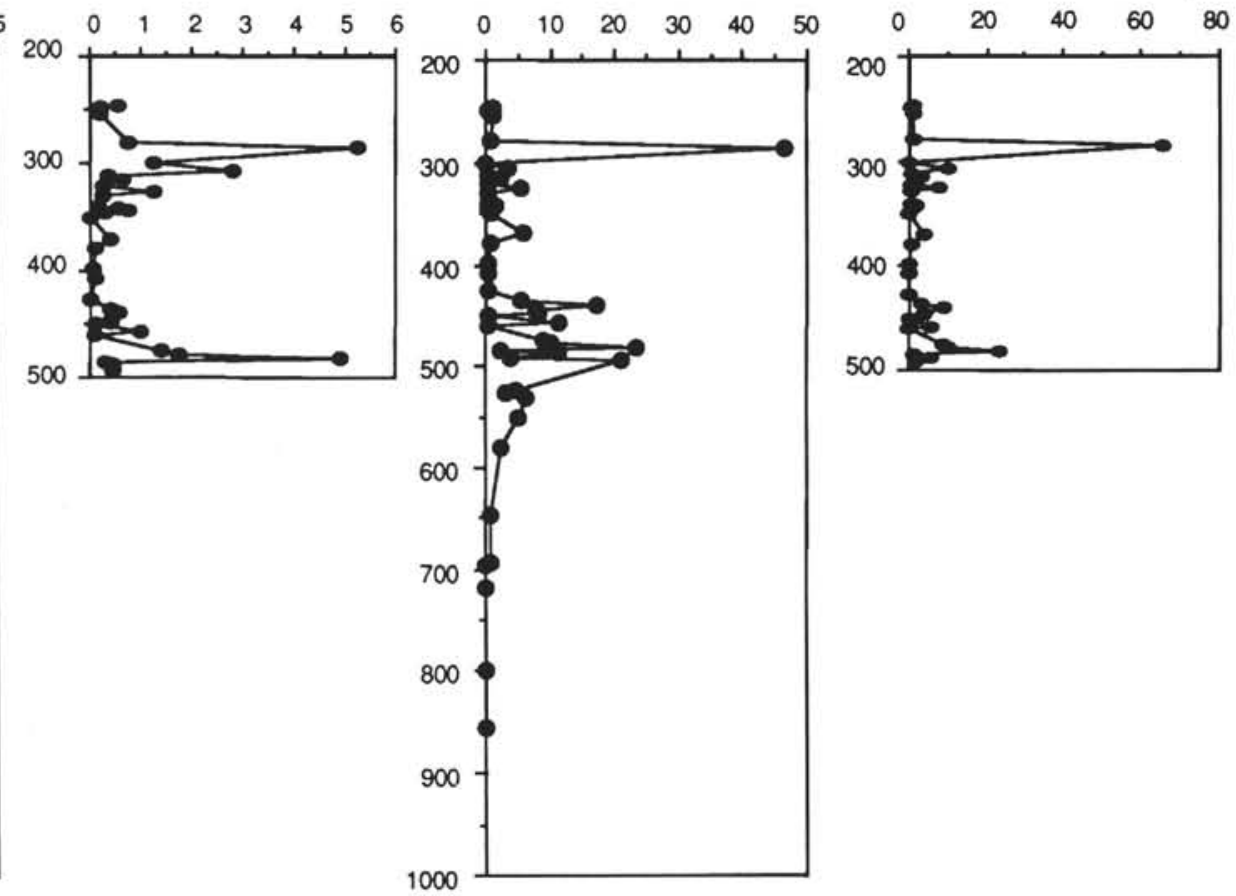

Figure 16. Species diversity in terms of species number, species number per $\mathrm{cm}^{3}$, and species number per k.y. from Site 797. 


\section{Holes 797B and 797C}

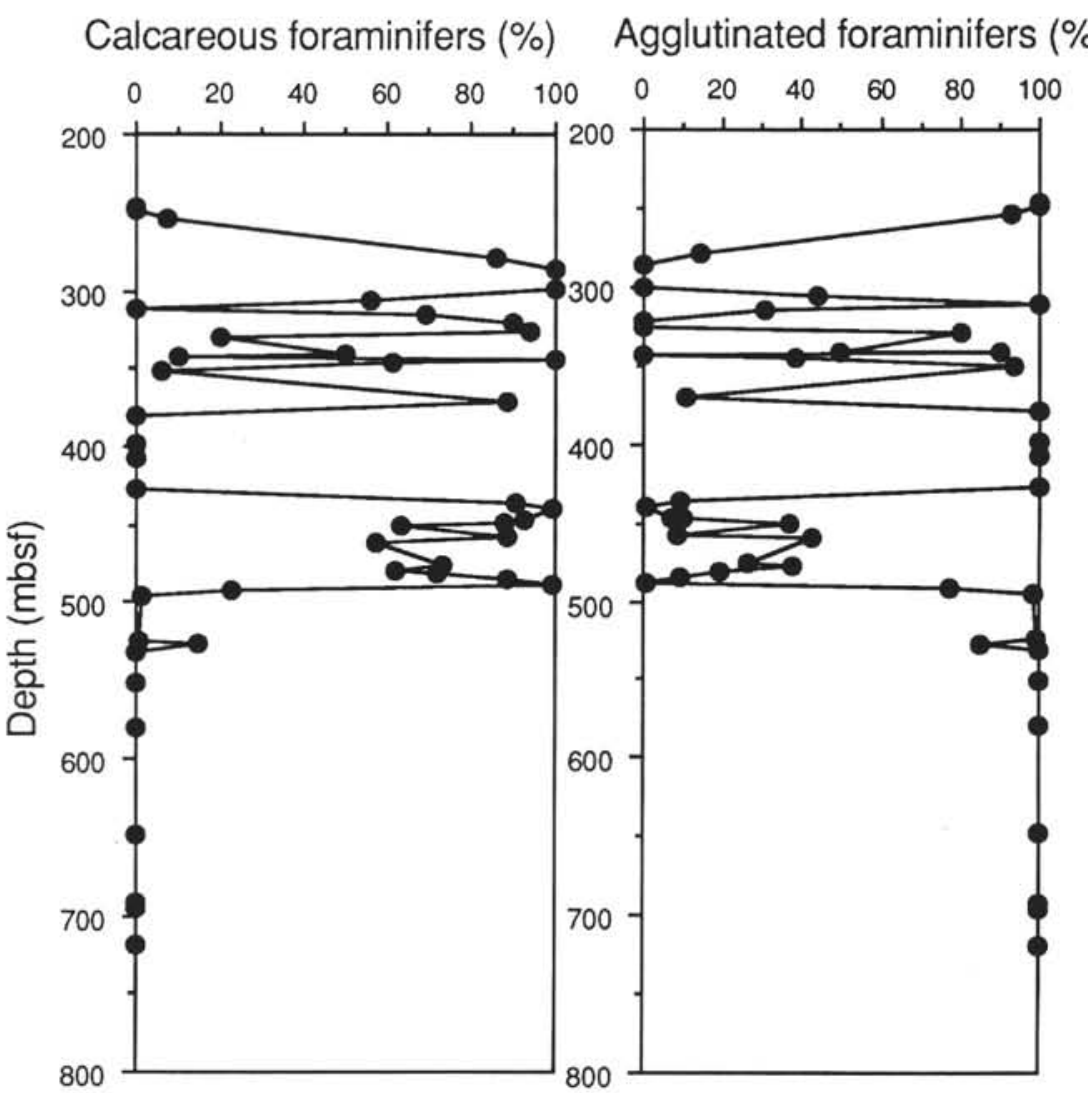

Figure 17. Stratigraphic distribution of calcareous and agglutinated foraminifers at Site 797.

in the Shimane Peninsula (Nomura, 1986a, b) and in the Yamato Basin are essentially coeval responses to this paleoceanographic change, which was a function of the uplift of the Backbone Range.

The appearance of an agglutinated fauna in the Spirosigmoilinella compressa/Martinottiella communis Zone at Site 794 correlates well with the appearance of the FSL in Northeast Honshu at the N9/10 boundary (Maiya, 1978). The dissolved oxygen content in bottom water largely determines the nature of the benthic fauna (Thompson et al., 1985); thus, the second barren interval likely reflects limited content of dissolved oxygen in bottom water. Critical oxygen content for the presence of a calcareous fauna is about $0.3 \mathrm{~mL} / \mathrm{L}$ (Thompson et al., 1985). Oxygen supply into bottom water may also be regulated by local topographic features.

The idea of middle Miocene development of agglutinated foraminifers along the northern Sea of Japan coast as a function of the uplift of the Backbone Range of Northeast Honshu was originally proposed by Asano et al. (1969) and Maiya (1988). Specifically, Maiya (1988) suggests that faunal differentiation between the Sea of Japan and the Pacific sides occurred at N9 (15 Ma) due to lifting of the backbone range and the prevalence of cold-water species. This age is also coincident with the presumed vertical and horizontal movement of Southwest Honshu. On the basis of the rotation event of the Honshu arc ( 15 Ma), Chinzei (1986) considered that the molluscan faunal change from warm- to cold-water taxa was caused by the closing of the Korea and Tsushima straits and by intrusion of northern cold water. A similar model has been applied to the benthic foraminiferal faunal change by Ujiie (1988), though he supposes that the Pacific water flow came through Central Honshu. However, the deep-water stagnation in the Sea of Japan cannot be explained solely by the closing of the above straits. Although I cannot identify particular straits for the Pacific deep-water inflow to the Sea of Japan, I assume that there were many channels prior to uplift of the Backbone Ranges.

The Second Foraminiferal Sharp Line, however, appears at 11.2 $\mathrm{Ma}$ at Site 795 in the Japan Basin. According to Maiya and Inoue (1981), the disappearance of warm-water planktonic foraminifers (a Planktonic Foram Sharp Surface defined by these latter authors) is stratigraphically very distinct and marks the introduction of coldwater planktonic foraminifers (the Globorotalia pseudopachyderma/Globigerina woodi Zone of Maiya (1978)) in the Sea of Japan. It is likely that cold deep water replaces the previous deep water at this time as marked by agglutinated foraminifers. Nevertheless, benthic foraminifers in the $O$. umbonatus $C$. wuellerstorfi Zone at Site 795 indicate great similarity to those of the $C$. wuellerstorfi and the $G$. orbicularis/G. planulatus zones at Site 797 (Fig. 21). Increasingly oxic bottom water apparently began to form from about $11.6 \mathrm{Ma}$ at Site 797. This age is surprisingly close to the appearance of the second FSL at Site 795 and suggests that the second FSL at Site 795 was not formed through the opening event of the Sea of Japan as in the case of the first FSL but rather may be related to a large-scale water mass change in the North Pacific Ocean. Woodruff (1985) suggested stepwise paleoceanographic changes in the Pacific Ocean during the Miocene. The changes are correlated with cooling of the deep Pacific Ocean due to Antarctic glacial expansion and are expressed by the clear isotopic changes at $14.5 \mathrm{Ma}$ and 8-10 Ma. During these periods, benthic foraminifers change their distribution patterns in addition to origination and extinction of species. In particular, the late Miocene paleoceanographic event is related to the intensification of organic productivity by thermohaline circulation, which resulted in the development of low-oxygen deep water and an increase of deep-sea dissolution of calcareous matter. Although the timing of the Second FSL is not exactly the same as that of the latter paleoceanographic change, 


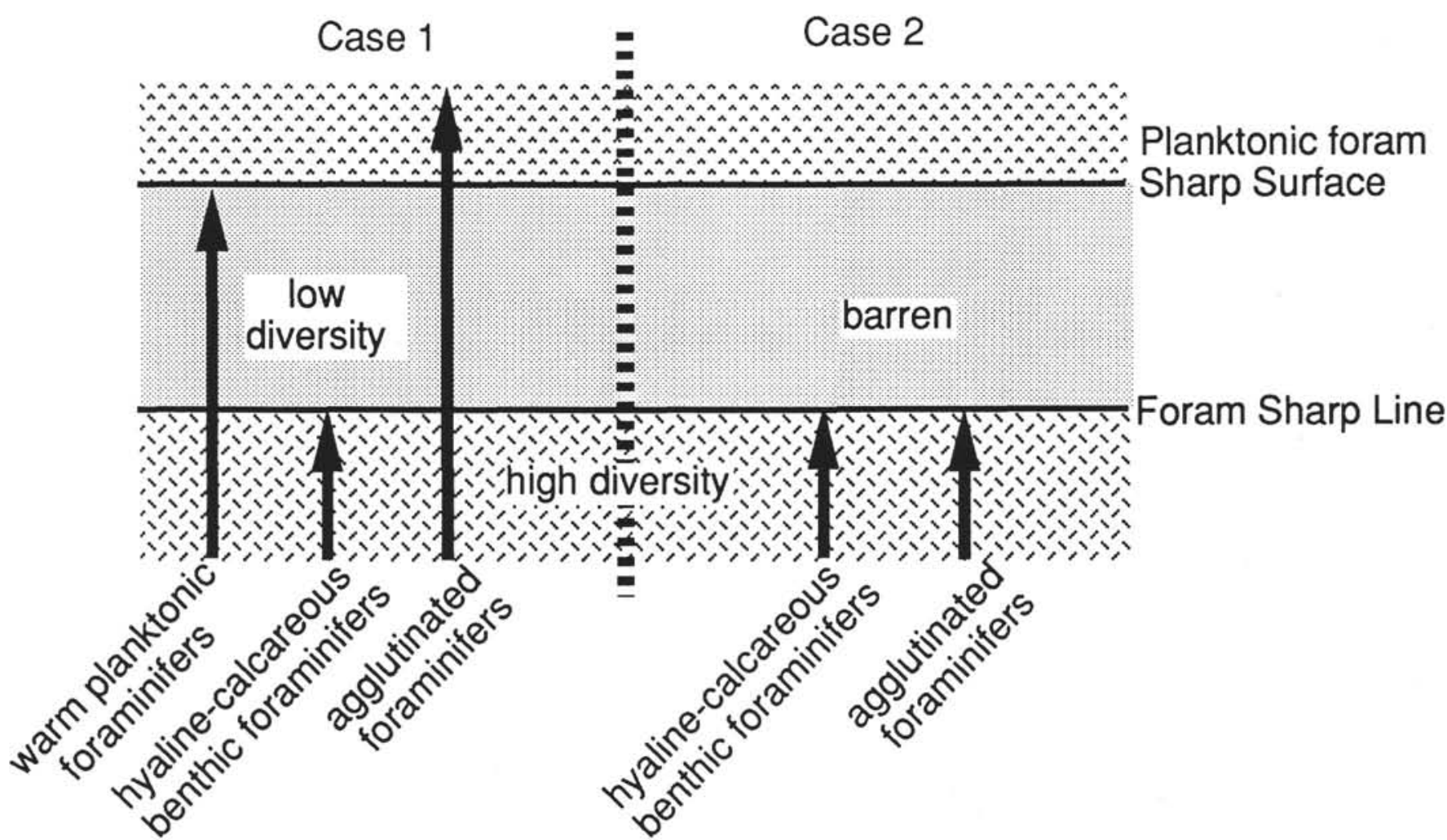

Figure 18. Conceptual diagram of the Foram Sharp Line (Tai, 1963) and the Planktonic Foram Sharp Surface (Maiya and Inoue, 1981). The Foram Sharp Line (FSL) is recognized as the stratigraphic horizon that changes from the high-diversity benthic fauna containing both hyaline-calcareous and agglutinated foraminifers to the low-diversity fauna consisting of agglutinated foraminifers (case 1) or barren interval (case 2). Both cases are defined as occurring in middle Miocene mudstone sequences. The Planktonic Foram Sharp Surface is the stratigraphic horizon characterized by the disappearance of warm planktonic foraminifers from the Sea of Japan borderland regions.

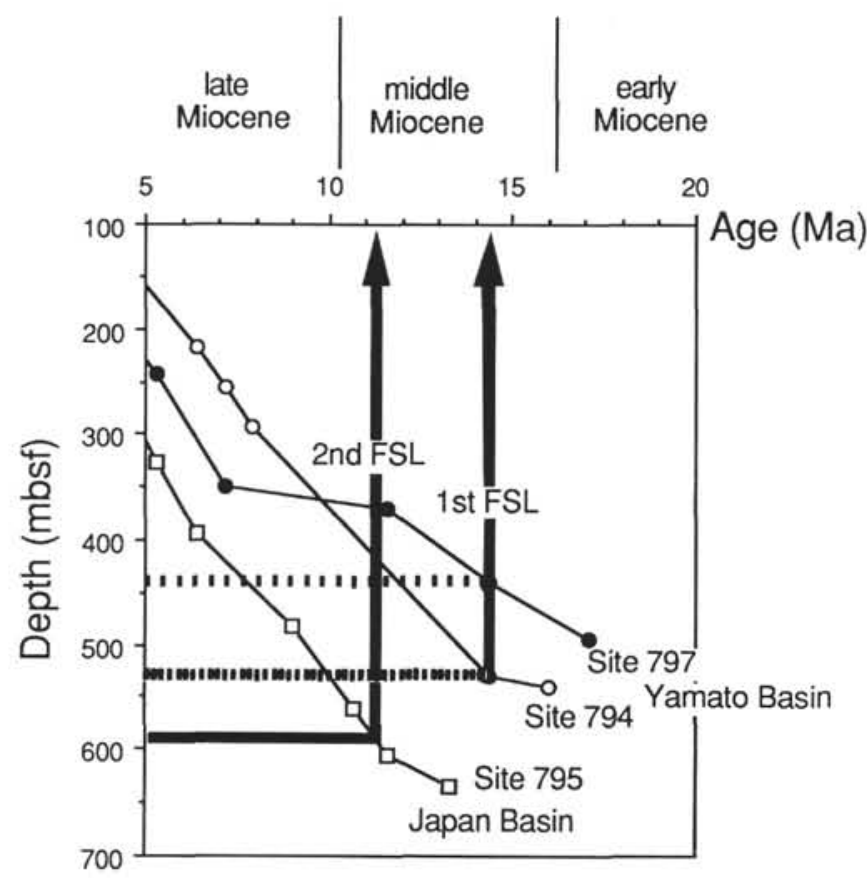

Figure 19. Age distribution of the Foram Sharp Lines (FSL) with respect to variations in rate of sediment accumulation. The First FSL appears at the 14-15 Ma interval at Sites 794 and 797. The Second FSL appears at 11.2 Ma at Site 795. intensified thermohaline circulation with the development of North Atlantic Deep Water becomes more active at approximately $11 \mathrm{Ma}$ (Woodruff and Savin, 1989). Northward movement of nutrient-rich intermediate water likely activated primary production through upwelling in the North Pacific Ocean. This global change of ocean bottom water may also be responsible for the increase of agglutinated foraminifers in marginal seas. After the late middle Miocene, lithological units represented by diatomaceous ooze and claystone prevailed at both Sites 795 and 797 , which suggests that the active upwelling in the Sea of Japan begins from this time.

\section{Opening of the Sea of Japan: Benthic Foraminiferal Evidence}

The theory for the opening of the Sea of Japan proposed by Otofuji and Matsuda $(1983,1984)$ and Otofuji et al. (1985a, c) calls for the Southwest Honshu arc to rotate clockwise to its present position at about 14-15 Ma. Counter-clockwise opening of the Northeast Honshu arc occurred at about 15-20 Ma (Hamano and Tosha, 1985) and at 11-21 Ma (Otofuji et al., 1985b, 1986). Coincident subsidence based on the benthic foraminiferal data discussed earlier supports a major geologic event at $\sim 15 \mathrm{Ma}$. Subsidence suggests that a compressional stress field may have been present in the Japanese Islands among this time. Prior to N9 (about $16 \mathrm{Ma}$ ), however, there is no evidence of the compressional stress in Southwest Honshu based on benthic foraminiferal evidence. Distribution patterns of volcanic dikes support the idea that the Sea of Japan side of Southwest Honshu was positioned in the tensional stress field before $15 \mathrm{Ma}$ (Tsunakawa and Takeuchi, 


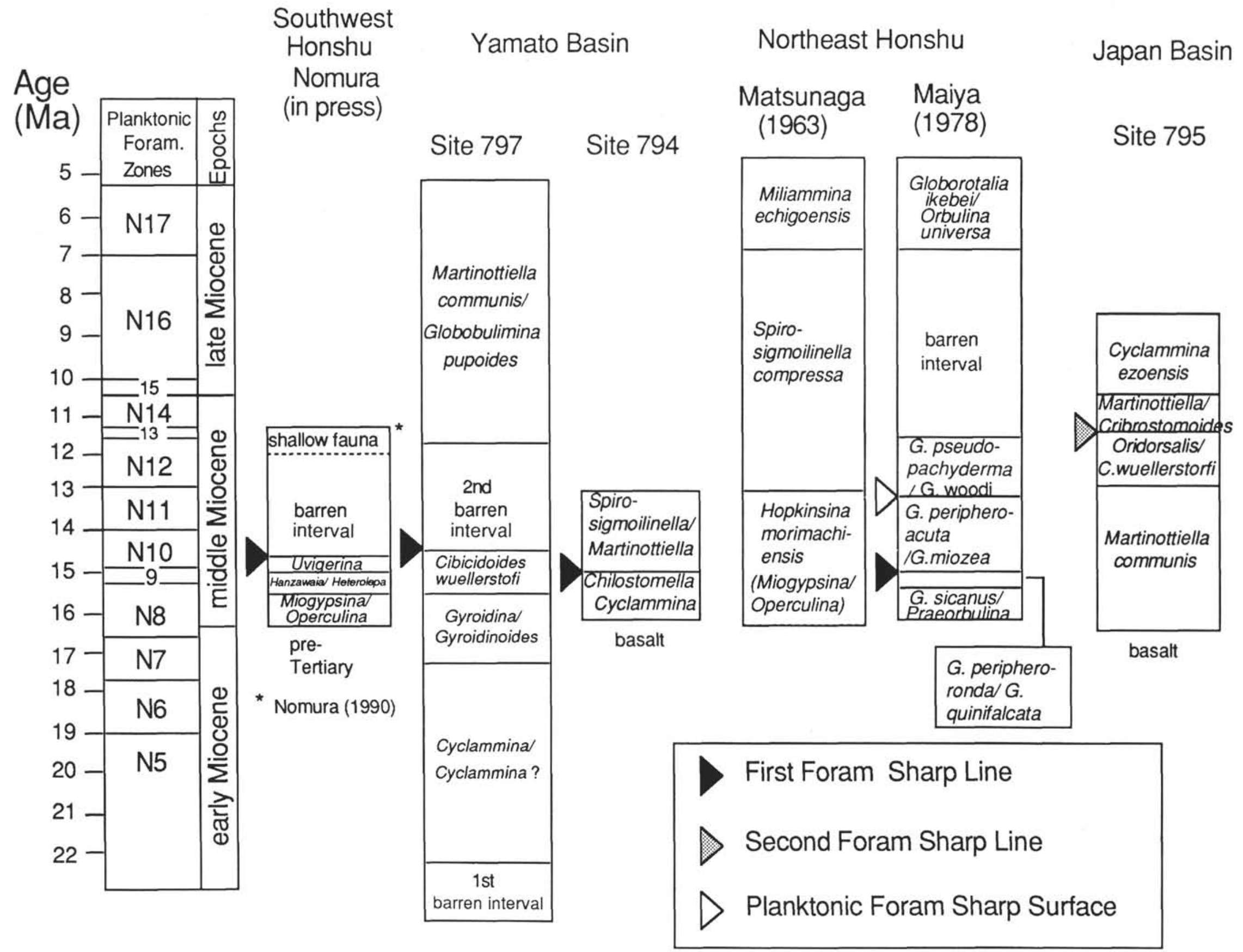

Figure 20. Correlation of benthic foraminiferal zones from Sites 794 795, and 797 with zones of Southwest Honshu (Nomura, in press) and Northeast Honshu (Matsunaga, 1963) and correlation with the planktonic foraminiferal zones of Maiya (1978). 


\section{Dice's similarity coefficients}

$-0.020 .07^{0.16} 0.25^{0.34} 0.42^{0.51} 0.600^{0.69} 0.78^{0.86} 0.95^{1.04}$ Samples

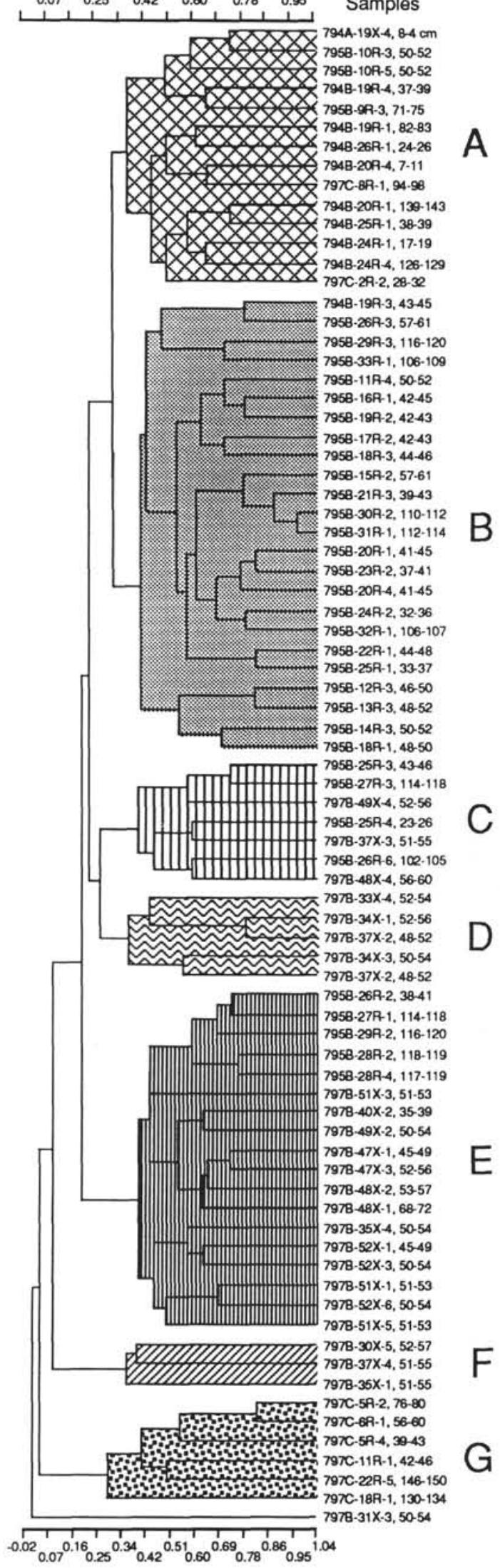

Figure 21. Cluster analysis at Sites 794, 795, and 797.
1983). In general, gradual deepening occurs in Southwest Honshu in association with a global marine transgression, which suggests that the Honshu arc was in a tensional stress field during this epoch (N8). After initial rifting, the Sea of Japan was positioned in the tensional stress field during the Miocene (Tamaki, 1985, 1988). In contrast to the movement of the Japanese Islands, the Sea of Japan sites show only gradual deepening of the oceanic basin during the Miocene, without signs of uplifting during N9. In order to explain the change of the stress field deduced from benthic faunal change, two opening processes proposed by Hayashida and Torii (1988) and Hayashida et al. (1991) may be more reasonable than a simple rotation of the Japanese Islands. The Japanese Islands moved southwardly in the first opening event at about 15-16 $\mathrm{Ma}$ and subsequently rotated to their present position during a short interval at about $15 \mathrm{Ma}$. This geophysical process fits the spreading model of Tamaki $(1985,1988)$. The timing of the separation of Japan from Asia is thought to have begun at about $16 \mathrm{Ma}$ because the N8 Miocene marine transgression is widely recognized in various areas in the Japanese Islands, and no pre-N8 marine fossils have been recorded in the Sea of Japan borderland. Japanese paleontologists commonly believe that the presence of nonmarine or brackish sedimentary basins formed in the Sea of Japan area before the marine transgression (Koizumi, 1988). However, evidence from Site 797 clearly suggests that the Yamato Basin reached bathyal depths in the late early Miocene.

In order to explain such developmental processes of the Sea of Japan, a model derived from benthic foraminiferal changes is indicated in Figure 23. As shown in the zone boundary from the Cyclammina sp. A/Cyclammina? sp. Zone to the Gyroidina/Gyroidinoides Zone, a distinct faunal change occurred at $17.1 \mathrm{Ma}$. This zone boundary at $17.1 \mathrm{Ma}$ is thought to indicate a change in oxygen content from low to high. After 17.1 Ma, calcareous foraminifers are abundant and suggest that the favorable ocean circulation developed in the Sea of Japan. Oxygen supply to bottom water should have been promoted by new water inflow into the Sea of Japan owing to the enlargement of the Sea of Japan. This interpretation indicates that the first opening of the Sea of Japan must have commenced at 17.1 Ma or earlier. Thus, the opening of the Sea of Japan occurred at least 1 m.y. earlier than previously thought (Hayashida et al., 1991; Chiji et al., 1989). The early Miocene Proto-Japan Sea may have been narrow, deep depressions with poor deep-water circulation, as interpreted by Tamaki, Pisciotto, Allan, et al. (1990).

The second phase in the opening of the Sea of Japan is related to the differential vertical movement of the Japanese Islands as previously mentioned. Toward the end of the initial opening, the first FSL marked the typically anoxic back-arc basins phase with oxygendeficient bottom water. This paleoceanographic event was restricted to the Yamato Basin. Oxygenated deep water entered into the Japan Basin at about $13 \mathrm{Ma}$ and continued up to about $11 \mathrm{Ma}$, as indicated by the fauna of the $O$. umbonatus/C. wuellerstorfi Zone, an age which may be related to the opening of the northern Yamato Basin. Although the Northeast Honshu arc is known to have gradually opened counterclockwise during 21-11 Ma (Hamano and Tosha, 1985; Otofuji et al., 1985b, 1986), further movement of Hokkaido and other small areas in the northern islands may have affected this faunal change.

\section{CONCLUSIONS}

1. Miocene benthic foraminifers from Sites 794 and 797 (Yamato Basin) and Site 795 (Japan Basin) were quantitatively analyzed. Two assemblage zones were identified at Site 794. Four assemblage zones and two barren intervals were identified at Site 797, and four assemblage zones at Site 795. The Miocene foraminifers from these sites are characterized by deep-water species, suggesting lower bathyal to upper abyssal depths. Major variations in the relative abundances of calcareous and agglutinated foraminifer are also recognized. 
2. The Foram Sharp Line (FSL) is recognized at about $14.3 \mathrm{Ma}$ at Site 797 and $14.4 \mathrm{Ma}$ at Site 794, whereas the FSL at Site 795 is 11.2 Ma. The FSL at about 14.5 Ma is similar to the position of the FSL defined in onshore sequences of the Honshu arc and forms a useful stratigraphic criterion for correlating the Miocene strata. However, the FSL at Site 795 appears about 3 m.y. later and suggests that two FSL's occurred in the Miocene, the first FSL at about 14.5 Ma and the second at about $11.2 \mathrm{Ma}$.

3. The first FSL is related to the opening event of the Sea of Japan. Uplift of the backbone ranges of Honshu at about 15 Ma resulted in the formation of oxygen-deficient deep water in the back-arc basin as well as the inland area of Honshu by confining the inflow of the Pacific deep water. Subsidence indicates a compressional stress field in the Honshu arc and supports the ideas of a clockwise rotation of Southwest Honshu and a counter-clockwise rotation of Northeast Honshu.

4. Calcareous foraminifers become abundant at about $17.1 \mathrm{Ma}$ at Site 797 , which is the boundary between the Cyclammina sp. A/Cyclammina? sp. Zone and the Gyroidina orbicularis/Gyroidinoides planulatus Zone. This faunal change suggests that the bottom water of the Proto-Japan Sea changed from relatively oxygen poor to oxygen rich and geologically suggests the entrance of the oxygen-rich Pacific deep water by enlarging the Proto-Japan Sea. These late early Miocene deep-water faunas indicate that initial rifting and subsidence occurred at least $1 \mathrm{~m} . \mathrm{y}$. earlier than previously considered.

5. The second FSL may be related to a global paleoceanographic change caused by a deep-water cooling and the intensification of thermohaline circulation. Development of intermediate water from development of NADW occurred at about $11 \mathrm{Ma}$ (Woodruff and Savin, 1989). This activated an upwelling and increased the organic productivity in the northern Pacific Ocean, which leads to a solution of calcareous foraminifers in deep sea. Diatom-rich sediments become more common above the second FSL.

6. At Site 795, calcareous foraminifers become common at about 13.3 Ma, which suggests that oxygenated deep water entered the Japan Basin while stagnant bottom water formed at Site 797. Therefore, the northernmost Japan Basin may have independently widened at about $13 \mathrm{Ma}$. This latter event suggests a complex topographic movement in the Sea of Japan during the Miocene time.

\section{ACKNOWLEDGMENTS}

I am very grateful to the shipboard party of Leg 127 for the time they devoted to sampling for this study. I thank Kensaku Tamaki for his kind invitation to study Miocene benthic foraminifers from Leg 127 cores. I prepared part of this study during a visit in Mexico, and I thank Adolfo Molina-Cruz for his courtesy during this period. I thank James Ingle and Martin Lagoe for critically reading the manuscript and for providing helpful suggestions.

\section{REFERENCES}

Asano, K., Ingle, J. C., Jr., and Takayanagi, Y., 1969. Neogene planktonic foraminiferal sequence in northern Honshu. In Brönniman, R. P., and Renz, H. (Eds.), Proc. 1st Int. Conf. Planktonic Microfossils. Leiden (E. J. Brill), $1: 14-25$.

Berggren, W. A., and Miller, K. G., 1989. Cenozoic bathyal and abyssal calcareous benthic foraminiferal zonations. Micropaleontology, 35:308320.

Boltovskoy, E., 1984. Oligocene through Quaternary bathyal foraminifera of worldwide distribution. In Oertli, H. J. (Ed.), Benthos '83: Proc. 2 nd Int. Conf. Benthic Foraminifera: Pau (Elf Aquitaine, Esso REP and Total CFP), $81-85$.

, 1987. Tertiary benthic foraminifera in bathyal deposits of the Quaternary world ocean. J. Foram. Res., 17:279-285.

Chiji, M., 1961. Neogene biostratigraphy of the Toyama sedimentary basin, Japan Sea coast. Osaka Mus. Nat. History, Bull., 14:1-88.
Chiji, M., and IGCP-246 National Working Group of Japan, 1989. Paleogeography and paleoenvironments during the opening of the Sea of Japan. In Chiji, M. (Ed.), Opening of the Sea of Japan and related Neogene events. IGCP-246 National Working Group, Kyoto, and IGCP-246 Pacific Neogene Events in Time and Space: Shizuoka, 57-63.

Chinzei, K., 1986. Faunal succession and geographic distribution of Neogene molluscan faunas in Japan. In Kotaka, T. (Ed.), Japanese Cenozoic molluscs: their origin and migration. Palaeont. Soc. Jpn., Spec. Paper, 29:1732.

Guber, A. L., and Ohmoto, H., 1978. Deep sea environment of Kuroko formation as indicated by the benthic foraminifera from the Hokuroku district, Japan. Mining Geol., 28:245-255.

Hamano, Y., and Tosha, T., 1985. Movement of the northeastem Japan and paleomagnetism. Kagaku (Science), Tokyo (Iwanami Shoten): 55:476483.

Hayashida, A., and Torii, M., 1988. Opening of southwestern part of the Sea of Japan: an attempt for paleoreconstruction. Kaiyoukagaku (Marine Science Monthly), 221:685-689.

Hayashida, A., Fukui, T., and Torii, M., 1991. Paleomagnetism of the early Miocene Kani Group in Southwest Japan and its implication for the opening of the Japan Sea. Geophysical Res. Letters, 18:1095-1098.

Inoue, Y., 1980. Stratigraphic and paleoenvironmental considerations of Holocene to uppermost Pleistocene foraminifera in Nishi-Tsugaru Basin, Sea of Japan. In Igo, H., and Noda, H. (Eds.), Prof. Saburo Kanno Mem. Vol. Tsukuba, 241-261.

Kitazato, H., 1979. Marine paleobathymetry and paleotopography of the Hokuroku district during the time of the Kuroko deposition, based on foraminiferal assemblages. Mining Geol, 29:207-216.

Koizumi, I., 1988. Early Miocene Proto-Japan Sea. J. Paleont. Soc. Korea, 4:6-20.

Maiya, S., 1978. Late Cenozoic planktonic foraminiferal biostratigraphy of the oil-field region of Northeast Japan. In Fujita, K., Ichikawa, K., Ichihara, M., Chiji, M., Unabara, K., Fujita, T., and Takayanagi, Y. (Eds.), Cenozoic Geology of Japan (Prof. N. Ikebe Mem. Vol.). Osaka, 35-60.

, 1988. Neogene events as revealed by changes of foraminiferal assemblages from central and northern Japan. In Tsuchi, R. (Ed.), Neogene biotic evolution and related events. Osaka Mus. Nat. Hist., Spec. Publ., $31-48$.

Maiya, S., and Inoue, Y., 1981. Historical changes of lower middle Miocene foraminiferal assemblages and paleogeography in Niigata Basin. Kaseki (Fossils), 30, 73-78.

Matoba, Y., 1981. The Sea of Japan at the time around Middle Miocene inferred from foraminiferal evidence. Kaseki (Fossils), 30:78-85.

-1983 . A discussion on the estimations of the depth in the Hokuroku district during the time of the Kuroko deposition. Mining Geol., Spec.Issue, 11:251-26i.

, 1984. Paleoenvironment of the Sea of Japan. In Oertli, H. J. (Ed.), Benthos '83:Proc. 2nd Int. Conf. Benthic Foraminifera: Pau (Elf Aquitaine, Esso REP and Total CFP), 409-414.

Matoba, Y., and Honma, N., 1986. Depth distribution of Recent benthic foraminifera off Nishitsugaru, eastern Sea of Japan. In Matoba, Y., and Kato, M. (Eds.), Studies on Cenozoic Benthic Foraminifera in Japan: Akita, 53-78.

Matsunaga, T., 1963. Benthic smaller foraminifera from the oil fields of Northern Japan. Tohoku Univ. Science Repts, 2nd ser.(Geol.), 35, 67-122.

Morkhoven, F.P.C.M. van, Berggren, W. A., and Edward, A. S., 1986. Cenozoic cosmopolitan deep-water benthic foraminifera. Bull. Centres Rech. Exploration-Production Elf Aquitaine, Mem. 11,: Pau, France.

Nomura, R., 1986a. Geology of the central part in the Shimane Peninsula: Part 1: Miocene stratigraphy. J. Geol. Soc. Jpn., 92, 405-420.

$-1986 \mathrm{~b}$. Geology of the central part in the Shimane Peninsula: Part 2: Biostratigraphy and paleoenvironment viewed from benthic foraminifera. J. Geol. Soc. Jpn., 92, 461-475.

, 1989. On the Foram. Sharp Line in the Bihoku Group. Studies of the San' in Region (Nat. Environ.), 5:35-44.

, 1990. Late middle Miocene foraminifera from the Matsue Formation, Shimane Prefecture. Trans. Proc. Palaeont. Soc. Japan, N. S., 158:459-484.

- , in press. Miocene benthic foraminifera from the Bihoku Group: the geologic age of the Foram. Sharp Line and the relation to the opening of the Sea of Japan. J. Geol. Soc. Jpn., 98.

Otofuji, Y., and Matsuda, T., 1983. Paleomagnetic evidence for the clockwise rotation of Southwest Japan. Earth Planet. Sci. Lett., 62, 349-359. 
1984. Timing of rotational motion of Southwest Japan inferred from paleomagnetism. Earth Planet. Sci. Lett., 70, 373-382.

Otofuji, Y., Matsuda, T., and Nohda, S., 1985a, Opening mode of the Japan Sea inferred from the paleomagnetism of the Japan Arc. Nature, 317:603604.

1985b. Paleomagnetic evidence for the Miocene counter-clockwise rotation of Northeast Japan: rifting process of the Japan arc. Earth Planet. Sci. Lett., 75:265-277.

Otofuji, Y., Hayashida, A., and Torii, M., 1985c. When was the Japan Sea opened?: Paleomagnetic evidence for Southwest Japan. In Nasu, N., Uyeda, S., Kushiro, I., Kobayashi, K., and Kagami, H., (Eds.), Formation of Active Ocean Margins: Tokyo (Terrapub.), 551-566.

Otofuji, Y., Matsuda, T., and Nohda, S., 1986. Brief review of Miocene opening of the Japan Sea: Paleomagnetic evidence from the Japan arc. J. Geomag. Geoelectr., 38:287-294.

Peterson, L., and Backman, J., 1990. Late Cenozoic carbonate accumulation and the hisory of the carbonate compensation depth in the western equatorial Indian Ocean. In Duncan, R. A., Backman, J., and Peterson, L. C., et al., Proc. ODP, Sci. Results, 115: College Station, TX (Ocean Drilling Program), 467-507.

Serova, M. Ya., and Tai, Y., 1977. Development phases of foraminifers and correlation of Neogene sections of Kamchatka and Japan. Vopr. Mikropaleontol., 20:127-180.

Tai, Y., 1959. Miocene microbiostratigraphy of West Honshu, Japan. Hiroshima Univ., J. Sci., ser. C, 2:265-395.

,1963. Historical change of the Neogene foraminiferal assemblages in the Setouchi and San-in provinces and Foram. Sharp Line. Kaseki (Fossils), 5:1-7.

, 1985. On so-called Foram. Sharp Line. Hiroshima Univ., Fac. Integrated Arts and Sci., Mem., ser. IV, 10:17-33.

, 1988. Foraminiferal Sharp Line and its microbiostratigraphic significance. Mukogawa Women's Univ., Edu. Bull., 35:87-103.

Tamaki, K., 1985. Two models of back-arc spreading. Geology, 13:475-478.

1988. Geological structure of the Japan Sea and its tectonic implications. Geol. Surv. Jpn. Bull., 39:269-365.

Tamaki, K., Pisciotto, K., Allan, J., et al., 1990. Proc. ODP, Init. Repts., 127 College Station, TX (Ocean Drilling Program).

Thomas, E., and Vincent, E., 1987. Equatorial Pacific deep-sea benthic foraminifera: faunal changes before the middle Miocene polar cooling. Geology, 15:1035-1039.

Thompson, J. B., Mullins, H. T., Newton, C. R., and Vercoutere, T. L., 1985. Alternative biofacies model for dysaerobic communities. Lethaia, 18:167179.

Thompson, P. R., 1980. Foraminifers from Deep-Sea Project Sites 434, 435 , and 436, Japan Trench. In von Huene, R., and Nasu, N., et al., Init. Repts. DSDP, 56, 57: Washington (U.S. Govt. Printing Office), 775-807.

Tsunakawa H., and Takeuchi, A., 1983. Paleo-stress fields of the Japanese Islands and volcanic activity. Kagaku (Science), Tokyo (Iwanami Shoten), 53:624-631

Ujiie, H., 1988. Benthic foraminiferal changes related to tectonic development of the Sea of Japan. Revue de Paleobiol., Spec. Vol. 2 (Benthos '86), 895-901.

Ujiie, H., and Ichikura, M., 1973. Holocene to uppermost Pleistocene planktonic foraminifera in a piston core from the San'in District, Sea of Japan. Trans. Proc. Palaeont. Soc. Jpn., 91:137-150.

Ujiie, H., Ichikura, M., and Kurihara, K., 1983. Quaternary benthonic foraminiferal changes observed in the Sea of Japan piston cores. Nat. Sci. Museum, Bull., ser. C (Geol. Paleont.), 9:41-78.

van Andel, T. H., 1975. Mesozoic-Cenozoic calcite compensation depth and the global distribution of calcareous sediments. Earth Planet. Sci. Lett. 26:187-194.

Woodruff, F., 1985. Changes in Miocene deep-sea benthic foraminiferal distribution in the Pacific Ocean: relationship to paleoceanography. In Kennett, J. P. (Ed.), The Miocene Ocean: Paleoceanography and Biogeography. Geol. Soc. Am. Mem., 163:131-176.

Woodruff, F., and Savin, S. M., 1989. Miocene deep water oceanography. Paleoceanography, 4:87-140.

\section{Date of initial receipt: 27 March 1991 \\ Date of acceptance: 23 September 1991 \\ Ms 127/128B-187}

\section{SPECIES REFERENCE LIST}

All of the species and genera identified in this study are listed below.

Ammodiscus concinnus V. Kuznetzova, 1970.

Ammodiscus macilentus Chapman $=$ Ammodiscus incertus (d'Orbigny) var. macilenta Chapman, 1904.

Ammodiscus tenuis Brady, 1881.

Ammodiscus spp.

Ammosphaeroidina sp.

Ammovertellina sp.

Astrononion spp.

Bathysiphon spp.

Bermudezina aminaensis Bermudez, 1949.

Brizalina spp.

Buccella $\mathrm{cf}$. kuromatsunaiensis = cf. Buccella kuromatsunaiensis Shirai, 1960.

Bulimina rostrata Brady, 1884

Bulimina striata d'Orbigny, 1826.

Bulimina spp.

Chilostomella oolina Schwager, 1878.

Cibicides $\mathrm{cf}$. refulgens Montfort = cf. Cibicides refulgens Montfort, 1808.

Cibicides sp.

Cibicidoides bradyi $($ Trauth $)=$ Truncatulina bradyi Trauth, 1918 .

Cibicidoides wuellerstrofi $($ Schwager) $=$ Anomalina wuellerstorfi Schwager, 1866.

Cibicidoides spp.

Cribrostomoides cf. crassimargo $($ Norman $)=$ cf. Haplophragmium crassimargo Norman, 1892.

Cribrostomoides spp.

Cyclammina cancellata Brady, 1881.

Cyclammina ezoensis Asano, 1951.

Cyclammina cf. japonica Asano, 1950.

Cyclammina orbicularis Brady, 1881

Cyclammina pusilla Brady, 1881

Cyclammina spp.

Dentalina insecta $($ Schwager $)=$ Nodosaria insecta Schwager, 1866 .

Dentalina spp.

Discammina compressa $($ Goës $)=$ Lituolina irregularis var. compressa Goës, 1882.

Eggerella bradyi $($ Cushman $)=$ Verneuilinella bradyi Cushman, 1911 .

Eggerella sp.

Elphidium bartletti Cushman $=$ Elphidium bartletti Cushman, 1933.

Elphidium cf. jenseni $($ Cushman $)=$ cf. Polystomella jenseni Cushman, 1924. Elphidium cf. perforatum Nomura = cf. Elphidium perforatum Nomura, 1990. Elphidium subarcticum Cushman, 1944.

Elphidium spp.

Epistominella sp.

Evolvocassidulina kawanoi $($ Matoba) $=$ Cassidulinoides kuwanoi Matoba, 1967.

Fissurina spp.

Fissurina marginata $($ Montagu $)=$ Vermiculum marginatum Montagu, 1803.

Fissurina orbignyana Seguenza, 1862.

Fursenkoina ishikiensis $($ Asano $)=$ Virgulina ishikiensis Asano, 1949.

Fursenkoina spp.

Gaudryinella sp.

Gavelinopsis sp.

Glabratella subopercularis (Asano) = Discorbis subopercularis Asano, 1951.

Glandulina $\mathrm{cf}$. nipponica $=\mathrm{cf}$. Glandulina nipponica Asano, 1951.

Globobulimina perversa $($ Cushman $)=$ Bulimina pyrula d'Orbigny var. perversa Cushman, 1921.

Globobulimina pupoides (d'Orbigny) = Bulimina pupoides d'Orbigny, 1846 . Globobulimina spp.

Globocassidulina globosa $($ Hantken $)=$ Cassidulina globosa Hantken, 1875. Globocassidulina spp.

Glomospira sp.

Gyroidina orbicularis d'Orbigny, 1826.

Gyroidinoides planulatus $($ Cushman and Renz $)=$ Gyroidina planulatus Cushman and Renz, 1941.

Haplophragmoides spp.

Hippocrepinella variabilis Voloshinova, 1970. 


\section{R. NOMURA}

Hopkinsina sp.

Hormosina spp.

Islandiella $\mathrm{cf}$. compressa Nomura = cf. Islandiella compressa Nomura, 1983.

Islandiella helenae Feyling-Hanssen and Buzas, 1976.

Islandiella $\mathrm{sp}$.

Lagena cf. apiopleura Loeblich and Tappan = cf. Lagena apiopleura Loeblich and Tappan, 1953.

Lenticulina spp.

Lituotuba sp.

Marginulina cf. glabra d'Orbigny = cf. Marginulina glabra d'Orbigny, 1826 .

Marginulina sp.

Martinottiella communis (d'Orbigny) = Clavulina communis d'Orbigny, 1826 .

Melonis nikobarense $($ Cushman $)=$ Nonion nikobarensis Cushman, 1936.

Melonis pompilioides (Fichtel and Moll) $=$ Nautilus pompilioides Fichtel and Moll, 1798.

Miliolinella sp.

Nodosaria longiscata d'Orbigny, 1846.

Nodosaria spp.

Nonionellina labradorica (Dawson) $=$ Nonionina labradorica Dawson, 1860.

Nonionella miocenica Cushman, 1927.

Nonionella stella Cushman and Moyer $=$ Nonionella miocenica Cushman var. stella Cushman and Moyer, 1930.

Nonionella spp.

Oolina globosa $($ Montagu $)=$ Vermiculum globosum Montagu, 1803 .

Oolina hexagona (Williamson) = Entosolenia squamosa (Montagu) var. hexagona Williamson, 1848.

Oolina spp.

Oridorsalis umbonatus (Reuss) = Rotalia umbonata Reuss, 1851.

Oridorsalis spp.

Parafissurina sp.

Planodiscorbis sp.

Plectina nipponica Asano, 1951.

Proteonina compressa Cushman and McCulloch, 1919.

Pullenia bulloides (d'Orbigny) = Nonionina bulloides d'Orbigny, 1846 .

Pullenia quinqueloba (Reuss) = Nonionina quinqueloba Reuss, 1851 .

Pullenia salisburyi R. E. and K. C. Stewart, 1930.

Pullenia subcarinata (d'Orbigny) = Nonionina subcarinata d'Orbigny, 1839 .

Pullenia sp.

Pyrgo cf. vespertilio (Schlumberger) $=\mathrm{cf}$. Biloculina vespertilio Schlumberger, 1891.
Pyrgo murrhina $($ Schwager $)=$ Biloculina murrhina Schwager, 1866 .

Pyrgo spp.

Quadrimorphina sp.

Quinqueloculina cf. seminula (Linnaeus) = cf. Serpula seminulum Linnaeus, 1767.

Quinqueloculina vulgaris d'Orbigny, 1826.

Quinqueloculina spp.

Recurvoides? sp.

Reophax excentricus Cushman, 1910.

Reophax spp.

Rhizammina sp.

Saccammina sphaerica Brady, 1881.

Saracenaria sp.

Schizammina sp.

Sphaeroidina cf. compacta Cushman and Todd = cf. Sphaeroidina compacta Cushman and Todd, 1949.

Sphaeroidina japonica Asano, 1953.

Spiroplectammina sp.

Spirosigmoilinella compressa Matsunaga, 1955.

Stilostomella sp.

Technitella sp.

Textularia sp.

Thalmannammina $\mathrm{cf}$. parkerae $($ Uchio) $=\mathrm{cf}$. Recurvoides parkerae Uchio, 1960.

Tosaia hanzawai Takayanagi, 1953.

Trochammina cf. globigeriniformis (Parker and Jones) = Lituola nautiloidea var. globigeriniformis Parker and Jones, 1865.

Trochammina sp.

Trifarina spp.

Triloculina sp.

Uvigerina $\mathrm{cf}$. segundoensis Cushman and Galliher =cf. Uvigerina segundoensis Cushman and Galliher, 1934.

Uvigerina $\mathrm{cf}$. modeloensis Cushman and Kleinpell = Uvigerina modeloensis Cushman and Kleinpell, 1934.

Uvigerina proboscidea Schwager, 1866.

Uvigerina spp.

Valvulineria $\mathrm{cf}$. sadonica Asano = cf. Valvulineria sadonica Asano, 1951.

Valvulineria masudai Asano, 1953.

Valvulineria spp. 


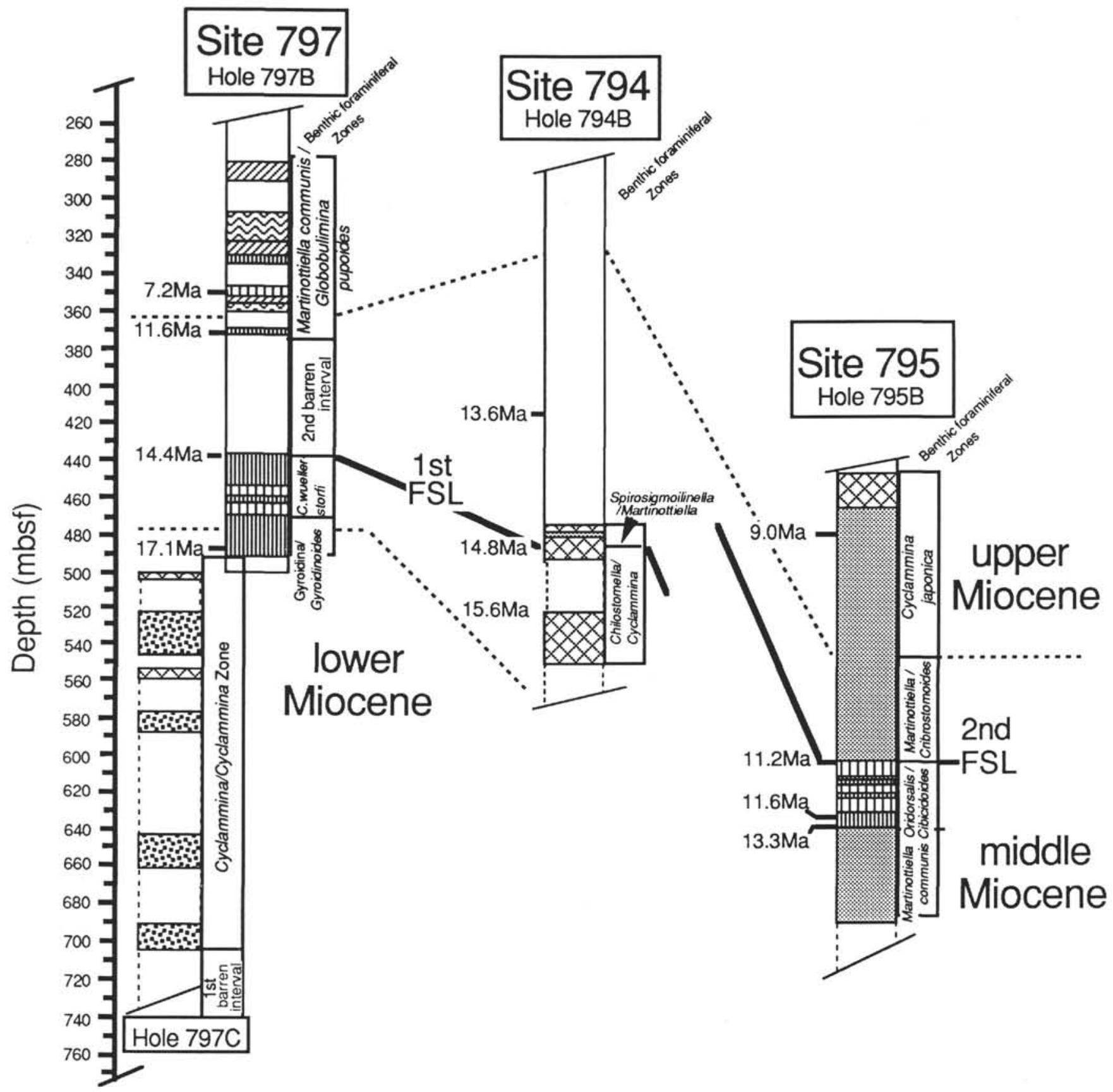

Sample clusters based on Dice's coefficients

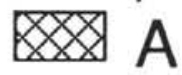

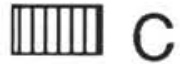

运

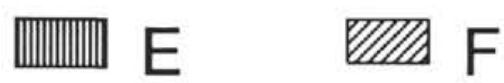

翏 G

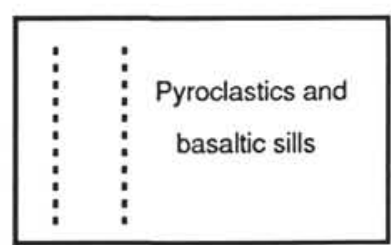

Figure 22. Distribution of sample clusters (A-G) at Sites 794, 795, and 797. 

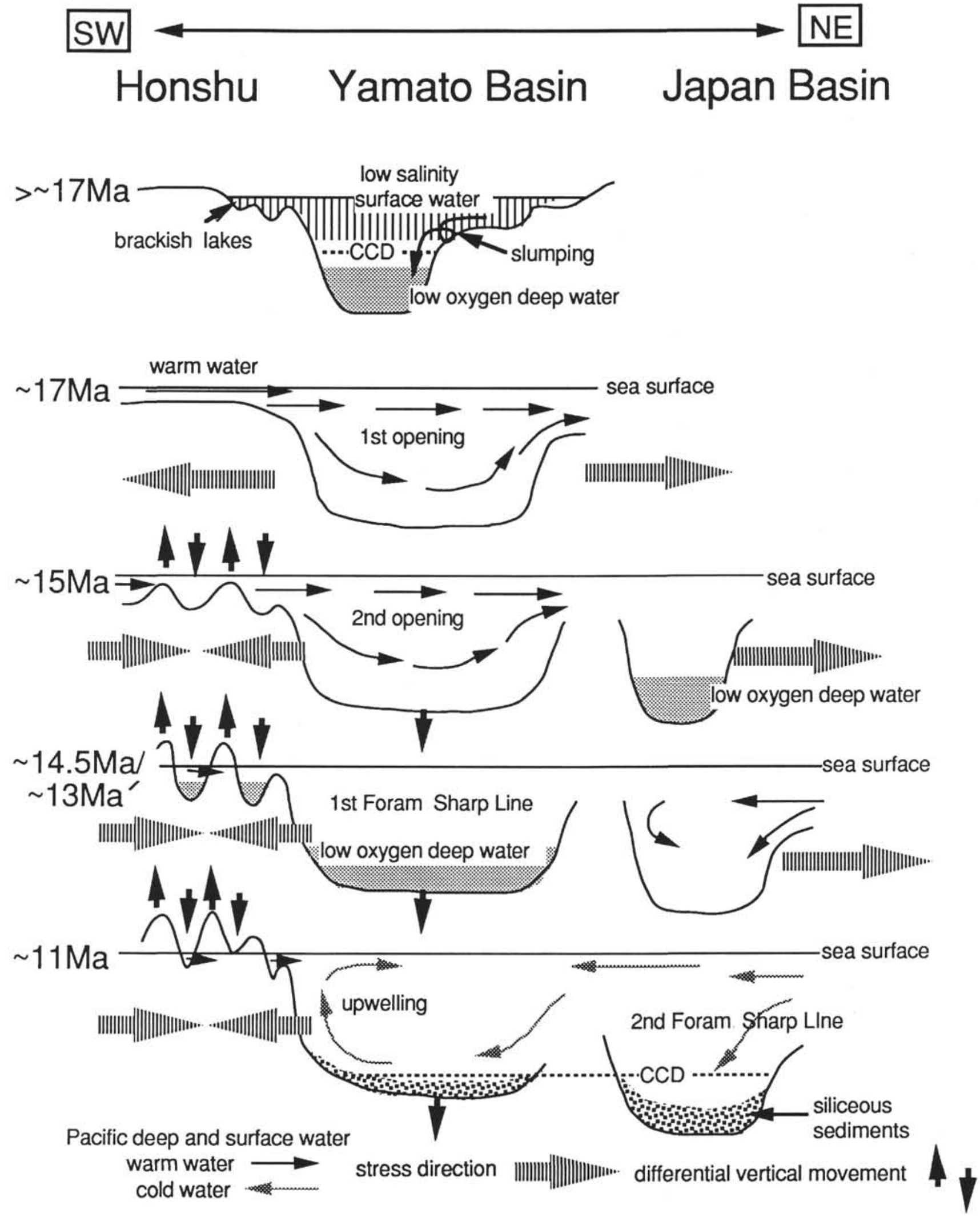

Figure 23. Simplified model of the development of the Japan Sea with reference to geologic events within the Honshu arc (particularly Southwest Honshu). 


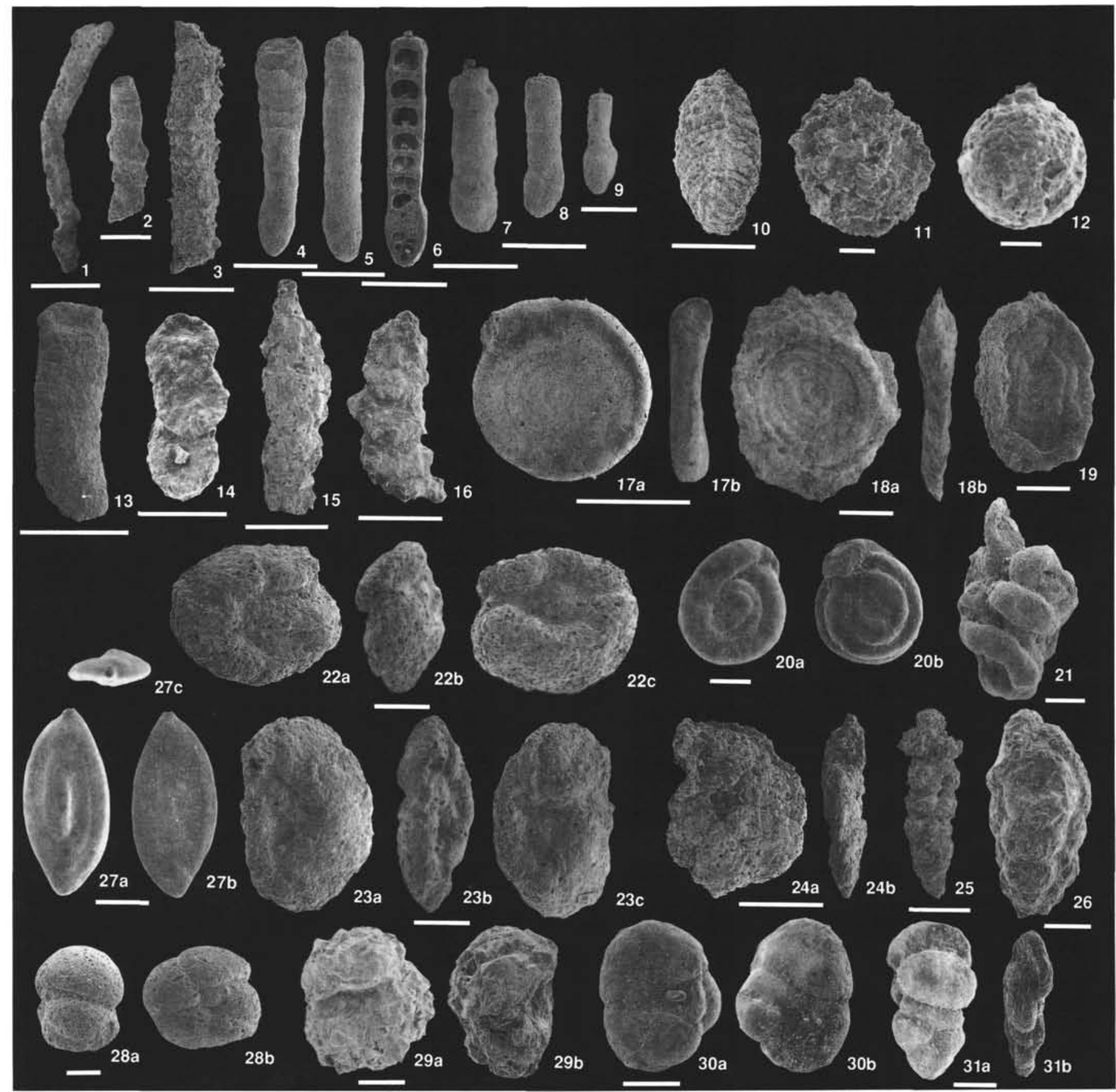

Plate 1. Scale $=100 \mu \mathrm{m}$. 1. Schizammina? sp., 127-795B-18R-1, 48-50 cm. 2. Schizammina? sp., 127-797C-6R-1, 56-60 cm. 3. Rhizammina sp., 127-797C-5R-2, 76-80 cm. 4. Martinottiella communis, 127-795B-19R-2, 42-43 cm. 5. Martinottiella communis, 127-795B-20R-4,41-45 cm. 6. Dissected specimen of Martinottiella communis, 127-795B-22R-1, 44-48 cm. 7. Martinottiella communis, 127-797B-40X-2, 35-39 cm. 8. Martinottiella communis, 127-795B-15R-2, 57-61 cm. 9. Martinottiella communis, 127-795B-24R-6, 17-21 cm. 10. Hippocrepinella variabilis, 127-795B-15R-2, 57-61 cm. 11. Proteonina compressa, 127-795B-18R-3,44-46 cm. 12. Saccammina sphaerica, 127-795B-27R-1,114-118cm. 13. Bathysiphon sp., 127-797B-51X-5,51-53 cm. 14. Plectina nipponica, 127-797B-51X-5,51-53 cm. 15. Reophax sp., 127-795B-18R-1,48-50 cm. 16. Reophax sp., 127-797B-51X-5, 51-53 cm. 17a, b. Ammodiscus tenuis, 127-797C-6R-1, 56-60 cm. 18a, b. Ammodiscus macilentus, 127-795B-10R-5, 50-52 cm. 19. Ammodiscus tenuis, 127-795B-18R-1, 48-50 cm. 20a, b, 21. Ammovertellina sp., 127-797C-2R-2, 28-32 cm. 22a-c, 23a-c. Cribrostomoides cf. crassimargo, 127-795B-18R-1, 48-50 cm. 24a,

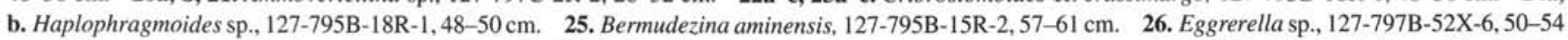
cm. 27a-c. Spirosigmoilinella compressa, 127-795B-18R-3, 44-46 cm. 28a, b. Thalmannammina cf. parkerae, 127-797C-2R-2, 28-32 cm. 29a, b. Trochammina cf. globigeriniformis, 127-795B-10R-3, 50-52 cm. 30a, b. Ammosphaeroidina sp., 127-795B-10R-3, 50-52 cm. 31a, b. Eggerella bradyi, 127-795B-24R-2, 32-36 cm. 


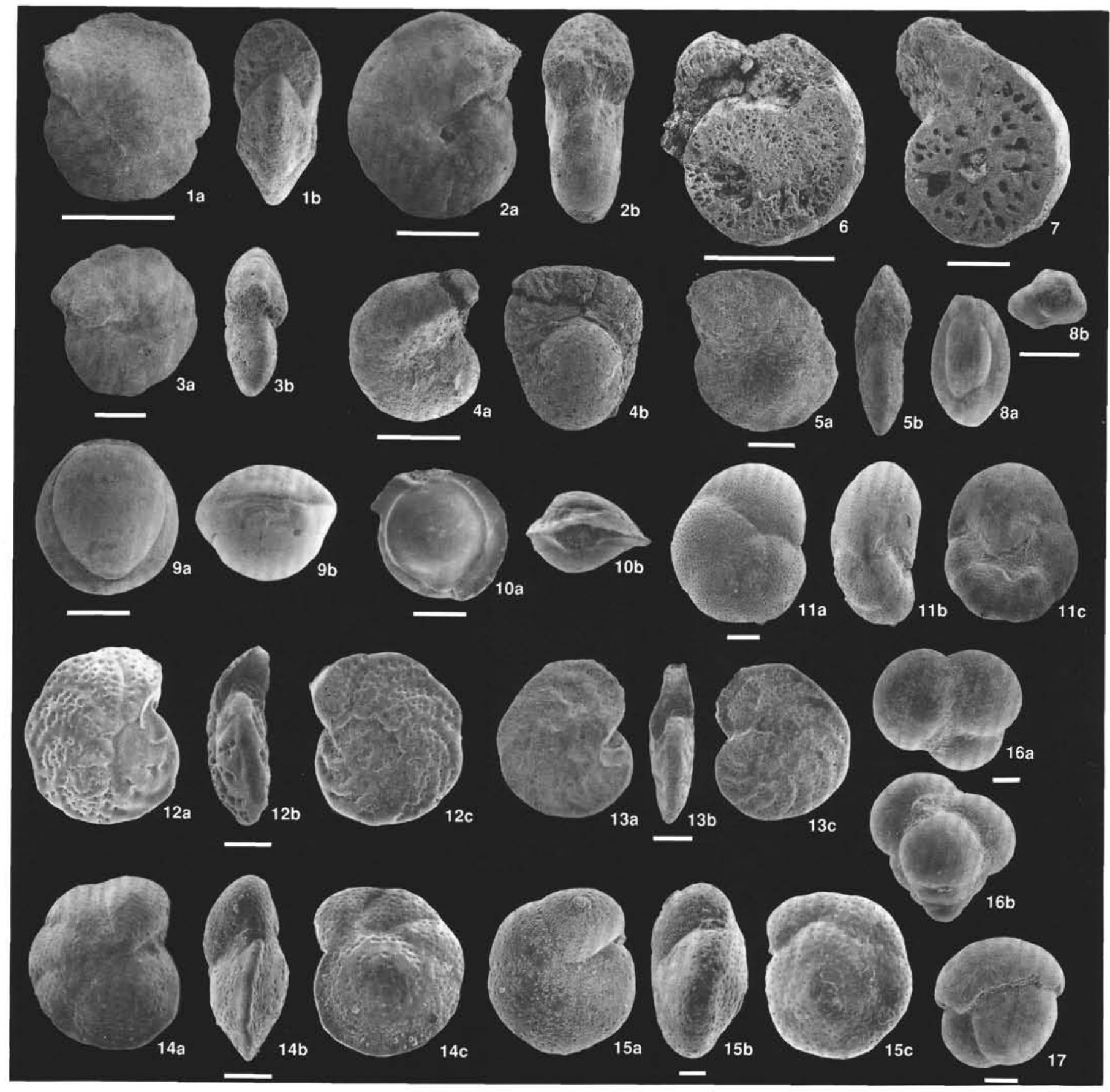

Plate 2. Scale $=100 \mu \mathrm{m} . \quad$ 1a, b. Cyclammina ezoensis, 127-795B-12R-3, 46-50 cm. 2a, b. Cyclammina cancellata, 127-797B-48X-2, 53-57 cm. 3a, b. Cyclammina sp. A, 127-797C-5R-2, 76-80 cm. 4a, b. Cyclammina orbicularis, 127-795B-10R-5, 50-52 cm. 5a, b. Cyclammina pusilla, 127-797B-31X-3, $50-54 \mathrm{~cm}$. 6. Dissected specimen of Cyclammina cancellata, 127-795B-10R-5, 50-52 cm. 7. Dissected specimen of Cyclammina orbicularis, 127-795B-10R5, 50-52 cm. 8a, b. Quinqueloculina sp., 127-797B-35X-4, 50-54 cm. 9a, b. Pyrgo sp. 127-797B-51X-5, 51-53 cm. 10a, b. Pyrgo murrhina, 127-797B$51 \mathrm{X}-5,51-53 \mathrm{~cm}$. 11a-c. Valvulineria masudai, 127-797B-52X-3, 50-54 cm. 12a-c. Cibicidoides wuellerstorfi, 127-797B-40X-2, 35-39 cm. 13a-c. Cibicidoides wuellerstorfi, 127-797B-48X-1, 68-72 cm. 14a-c. Cibicidoides sp. A, 127-797B-51X-5, 51-53 cm. 15a-c. Cibicidoides bradyi, 127-797B-51X5, 51-53 cm. 16a, b. Tosaia hanzawai, 127-797B-51X-5, 51-53 cm. 17. Sphaeroidina japonica, 127-797B-52X-1, 45-49 cm. 


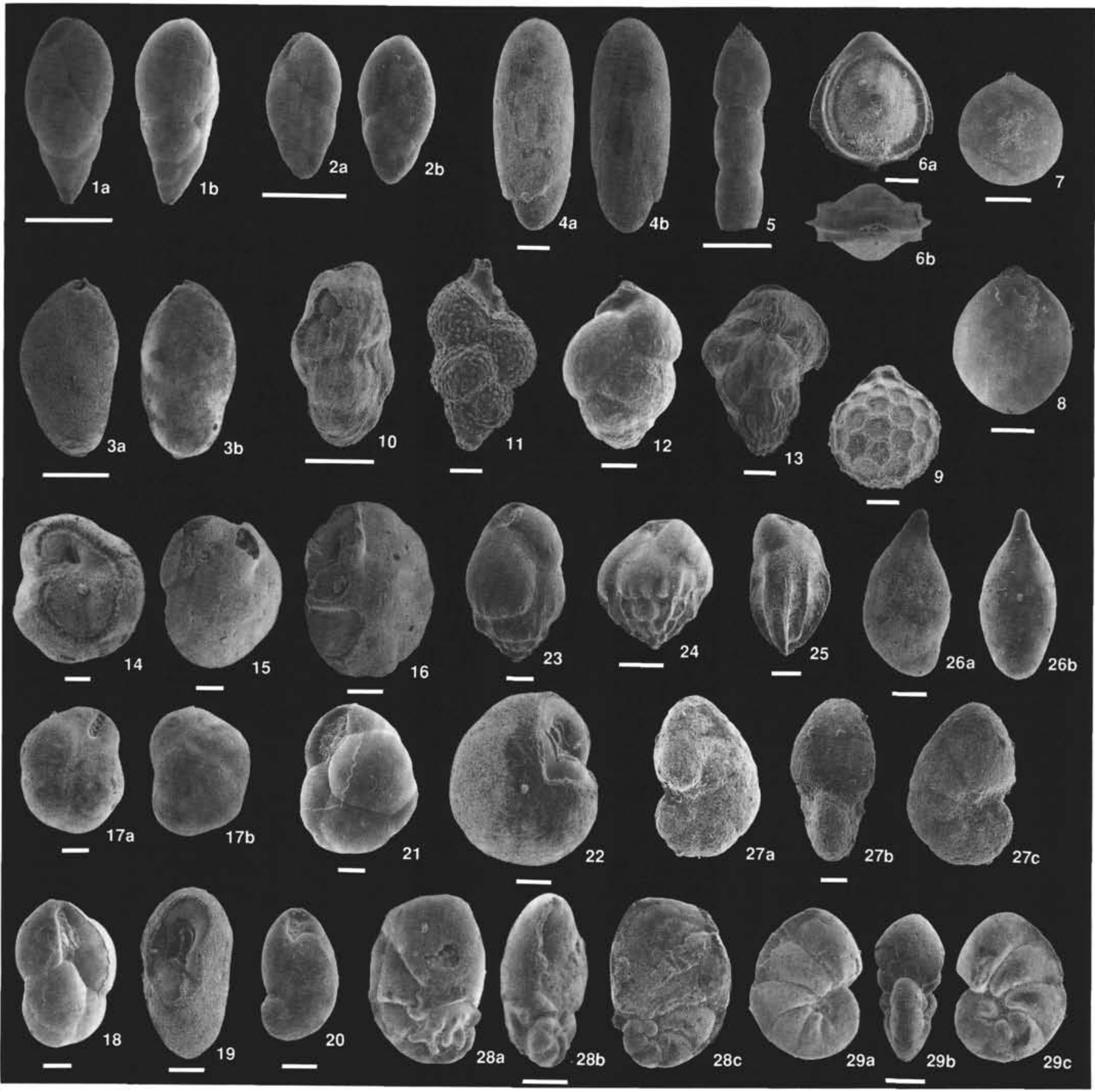

Plate 3. Scale $=100 \mu \mathrm{m} . \quad$ 1a, b, 2a, b. Globobulimina pupoides, 127-797B-52X-3, 50-54 cm. 3a, b. Globobulimina perversa, 127-797B-48X-2, 53-57 cm. 4a, b. Chilostomella oolina, 127-797B-52X-3,50-54 cm. 5. Dentalina sp., 127-797B-51X-5, 51-53 cm. 6a, b. Fissurina orbignyana, 127-797B-51X-3,51-53 cm. 7. Oolina globosa, 127-797B-28X-1, 51-56 cm. 8. Parafissurina sp., 127-797B-51X-5, 51-53 cm. 9. Oolina hexagona, 127-797B-48X-2, 53-57 cm. 10. Uvigerina miocenica, 127-797B-51X-1, 51-53 cm. 11. Uvigerina proboscidea, 127-797B-40X-2, 35-39 cm. 12. Uvigerina cf. modeloensis, $127-797 \mathrm{~B}-$ $52 \mathrm{X}-3,50-54 \mathrm{~cm}$. 13. Trifarina sp. 127-797B-31X-3, 50-54 cm. 14. Globocassidulina globosa s.1., 127-797B-47X-1, 45-49 cm. 15. Islandiella sp., 127-797B-52X-1, 45-49 cm. 16. Islandiella helenae, 127-797B-31X-3, 50-54 cm. 17a, b. Globocassidulina globosa s.1., 127-797B-31X-3, 50-54 cm. 18, 21. Globocassidulina sp. A, 797B-52X-3, 50-54 cm. 19, 22. Islandiella cf. compressa, 127-797B-31X-3, 50-54 cm. 20. Evolvocassidulina kuwanoi, 127-797B-52X-3, 50-54 cm. 23. Bulimina striata, 127-797B-52X-3, 50-54 cm. 24. Bulimina striata, 127-797B-48X-2, 53-57 cm. 25. Bulimina rostrata, 127-795B-29R-2, 116-120 cm. 26a, b. Marginulina sp., 127-797B-51X-5,51-53 cm. 27a-c. Nonionellina labradorica, 127-797B-52X-3,50-54 cm. 28a-c. Nonionella stella, 127-797B-52X-3, 50-54 cm. 29a-c. Nonionella miocenica, 127-797B-51X-3, 51-53 cm. 


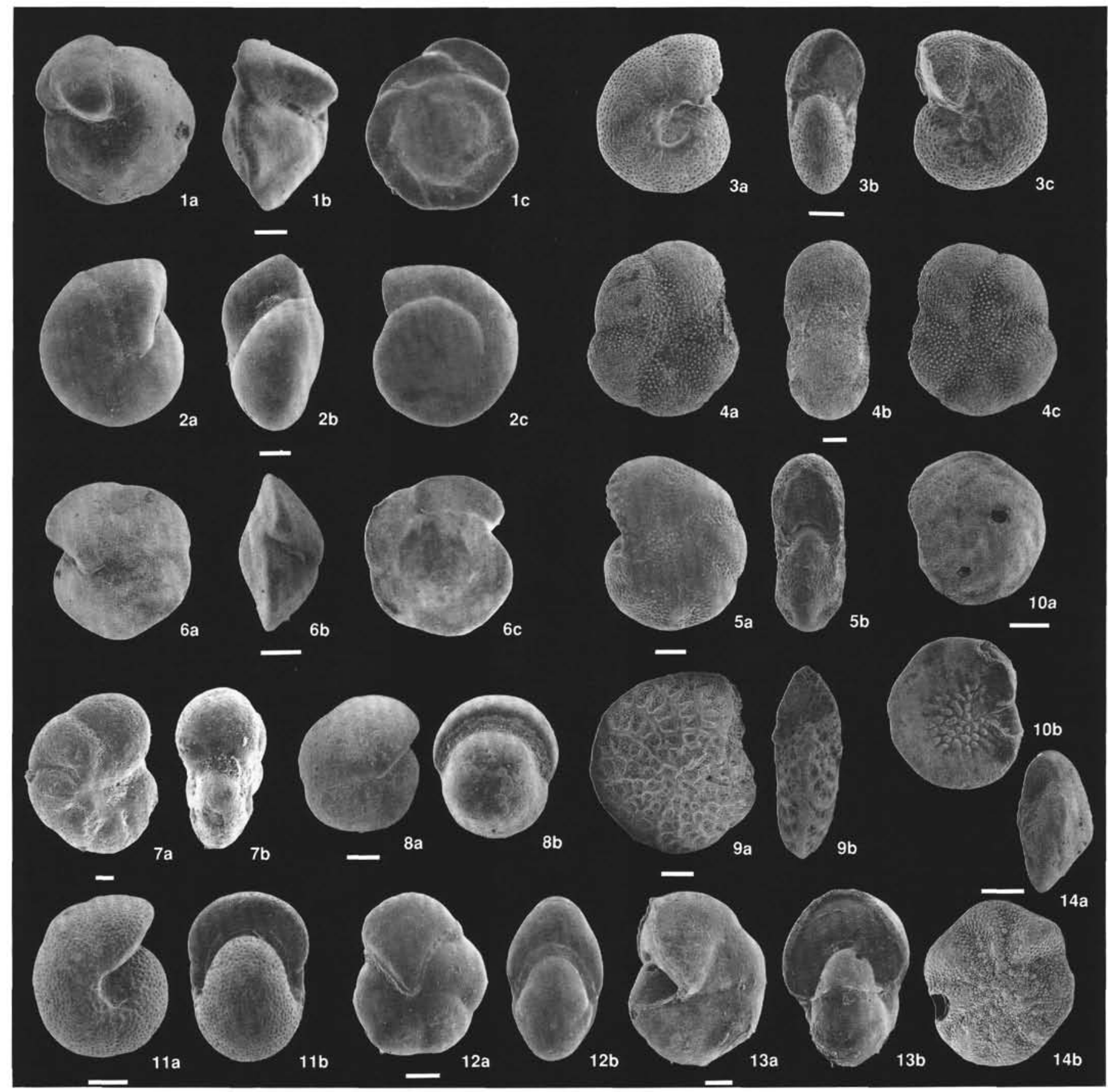

Plate 4. Scale $=100 \mu \mathrm{m} . \quad$ 1a-c. Gyroidina orbicularis, 127-797B-51X-3, 51-53 cm. 2a-c. Gyroidinoides planulatus, 127-797B-51X-5, 51-53 cm. 3a-c. Melonis nikobarense, 127-797B-47X-3,52-56 cm. 4a-c. Elphidium cf. perforatum, 127-795B-29R-2, 116-120 cm. 5a, b. Elphidium subarcticum, 127-797B$31 \mathrm{X}-3,50-54 \mathrm{~cm}$. 6a-c. Oridorsalis umbonatus, 127-797B-52X-1,45-49 cm. 7a, b. Astrononion sp., 127-797B-52X-3, 50-54 cm. 8a, b. Pullenia bulloides, 127-797B-52X-3, 50-54 cm. 9a, b. Elphidium jenseni, 127-797B-31X-3, 50-54 cm. 10a, b. Glabratella subopercularis, 127-797B-31X-3, 50-54 cm. 11a, b. Melonis pompilioides, 127-797B-51X-1,51-53 cm. 12a, b. Pullenia subcarinata, 127-797B-52X-3, 50-54 cm. 13a, b. Pullenia salisburyi, 127-797B-47X$3,52-56 \mathrm{~cm}$. 14a, b. Buccella cf. kuromatsunaiensis, 127-797B-31X-3, 50-54 cm. 